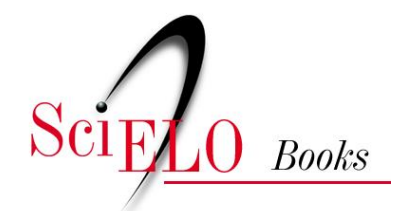

\title{
Trabalhadores, sindicatos e industrialização
}

\author{
Leôncio Martins Rodrigues
}

RODRIGUES, LM. Trabalhadores, sindicatos e industrialização [online]. Rio de Janeiro: Centro Edelstein de Pesquisas Sociais, 2009, 169 p. ISBN: 978-85-99662-99-1. Available from SciELO Books $<$ http://books.scielo.org $>$.

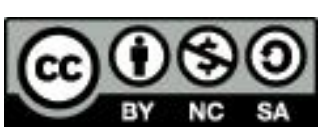

All the contents of this chapter, except where otherwise noted, is licensed under a Creative Commons Attribution-Non Commercial-ShareAlike 3.0 Unported.

Todo o conteúdo deste capítulo, exceto quando houver ressalva, é publicado sob a licença Creative Commons Atribuição Uso Não Comercial - Partilha nos Mesmos Termos 3.0 Não adaptada.

Todo el contenido de este capítulo, excepto donde se indique lo contrario, está bajo licencia de la licencia Creative Commons Reconocimento-NoComercial-CompartirIgual 3.0 Unported. 


\section{BIBLIOTECA VIRTUAL DE CIÊNCIAS HUMANAS}

\section{TRABALHADORES, SINDICATOS E \\ INDUSTRIALIZAÇÃO \\ Leôncio Martins Rodrigues}

centro edelstein de pesquisas sociais www.centroedelstein.org.br 
Leôncio Martins Rodrigues

\section{Trabalhadores, sindicatos e industrialização} Esta publicação é parte da Biblioteca Virtual de Ciências Humanas do Centro
Edelstein de Pesquisas Sociais - www.bvce.org

Copyright (C) 2009, Leôncio Martins Rodrigues

Copyright (c) 2009 desta edição on-line: Centro Edelstein de Pesquisas Sociais Ano da última edição: 1974, Editora Brasiliense

Nenhuma parte desta publicação pode ser reproduzida ou transmitida por qualquer meio de comunicação para uso comercial sem a permissão escrita dos proprietários dos direitos autorais. A publicação ou partes dela podem ser reproduzidas para propósito não comercial na medida em que a origem da publicação, assim como seus autores, seja reconhecida.

ISBN: 978-85-99662-99-1

Centro Edelstein de Pesquisas Sociais

www.centroedelstein.org.br

Rua Visconde de Pirajá, 330/1205.

Ipanema - Rio de Janeiro - RJ

CEP: 22410-000. Brasil

Contato: bvce@centroedelstein.org.br 


\section{SUMÁRIO}

\section{INTRODUÇÃO}

\section{INTRODUÇÃO}

\section{PARTE I: Classe OPERÁria e INDUSTRIALIZAÇÃo.}

Capítulo I: Formação e Desenvolvimento do Sindicalismo

Características gerais da evolução dos sindicatos

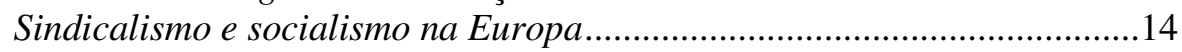

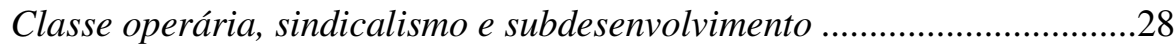

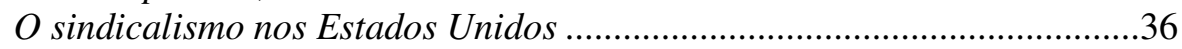

Capítulo II: O Desenvolvimento Europeu e o Proletariado... . .47

A formação do capitalismo na Europa..... . .47

Sociedade de massas e sindicalismo 68

\section{PARTe II: Classe Operária E SOCIEDAde INDUSTRIAL no BRASIL .....86}

Introdução ..... . .86

Capítulo III: Sindicalismo e Ideologias Operárias. . .88

Populismo e classe operária.. . .88

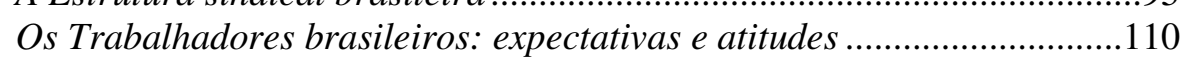

Capítulo IV: O Proletariado e a Industrialização Brasileira ..... .120

O Desenvolvimento econômico: concentração industrial e tecnologia ....120 A Integração dos trabalhadores: autoritarismo e cultura de massas ........125 O Papel da agricultura e do capital estrangeiro... 130

CONCluSÃo: PERSPECTIVAS do Sindicalismo BRASILEIRO 144 AUTORES Citados. .156
A partir da II Guerra Mundial a atenção dos cientistas políticos e sociólogos começa a se voltar para as questões atinentes ao sindicalismo dos países em vias de industrialização. Até então, como era natural, os estudos e pesquisas sobre a classe operária concentravam-se quase unicamente sobre as regiões de velha industrialização, onde tinha surgido um proletariado industrial política e socialmente expressivo. Era relativamente lógico considerar que as orientações que, grosso modo, marcaram a classe operária nas regiões hoje desenvolvidas tenderiam a se reproduzir nos demais países que iniciavam tardiamente o desenvolvimento. Porém, quando o processo de industrialização assumiu maior relevância nesses últimos países e os problemas relacionados à formação de uma sociedade moderna impuseram-se também aí, o pensamento social e político começou a ter condições para uma apreciação mais adequada das orientações operárias e sindicais num contexto político, social e econômico diverso do que cercou a expansão das sociedades europeias e norteamericana. A industrialização nas "áreas periféricas" vem evidenciando que os modos de expressão política e ideológica das camadas trabalhadoras longe de se pautarem por um padrão comum, assumem diferentes formas. $\mathrm{Na}$ verdade, não ignoraram os primeiros teóricos e ativistas do sindicalismo e da classe operária a multiplicidade de correntes ideológicas, de tipos de organização operária e estilos de lideranças vigorantes nos países europeus. Basta atentar, nesse sentido, para as acirradas polêmicas que opuseram anarquistas, marxistas e reformistas no transcorrer da história do movimento operário. Mas a própria virulência das disputas doutrinárias é indicativa de um pressuposto subjacente: o de que, para a classe operária, só haveria um caminho, uma forma de organização adequada, que cada tendência operária julgava representar. A diversidade ideológica ou organizatória era explicada em termos de fatores circunstanciais (capacidade das lideranças, nível de desenvolvimento da consciência de classe, etc.) ou de estágios do desenvolvimento do capitalismo. Julgava-se que a expansão industrial, ou mais precisamente, os modos de expansão, seriam os mesmos em todos os países. Considerava-se, não modelos diferentes mas etapas menos ou mais avançadas de difusão do modo de 
produção capitalista e de industrialização. O exemplo disponível era aquele oferecido pela Inglaterra: o do capitalismo liberal, caracterizado basicamente pelo fato de ser conduzido por uma classe empresarial nacional e de resultar de transformações que se operavam "espontaneamente" no interior do sistema econômico ${ }^{1}$ Tais características, resultantes do impulso industrial burguês e autônomo, sob regime liberal ou autoritário, ofereceram os marcos de expansão e orientação do sindicalismo nos países de antiga industrialização e permaneceram como o pano de fundo teórico para a análise subsequente das orientações da classe operária, análise que era estendida, muitas vezes, para o proletariado dos países subdesenvolvidos.

As semelhanças observadas entre o movimento operário de diferentes países ocidentais que iniciaram mais cedo o processo de industrialização Europa Ocidental, América do Norte e mesmo alguns países da América Latina em que houve, já pelo fim do século passado, a formação de alguns "bolsões industriais" - decorrem do fato de que o sindicalismo nascente é, em larga medida, principalmente uma reação a um meio técnico e econômico surgido com o capitalismo que, em toda parte, é bastante semelhante. Os pequenos grupos de operários, sem possibilidade de pesar nas decisões políticas importantes, reagem antes de tudo a uma situação particular de trabalho. Na medida em que a industrialização prossegue, o comportamento da classe operária não pode mais ser uma simples reação ao meio fabril. Os trabalhadores devem ter em conta outros fatores tais como os efeitos de suas próprias ações sobre a economia e as estruturas políticas, o que implica em considerar, em escala nacional, suas relações com as demais classes e com o sistema de Poder. Não se trata mais de grupos de operários que reagem a um patronato local e disperso mas de uma classe operária (e de suas organizações) que devem estabelecer uma tática e uma estratégia rente a uma classe empresarial relativamente unificada e um sistema de Poder organizado nacionalmente. A partir desse momento, as orientações valorativas e as formas organizatórias adotadas pelo movimento

\footnotetext{
${ }^{1} \mathrm{Na}$ realidade, olhando mais de perto, pode-se perceber que a "versão inglesa" não se reproduziu exatamente na França e na Alemanha, países em que as forças do mercado desempenharam papel menos preponderante. Porém, estas versões não tiveram a mesma capacidade de proselitismo que teve o modelo britânico. Veja-se, a propósito, Andrew SHONFIELD, Capitalismo Moderno, Rio, Zahar, 1968, especialmente pp. 113-4.
}

operário não estão relacionadas apenas ao meio fabril mas as características da sociedade global no seu conjunto.

Em toda parte, a classe operária em formação procurou defender suas condições de trabalho e melhorar sua remuneração. Seria demasiado simples - embora não totalmente errado - incluir as diferentes manifestações de defesa da classe sob a etiqueta de um processo de luta contra o capitalismo. Esta colocação, contudo, tomada esquematicamente, arrisca-se a reduzir o comportamento operário a uma resposta a um único fator (a apropriação privada dos meios de produção) sem especificar as condições concretas em que esta apropriação se realiza e sem levar em devida conta a ação de outras variáveis que se localizam fora do sistema de produção. A análise dessas últimas variáveis assume maior significação quando a classe operária adquire maior peso na vida social do país. Quando a produção industrial passa a ser o setor que responde pela dinâmica do sistema econômico no seu conjunto, os problemas da sociedade passam a ser, em larga medida, os problemas da indústria. A continuação do desenvolvimento não depende apenas das decisões particulares de investimento dos dirigentes industriais mas depende também de outras forças sociais não diretamente envolvidas no sistema produtivo. Especificamente, a partir de certa etapa, a expansão industrial envolve as estruturas de Poder, os sistemas políticos e diferentes instituições que podem obstaculizar ou favorecer o crescimento econômico. As reações dos trabalhadores industriais passam a ser largamente influenciadas não apenas pelo meio fabril como também pelas características do sistema político, pelo tipo de elite que dirige o desenvolvimento, pelos valores dominantes, etc. Suas orientações não podem ter como referência apenas os grupos empresariais.

A análise comparativa do movimento operário em diferentes países, e em diferentes momentos históricos, revela a multiplicidade de orientações ideológicas e políticas, estilos de liderança, formas de ação, graus de radicalismo da classe operária, etc.. Em termos de uma visão voluntarista, as transformações observadas nas formas de comportamento sindical e político da classe são amiúde interpretadas como uma "evolução" do proletariado, medida geralmente a partir do grau de intervenção da classe no processo político, do nível organizatório, da capacidade reivindicativa e de pressão sobre o sistema econômico e sobre as estruturas de Poder. 
Ao longo da história da industrialização, este tipo de visão do movimento operário, apesar da teleologia implícita, encontrava certo fundamento no meio social. $\mathrm{O}$ avanço da indústria trazia consigo o aumento do número de operários, sua concentração em grandes fábricas e nos centros urbanos, propiciando condições mais favoráveis para o fortalecimento das associações e partidos operários.

Obviamente, dado seu caráter voluntário, o movimento associativo operário depende da coesão da classe, da solidariedade entre seus membros e também da experiência e maturidade alcançadas pelas lideranças, isto é, de elementos "subjetivos". Na medida em que a obtenção e consolidação de certas reivindicações da classe resultam de um processo de luta na qual os trabalhadores, individual e coletivamente, medem o resultado de seus esforços e de seus combates, não é incorreto, neste sentido, falar de uma "evolução" da classe, se com isso se quer entender o processo pelo qual os trabalhadores avaliam suas ações e as lideranças refletem sobre a tática aplicada e sobre seus resultados.

Entretanto, as transformações operadas nas orientações da classe não resultam unicamente dos elementos subjetivos envolvidos, quais sejam, a solidariedade grupal, a experiência das lideranças, o "espírito de luta", etc.. É possível relacionar certas ações e atividades dos trabalhadores com a natureza do processo de industrialização e outras características da sociedade e do sistema político. Numerosos estudos evidenciaram o relacionamento entre determinadas formas de ação operária com o tipo de organização do trabalho e de administração das empresas, com o lugar que a classe ocupa no interior da sociedade, com a forma de relacionamento com o Poder e com as demais classes sociais, etc. ${ }^{2}$.

Mais detalhadamente, pode-se encontrar, por exemplo, uma relação entre o tipo de atividade econômica e as características dos grupos operários aí empregados e a maior ou menor incidência de movimentos grevistas ${ }^{3}$.

${ }^{2}$ Cf. A. TOURA1NE e B. MOTTEZ, "Classe Operária e Sociedade Global", in: G. Friedmann e P. Naville (eds.), Tratado de Sociologia del Trabajo, México, Fondo de Cultura Económica, 1963, II vol. Tradução brasileira in: Leôncio Martins Rodrigues (org.) Sindicalismo e Sociedade, S. Paulo, Difusão Européia do Livro, 1968.

${ }^{3}$ Por exemplo, é possível estabelecer uma correlação entre o tipo de indústria e a maior ou menor propensão para a greve. Cf. Clark KERR e Abrahan SIEGEL, "The Interindustry
Outras pesquisas evidenciaram que o meio social de recrutamento dos trabalhadores (meio rural, meio urbano, etc.) influenciam as atitudes com relação à empresa, ao trabalho fabril ${ }^{4}$, às organizações sindicais, etc. ${ }^{5}$. Sabe-se, por outro lado, que as concentrações mineiras tendem a favorecer a emergência de uma "subcultura operária" e propiciar um alto grau de solidariedade e de espírito comunitário entre os trabalhadores, ${ }^{6}$ assim como formas extremadas de conflito.

Mas o movimento operário no seu conjunto, considerado em escala nacional, não deve ser pensado apenas como reação a uma situação de trabalho ou a um meio técnico. As orientações políticas e sindicais dos trabalhadores dependem, em medida difícil de ser determinada, de certas características mais gerais do processo de industrialização e da sociedade global. São elas que permitem explicar a variedade de formas ideológicas e de orientações sindicais e políticas da classe nos diferentes países, apesar das muitas similitudes de situações técnicas e econômicas encontradas nas sociedades industriais.

Cumpre considerar, de um lado, a natureza do processo de industrialização (e de formação da classe) e, de outro lado, as características das sociedades nacionais no interior das quais a industrialização se realiza. Se a formação da classe operária, enquanto categoria social, e sua composição profissional resultam de fatores técnicos e econômicos (a tecnologia industrial e o modo de produção capitalista), os valores e ideologias que orientam suas ações parecem determinados pelo modo

Propensity to Strike - An International Comparison”. in: R. Dubin, A. Kornhauser e A. Ross (eds.), Industrial Conflict, Nova York, McGraw Hill, 1954.

${ }^{4}$ Touraine e Ragazzi, em pesquisa realizada com trabalhadores de origem agrícola de uma empresa automobilística francesa, mostram que esses trabalhadores são orientados por objetivos de natureza econômica, o que acarreta uma fraca integração ao meio social e profissional de trabalho. A. TOURAINE e O. RAGAZZI, Ouvriers d'Origine Agricole, Paris, Seuil, 1961.

${ }^{5}$ Lipset e Gordon mostram a influencia da origem operária ou não operária na participação sindical dos trabalhadores. Ver: S. M. LIPSET e Joan GORDON, "Mobility and Trade Union Membership", in: R. Bendix e S. M. Lipset (eds.) Class, Status and Power, The Free Press of Glencoe, $1961,5^{\mathrm{a}}$ ed.

${ }^{6}$ Cf. a pesquisa comparativa sobre o comportamento e atitudes operárias em Lota e Huachipato in: Torcuato DI TELLA, Lucien BRAMS, Jean-Daniel REYNAUD e Alain TOURAINE, Sindicato y Comunidad, Buenos Aires, Editorial del Instituto, 1967. 
concreto de embricamento do processo técnico-econômico com o meio préindustrial. Para fins heurísticos podem-se distinguir dois conjuntos de fatores determinantes: de um lado, as particularidades do desenvolvimento econômico, em especial o tipo de tecnologia disponível, que por sua vez afetará o volume e a qualificação da mão de obra, o montante e as formas de remuneração do trabalho, o modelo de relações industriais; de outro lado, as particularidades do meio social (entendido em sentido amplo) no interior do qual se realiza a industrialização. Introduz-se aqui, como variáveis relevantes, o papel das instituições, dos grupos e camadas préindustriais, dos sistemas axiológicos, do sistema político, etc..

As formas concretas assumidas pelo sindicalismo e pelo movimento operário nos diferentes países resultam da interação desses dois conjuntos de variáveis que dizem respeito, de um lado, à especificidade do processo econômico e técnico, com sua lógica própria, e de outro, às formações nacionais pré-industriais. Isto implica considerar como variáveis importantes não apenas o sistema de propriedade, a forma privada de apropriação do excedente e os efeitos dos procedimentos técnicos sobre o comportamento operário, mas o contexto social, político e cultural global no interior do qual a industrialização se efetua. As razões determinantes das orientações políticas do proletariado industrial parecem decorrer, assim, de um dado modo de formação da sociedade industrial e da experiência vivida pela classe nesse processo.

Diferentes pesquisas mostraram que as orientações ideológicas do sindicalismo, o radicalismo dos conflitos, certas formas de consciência operária, enfim, o comportamento geral da classe face ao poder econômico e político, estão relacionados a numerosos fatores de natureza tecnológica, econômica, política e social: grupos que dirigem o processo de desenvolvimento ${ }^{7}$, sistemas de valores da sociedade $^{8}$, setor econômico, categoria profissional $^{9}$, etc..

${ }^{7}$ Cf. C. KERR, J. DUNLOP, F. HARBINSON e Ch. MYERS, Industrialismo e Sociedade Industrial, Rio, Fundo de Cultura, 1963.

${ }^{8}$ S. M. LIPSET, The First New Nation, Nova York, Anchor Books, 1967 (1•a ed.: 1963), especialmente capítulo 5: "Trade Unions and the American Values System". Tradução brasileira: in: Leôncio Martins Rodrigues (org.) Sindicalismo e Sociedade. S. Paulo, Difusão Européia do Livro, 1968.

${ }^{9}$ Cf. A. TOURAINE, La Conscience Ouvrière, Paris, Seuil, 1966.
Não teríamos condições de apreciar de modo sistemático a complexidade de situações sindicais e operárias nos diferentes países. Aqui estamos interessados apenas em tentar isolar os principais fatores relacionados à formação do capitalismo europeu e que parecem significativos para a análise das formas de ação e ideologia operárias. Nas páginas que se seguem, tentaremos pôr em relevo certos aspectos do surgimento e consolidação do sindicalismo nas sociedades desenvolvidas do Ocidente. Não se pretende traçar uma história da classe operária nesses países mas destacar elementos que facilitem a compreensão das condutas operárias que se formam em outros contextos sociais, especificamente no Brasil. Assim, a I Parte deste trabalho ocupa-se com o sindicalismo e a classe operária em outros países, especialmente na Europa Ocidental. A II Parte trata unicamente do sindicalismo e do movimento operário no Brasil. 


\section{PARTE I}

\section{CLASSE OPERÁRIA E INDUSTRIALIZAÇÃO}

\section{Capítulo I \\ FORMAÇÃO E DESENVOLVIMENTO DO SINDICALISMO}

\section{Características gerais da evolução dos sindicatos}

Malgrado os diferentes caminhos por que passou a evolução do movimento associativo operário e a diversidade de ideologias que envolveram a origem do sindicalismo europeu, é possível destacar alguns elementos comuns que, em menor ou maior grau, estiveram presentes nas fases iniciais de sua formação. Para os fins de exposição conviria tratar separadamente as transformações sofridas pelos sindicatos enquanto organizações e as mudanças operadas nos sistemas de valores que inspiraram sua ação.

\section{Os Tipos de Organização Sindical}

Do ponto de vista organizatório, o processo de expansão sindical foi relativamente semelhante. Em todos os países de velha industrialização, os grupos de trabalhadores que primeiro se organizaram profissionalmente foram aqueles em que os componentes artesanais do trabalho se mantiveram no capitalismo industrial. As primeiras associações operárias foram formadas por ex-artesãos, isto é, por trabalhadores profissionalmente qualificados (marceneiros, pedreiros, pintores, etc.). Não se tratava mais de trabalhadores independentes mas de assalariados submetidos à disciplina das oficinas e à lei do proprietário. Contudo, nesta fase de expansão do capitalismo, as modificações ocorridas afetavam mais a situação social e o status jurídico desses grupos do que o modo e a técnica de organização do trabalho.

Em outras palavras: do ponto de vista técnico, o tipo de tarefa e o modo de realizá-la não se tinham modificado substancialmente. Em numerosos casos, o trabalhador era ainda proprietário de suas ferramentas (pouco especializadas e polivalentes) porém não era mais o proprietário do resultado de seu trabalho. Este aspecto merece ser ressaltado uma vez que influenciará as ideologias do sindicalismo e do movimento operário. Abrangendo inicialmente grupos de ex-artesãos transformados em assalariados, as primeiras associações operárias se constituíram geralmente em torno de um mesmo ofício e não da empresa. Trata-se de um sindicalismo de trabalhadores "profissionais" que agrupava operários de uma mesma profissão ${ }^{1}$.

Trabalhadores não qualificados e mulheres não tinham acesso a essas associações uma vez que não tinham o domínio de um ofício. $O$ sindicalismo de ofício ${ }^{2}$ era caracterizado por forte exclusivismo profissional que as ideologias igualitárias mal conseguiam atenuar. O enquadramento das camadas operárias de baixa qualificação - normalmente os trabalhadores das novas indústrias - deu-se mais tardiamente com a emergência e a expansão do chamado sindicalismo de indústria. Este agrupou trabalhadores não mais segundo o ofício mas segundo o ramo industrial (indústria do aço, do automóvel, etc.). O critério de arregimentação deixou de ser o tipo de tarefa e passou a ser o setor de produção. Geralmente, a organização sindical por indústria enquadrou trabalhadores não qualificados, ou semiqualificados, uma vez que a

\footnotetext{
${ }^{1}$ Para a formação do sindicalismo na Inglaterra e na França, veja-se: G.D.H. COLE, Short History of the British Working Class, Londres, George Allen and Unwin. 1945; Sidney e Beatrice WEBB, The History of Trade-Unionism, Londres, Longmans Green and Co., 1950 (19 ed.: 1894) e mais recentemente Henry PELLING, A History of British Trade-Unionism. Londres, Pelican Books, 1963; para a França, veja-se: Robert BOTHEREAU, Histoire du Syndicalisme Français, Paris, Presses Universitaire de France, 1946; Jean MONTREUIL, Histoire du Mouvement Ouvrier en France, Paris, Aubier, 1946; Edouard DOLLEANS, Histoire du Mouvement Ouvrier, Paris, Armand Colin, 1953, III vols. Para um estudo conjunto da formação do sindicalismo na Inglaterra e na França, consulte-se André PHILIP, Trade Unionisme et Syndicalisme, Paris, Fernand Aubier, 1936.

${ }^{2}$ Os sindicatos de ofício procuravam firmar-se principalmente através do controle de aprendizado, fixando o tempo de duração de aquisição de um ofício, o número de aprendizes, etc.; "A tradição de aprendizado era herdada dos regulamentos das guildas e de uma imposição estatutária. Em meados do Século XIX estes suportes tinham há muito desaparecido. O sistema sobrevivia através do costume mantido pelos artesãos e aceito pelos empregadores. O primeiro objetivo dessas sociedades (sindicatos de ofício) era transformar este costume em leis universais e uniformes, de modo a obter o firme controle sobre o tamanho da força de trabalho". H.A. CLEGG, Alan FOX e A.F. THOMPSON, A History of British Trade-Unionism Since 1889, Oxford, Clarendon Press, 1964, pág. 5.
} 
extensão do sistema de produção em série agia no sentido da desqualificação do trabalho operário.

A predominância do sindicalismo industrial sobre o sindicalismo de ofício assinalou igualmente modificação nas táticas e nas formas de luta das associações operárias. Ela correspondeu, de outro ponto de vista, ao que alguns autores têm chamado de passagem de um sindicalismo de minorias militantes para um sindicalismo de massas. Pelo momento, basta assinalar que se assiste a um deslocamento relativo da primazia das ações baseadas no local de trabalho, das ações econômicas para as ações políticas, para a pressão parlamentar.

$\mathrm{Na}$ Europa Ocidental, a predominância do sindicalismo industrial coincidiu, no plano político, com a formação dos grandes partidos operários de massa (e emergência da socialdemocracia) com capacidade de atuação política e de pressão sobre o Parlamento dos países democráticos do Ocidente. Do prisma das motivações das ações operárias, isto significa que o sindicalismo deixou de ser uma simples reação a situações criadas pelo meio fabril para se preocupar, na medida em que aumentou seu poder de intervenção, com os problemas gerais de funcionamento do sistema econômico e social global. Touraine e Mottez, enfatizando as formas de ação operária, denominam esta transição de passagem de um sindicalismo de oposição para um sindicalismo de controle

Muitas razões contribuíram, nas primeiras fases da industrialização para o avanço associativo dos antigos artesãos em comparação com o dos novos trabalhadores fabris. À parte o fato de estar a organização industrial do trabalho nos seus primórdios, outras razões facilitaram a rápida arregimentação das camadas de trabalhadores qualificados. Já possuíam elas uma consciência profissional e uma tradição organizatória vindas das antigas corporações de ofício (guildas, capelas, etc.) que facilitaram a organização profissional sob as novas condições surgidas com a expansão do capitalismo ${ }^{4}$. Por outro lado, os salários mais elevados e estáveis dos

\footnotetext{
${ }^{3}$ A. TOURAINE e B. MOTTEZ, op. cit.

${ }^{4}$ Certas normas e costumes das associações corporativas operárias continuaram a vigorar já em pleno capitalismo. Veja-se, por exemplo, em E.J. HOBSBAWM, Rebeldes Primitivos (Rio, Zahar, 1970) a descrição das práticas secretas de adesão às "irmandades profissionais" (Cap. "O Ritual nos Movimentos Sociais"). O mesmo autor, em outra obra, mostra a
}

grupos qualificados, ao lhes permitir uma situação financeira mais cômoda, facilitava a cotização para as diferentes modalidades associativas (caixas de assistência mútua, uniões, etc.). Ademais, os grupos de artesãos geralmente possuíam nível de escolarização mais elevado do que os trabalhadores não qualificados do setor fabril, recrutados recentemente da agricultura e, na sua maioria, analfabetos.

A evolução posterior da industrialização, contudo, favorecerá a expansão dos sindicatos de trabalhadores semiqualificados das novas fábricas e a organização por indústria. Os sindicatos de ofício não desapareceram, mas - apesar de abrirem suas portas para os trabalhadores não qualificados - tornaram-se de importância secundária ante os grandes sindicatos industriais. Os primeiros, ameaçados constantemente pelo progresso técnico, tornaram-se, algumas vezes, conservadores e dominados por um exclusivismo de tipo corporativista.

Ainda do ponto de vista organizatório, cumpriria mencionar outro tipo de organização sindical que vigorou em alguns países ocidentais como a Inglaterra: os chamados "sindicatos gerais", agrupando trabalhadores de várias profissões ou ramos industriais, geralmente não qualificados, que não encontravam lugar nos sindicatos de operários qualificados. Os "sindicatos gerais" surgiram habitualmente com objetivos revolucionários, buscando organizar todos os trabalhadores, independentemente da profissão ou setor econômico, na luta contra o capitalismo. De acordo com Hobsbawm, este tipo de união não pode ser analisado segundo as divisões clássicas do sindicalismo. "De fato, os sindicatos gerais preencheram, às vezes simultaneamente, três funções bastante diferentes: como 'sindicatos de classe' (class-unions), tentaram unir todos os empregados contra os

persistência de uma instituição indicativa da consciência profissional e corporativa: a prática das viagens e deslocamentos de trabalhadores, amparados e albergados pelas associações das categorias profissionais. Ver: "The Tramping Artisans", in: Labouring Men. Studies in the History of Labour, Basic Books. Inc., Publisher, Nova York, 1964. O sistema era usual também na Europa continental. Na França, as sociedades chamadas compagnonnages, destinadas a manter ou melhorar a situação de seus membros pelo controle do emprego e de certas regras referentes às condições de trabalho, favoreciam as viagens de artesãos de uma cidade para outra à procura de emprego ou de novos conhecimentos profissionais. Os recémchegados a uma cidade eram alojados e alimentados pela associação. Esta, além disso, arrumava-lhes uma colocação ou os encaminhava a outra cidade. Ver G.P.JONES. Worker Abroad, Londres, Thomas Nelson and Sons, 1939, cap. "From the gilds to the revolution". 
empregadores, geralmente sob inspiração socialista ou revolucionária. Como 'sindicatos de trabalhadores não qualificados' (labourers unions) tentaram oferecer uma efetiva organização para trabalhadores sem condições de integrar o sindicalismo de ofício ortodoxo, ou dele excluídos. Como 'sindicatos residuais' (residual unions), finalmente, organizaram trabalhadores não efetivamente cobertos por outros sindicatos"

Os sindicatos gerais surgiram frequentemente em oposição aos sindicatos de ofício quando estes se tornaram conservadores e preocupados essencial ou exclusivamente com a defesa dos interesses profissionais específicos da categoria de trabalhadores qualificados que representavam.

Buscando sindicalizar uma mão de obra de baixa qualificação, pouco estável no emprego, os "sindicatos gerais" tenderam a recorrer a táticas agressivas, de ação direta. Assim, por exemplo, nos EUA, o Industrial Workers of the World (IWW) se lançou à organização de trabalhadores imigrantes de baixa qualificação (têxteis, particularmente) da indústria da costa Atlântica e, depois, dos trabalhadores agrícolas do Oeste, onde se registraram alguns dos mais violentos conflitos da história do movimento operário nos $\mathrm{EUA}^{6}$. Na Inglaterra, a partir de 1890, o "novo sindicalismo", conflitando com os sindicatos de ofício, logrou êxitos mais duradouros ao organizar os doqueiros e os operários da indústria do gás em sindicatos "profissionalmente variados". Observa Pelling que o sindicato do gás chegou a abranger inclusive trabalhadores "que nada tinham a ver com a indústria do gás, como por exemplo os da manufaturas de lã do West Riding"7 .

Os sindicatos gerais, na medida em que agiam, no dizer de Hobsbawm, como "sindicatos de classe", com objetivos revolucionários, não conseguiram sobreviver apesar de alguns êxitos iniciais. Em outros

${ }^{5}$ E.J.HOBSBAWM, Labouring Men, cap. "General Labour Unions in Britain: 1889-1914”, ix 179. Ver também G.D.H. COLE, An Introduction to Trade-Unionism, George Allen \& Unwin Ltd., 1953, cap. "Types of Trade Unions".

${ }^{6}$ Para a história do sindicalismo norte-americano. cf.: Joseph RAYBACK, A History of American Labor, The MacMillan Co., 1959; Florence PETERSON, American Labor Unions, Nova York, Harper and Brother Publishers, 1952; Robert MARJOLIN, L'Évolution du Syndicalisme aux États-Unis, Paris, Librairie Felix Alcan, 1936; Henry PELLING, El Sindicalismo Norteamericano, Madrid, Tecnos, 1961; Pierre WALINE, Les Syndicats aux Etats-Unis, Paris, Armand Colin, 1951

${ }^{7}$ Henry PELLING, A History of British Trade-Unionism, Londres Penguim Book, 1963, p. 101. casos, orientando-se para a via da negociação coletiva, alguns deles chegaram a se consolidar, como por exemplo, o Transport and General Union, que se transformou no maior sindicato da Inglaterra.

\section{As ideologias operárias}

Observada do ponto de vista ideológico, a evolução do sindicalismo nos diferentes países apresenta igualmente elementos de similitude. Malgrado as concepções conflitantes e as divergências existentes entre as numerosas correntes ideológicas do movimento operário, o sindicalismo começou, em toda parte, orientado geralmente por ideologias de reformulação da ordem capitalista ${ }^{8}$. O conteúdo de tais concepções variou no tempo e no espaço mas continha sempre a ideia de uma alternativa coletivista ou socialista a ser alcançada através de cooperativas de produção e de consumo, ou de uma sublevação revolucionária do proletariado. O movimento operário do começo do século passado oscilou entre as duas vias ${ }^{9}$. Ambas expressavam a rejeição dos setores politicamente ativos da classe operária a um modo de produção e de organização social que se consolidava com os progressos do maquinismo. Como elemento central dessas concepções estava a figura do operário como produtor, como único criador de riquezas. $\mathrm{O}$ conceito de trabalho produtivo supunha trabalho manual, transformação e contacto direto com um objeto material. Embora, provavelmente, as ideologias de "negação do sistema" não alcançassem o conjunto da força de trabalho, os núcleos de operários qualificados, política ou sindicalmente organizados, eram fortemente movidos por uma percepção "classista" da sociedade, dividida entre os que

8 “... todos os movimentos operários em nossos países ocidentais e nos países subdesenvolvidos começaram sempre por um período de ideologia revolucionária. As formas ideológicas podem ter variado. Pode-se distinguir tendências opostas, anarquistas e estatizantes, pode-se encontrar traços conservadores de apego ao passado, um mito de retorno à Idade do Ouro sob uma aparência progressista. Porém, essas diferenças são basicamente acessórias. O essencial é a violenta impugnação da ordem estabelecida e a esperança, igualmente violenta, de transformar imediatamente o mundo". Michel CROZIER, "Sociologia do Sindicalismo", in: G. Friedmann O. P. Naville (eds.): Tratado de Sociologia del Trabajo, II vol. p. 190. (Tradução brasileira in: Leôncio Martins Rodrigues (org.), Sindicalismo e Sociedade).

${ }^{9}$ Até 1850 , e até algum tempo depois, "só houve dois caminhos possíveis de avanço até o socialismo... Um era a revolução violenta; o outro, a ação cooperativa voluntária, separada do Estado". G.D.H. COLE, História del Pensamiento Socialista, vol. I, "Los Precursores", México, Fondo de Cultura Económica, 1964, 3, ed. p. 313. 
"produzem" e os "exploradores", burgueses e aristocratas. O ideal de uma ordem social organizada em outras bases, vinculava as reivindicações fabris imediatas à ideia de uma sociedade futura "sem amos nem senhores", dirigida pelos próprios produtores.

O ideal que animava os núcleos ativos de trabalhadores foi essencialmente um "socialismo de produtores". A nova sociedade seria baseada na gestão direta dos meios de produção pelos próprios trabalhadores. No universo ideológico e doutrinário do movimento operário desta fase, a problemática da estatização e do desenvolvimento econômico não ocupava um lugar proeminente. $O$ planejamento, vagamente concebido, era visto em termos de atendimento das necessidades da população trabalhadora, de distribuição de riquezas e não em termos de crescimento econômico. A ideia de planejamento estatal centralizado - que posteriormente, sob influência stalinista identificou-se com a própria essência do socialismo - não fazia parte do elenco de alternativas operárias para o regime capitalista.

Estes aspectos do movimento operário foram comuns a todas as áreas que se industrializaram mais cedo: Europa, América do Norte e mesmo em alguns países latino-americanos em que ocorreu, pelo fim do século passado e começos do atual, a constituição de núcleos industriais e o aparecimento de grupos operários de alguma importância, como na Argentina, Chile, Uruguai e região sul do Brasil.

\section{Sindicalismo e socialismo na Europa}

Apesar dos aspectos comuns apontados, há certas características relacionadas ao sindicalismo, ao socialismo e ao movimento operário que, apesar de serem amiúde considerados como resultado da evolução natural da classe, só ocorreram nos países europeus de velha industrialização. O primeiro deles refere-se à formação dos grandes partidos socialistas, trabalhistas ou comunistas de base social operária; o segundo, à estreita vinculação entre esses partidos operários e as organizações sindicais; o terceiro, à extensão e influência dos trabalhadores industriais, enquanto classe, na vida política, social e cultural dos respectivos países ${ }^{10}$. Esses aspectos mostram uma forma

${ }^{10}$ A ênfase nesses aspectos não implica em aceitar a imagem, que nunca correspondeu à realidade histórica, de uma classe operária coesa, monoliticamente orientada por objetivos de mobilização dos trabalhadores, em termos de classe, que marcou profundamente as sociedades europeias e que, em certa medida, perdura até hoje. Indicam também uma influência do proletariado na vida nacional dos respectivos países sem comparação com qualquer outra região.

Fora da Europa Ocidental, de um modo geral, não houve a formação de partidos operários de massa de ideologia socialista, associados ao movimento sindical e com tão forte influência sobre as estruturas de Poder e sobre a vida econômica das sociedades nacionais.

Os aspectos que cercaram o aparecimento da classe operária europeia, quando cotejados hoje com os de outros países, parecem demonstrar que o modelo que parecia universal - espécie de espelho no qual o proletariado de todo o mundo enxergava seu futuro - resultaram da conjunção de circunstâncias históricas particulares que dificilmente poderão se repetir. Em lugar de representarem uma etapa indicam um tipo de expressão política da classe operária vinculada a certas características da formação do capitalismo europeu que se tratará de especificar no capítulo seguinte.

Já vimos que, em toda parte, o movimento operário do Século XIX e inícios do Século XX é fortemente marcado por doutrinas variadas de rejeição da ordem capitalista. Correntes socialistas existiram sempre no interior do movimento sindical, assim como núcleos de intelectuais socialistas que frequentemente desempenharam um papel importante na formação do movimento sindical. No entanto, fora dos países industrializados da Europa, raramente ultrapassaram a situação de oposições sindicais minoritárias, ou de grupos de propaganda, não chegando a partilhar das responsabilidades do Poder. Geralmente, esses núcleos declinaram com o avanço da industrialização e, paradoxalmente, com a própria consolidação dos sindicatos, sem terem podido transformarse em partidos de massa. Na Europa, pelo contrário, a extensa difusão das ideologias socialistas entre os diferentes grupos de trabalhadores levou à formação dos grandes partidos socialistas de base operária que se tornaram participantes do jogo do poder e, algumas vezes, do governo.

revolucionários. Não implica igualmente em negar a influência de correntes não socialistas entre os trabalhadores, mas sim em afirmar que as características acima foram dominantes, entre os trabalhadores europeus, numa escala sem precedente no mundo. 
A expansão do movimento socialista e sindical na Europa Ocidental começou, de fato, a partir da última década do século passado com a extensão do sufrágio eleitoral e a abolição das legislações antissocialistas. Assim, já em 1905, a socialdemocracia alemã registrava 400 mil aderentes; em 1909, 633 mil, chegando a cerca de um milhão em 1912. O Partido Trabalhista Inglês, com 375 mil membros no começo do século, passou a 900 mil em 1904 e a 1.430 mil em 1920; o número de cotizantes do Partido Operário belga passou de 117 mil, em 1905, a 223 mil em 1911.

Proporção de socialistas eleitos nos parlamentos ${ }^{11}$

\begin{tabular}{|l|c|c|c|l|l|c|}
\hline País & $\%$ & Ano & $\%$ & \multicolumn{1}{|c|}{ Ano } & $\%$ & Ano \\
\hline Suécia & 1,7 & $(1902)$ & 5,7 & $(1905)$ & 34,2 & $(1911)$ \\
\hline Bélgica & 21,6 & $(1900)$ & 18,1 & $(1904)$ & 34,2 & $(1912)$ \\
\hline Alemanha & 14,1 & $(1898)$ & 10,8 & $(1907)$ & 27,7 & $(1912)$ \\
\hline & 20,2 & $(1903)$ & & & & \\
\hline Dinamarca & 12,0 & $(1901)$ & 21,1 & $(1906)$ & 21,06 & $(1910)$ \\
\hline Holanda & 7,0 & $(1901)$ & 7,0 & $(1905)$ & 18,0 & $(1913)$ \\
\hline França & 6,3 & $(1898)$ & 8,9 & $(1906)$ SFIO* & 12,6 & $(1910)$ \\
\hline & 8,7 & & & & 17,8 & $(1914)$ \\
& & & & & & SFIO \\
\hline Áustria & 3,1 & $(1901)$ & 16,8 & $(1904)$ & 15,8 & $(1911)$ \\
\hline Itália & 6,3 & $(1900)$ & 5,5 & $(1904)$ & 9,8 & $(19130$ \\
\hline & & & 8,4 & $(1909)$ & & \\
\hline Suíça & 4,2 & $(1902)$ & 1,2 & $(1905)$ & 7,8 & $(1911)$ \\
\hline Grã-Bretanha & 0,2 & $(1900)^{* *}$ & 4,5 & $(1906) P T * * *$ & 6,26 & $(1912)) P T$ \\
\hline
\end{tabular}

(*) Secção Francesa da Internacional Operária.

(**) Partido Trabalhista Independente, antes da formação do Partido Trabalhista (Labour Party).

(***) Partido Trabalhista.

Medido em termos eleitorais, o avanço dos partidos socialistas europeus foi fulminante. A socialdemocracia alemã teve 3.010 mil votos nas eleições para Reichtag em 1903, conquistando 81 cadeiras; 3.159 mil votos e 43 cadeiras em 1907; 4.250 mil votos e 110 cadeiras em 1912. Na Checoslováquia, em 1911, o partido socialista atingia 130 mil membros; o partido dinamarquês, às vésperas da guerra, ultrapassava 50 mil membros;

${ }^{11}$ Cálculos realizados por Patrick de LAUBIER, "Esquisse d'une théorie du syndicalisme", Sociologie du Travail, Paris, outubro de 1968. entre 1904 e 1910 havia duplicado o contingente de eleitores; o partido norueguês progrediu de 16 mil membros em 1905 para 36 mil em 1912, de 4 representantes no Parlamento (1903) para 20 em 1912. O partido sueco, de 8 mil membros em 1899, chegou a 64 mil em 1911. Em 1911 obteve 64 cadeiras no Parlamento contra 17 em $1905^{12}$

A expansão dos votos socialistas foi acompanhada do crescimento também rápido do movimento sindical. Em quase todos os países, no período de um decênio, os sindicatos dobraram o número de membros.

Número de operários sindicalizados ${ }^{13}$ (em milhares)

\begin{tabular}{|c|c|c|}
\hline País & 1904 & 1913 \\
\hline Grã-Bretanha e Irlanda & 1.866 & 4.000 \\
\hline Alemanha & 1.052 & 2.548 \\
\hline França & $836(1906)$ & $1.026(1914)$ \\
\hline Áustria & 189 & 600 \\
\hline Itália & $197(1907)$ & 327 \\
\hline Bélgica & $34(1905)$ & 131 \\
\hline Dinamarca & 65 & 128 \\
\hline Noruega & $8(1903)$ & 63 \\
\hline
\end{tabular}

A expansão do movimento sindical ganhou impulso nos anos imediatamente posteriores à I Guerra. Na Alemanha, os efetivos operários filiados aos sindicatos socialistas passaram de 2,5 milhões em 1913 para 8 milhões em $1920^{14}$. Na Inglaterra, o Trade Union Congress passou de 2.800 mil- membros em 1914 para 6.418 mil em 1920, chegando o total de sindicalizados a 8.300 mil nesta mesma data ${ }^{15}$.

Não interessa, pelo momento, analisar as organizações sindicais como tais mas destacar um aspecto típico do movimento operário europeu: a vinculação ideológica, amiúde orgânica, com os partidos políticos de tipo socialista. Em nenhum outro continente as associações sindicais permaneceram ligadas, formal ou informalmente, com um partido político,

${ }^{12}$ Cifras extraídas de Paul LOUIS, Histoire du Socialisme en France (1789- -1945), Paris, Marcel Rivière, 1946, e ed..

${ }^{13}$ Dados extraídos de Paul LOUIS, op. cit.

${ }^{14}$ Dados extraídos de Wolfgang HIRSH-WEBER, Los Sindicatos en la Política, Madri, Ed. Tecnos, 1964.

${ }^{15}$ Dados extraídos de G.D.H. COLE, A Short History of the British Working Class Movement. 
geralmente socialista. Em alguns países europeus (França e Itália, por exemplo), as divisões existentes no interior do sindicalismo correspondem a divisões ideológicas partidárias. $\mathrm{O}$ fenômeno não se confunde com outras situações observadas em países do Terceiro Mundo em que vigora o sindicalismo único e nos quais determinadas correntes políticas obtém o controle da organização sindical, às vezes imposta e garantida de cima pelo Estado. No caso europeu, o relacionamento com uma dada corrente política (partidos socialistas ou comunistas, na maioria dos casos, embora não se possa excluir os sindicatos de tendência católica) é espontânea e se relaciona à própria história da formação do movimento operário. Os sindicatos eram, formal e explicitamente, socialdemocratas ou comunistas (ou católicos, em proporção minoritária).

Em muitos casos, os sindicatos foram uma criação do movimento político socialdemocrata. Em outros casos, o partido é que se originou do movimento sindical. Em toda parte, o relacionamento partido-sindicato persiste até hoje, embora a tendência pareça ir na direção de uma ruptura dos laços orgânicos que vinculavam o partido político à organização profissional.

$\mathrm{Na}$ Alemanha, os sindicatos criados pela socialdemocracia a ela permaneceram subordinados até o Congresso de Colônia (1904) quando, a propósito da discussão sobre a "greve geral", proclamaram sua autonomia política. No Congresso de Mannheim (1906), o Partido aceitou a independência do sindicato mas os laços ideológicos não foram cortados. Embora afirmando a existência de problemas e interesses sindicais específicos, os sindicatos alemães continuaram até hoje majoritariamente socialdemocratas ${ }^{16}$.

Nos Países Escandinavos (Suécia, Dinamarca e Noruega) a formação dos primeiros sindicatos e seu posterior desenvolvimento efetuou-se sob a influência política da socialdemocracia. Nos três países, os laços entre o partido (socialdemocrata) e o sindicalismo unitário continuam bastante estreitos, embora sindicatos e partidos não se confundam enquanto organizações.

\footnotetext{
${ }^{16}$ Estamos considerando apenas os "sindicatos livres" alemães, isto é, social- -democratas. Mas estes foram sempre amplamente majoritários. Assim, em 1905, o número de membros dos sindicatos livres era de 1.344 mil contra 191 mil nos "sindicatos cristãos" e 117 mil nas Associações Sindicais Alemãs (Sindicatos Hirsch-Duncker); em 1931, as cifras eram, respectivamente: 4.134 mil; 698 mil e 149 mil. Dados extraídos de Wolfgang HirschWEBER, op. cit.
}

Na Bélgica, a Federação Geral dos Trabalhadores Belgas (FGTB), majoritária, está associada ao Partido Socialista. (A vinculação formal com o Partido só foi cortada depois da II Guerra). Na Holanda, a central sindical NVV, também majoritária face aos sindicatos cristãos, é socialista. Na Áustria, igualmente, os sindicatos, desde sua origem, mantêm estreito relacionamento, ideológico e organizatório, com a socialdemocracia ${ }^{17}$.

$\mathrm{O}$ caso francês apresenta algumas variações em comparação com o ocorrido na Alemanha, Bélgica, Países Escandinavos, etc. em virtude da persistência, por mais tempo, das doutrinas marco-sindicalistas no interior do sindicalismo e do repúdio às formas de atuação parlamentar e de relacionamento com um movimento socialista fracionado em numerosos grupos rivais ${ }^{18}$.

Em 1895, no Congresso de Limoges, diferentes sindicatos e federações operárias francesas, juntamente com algumas Bolsas do Trabalho ${ }^{19}$, decidiram a criação da Confederação Geral do Trabalho. Tal como a Federação das Bolsas, a CGT proclamou-se independente de todo partido político. Recusando-se a participar da vida política parlamentar, adotou uma linha de tipo marco-sindicalista, concebendo a ação sindical

${ }^{17}$ Ver: Walter GALENSON (ed.), Comparative Labor Movements, Nova York, Prentice-Hall, 1952; Walter GALENSON, Trade Union Democracy in Western Europe, Los Angeles, University of California Press, 1961. Para uma descrição mais detalhada da influência do pensamento socialista no movimento sindical em fins do século passado e começos do século XX, veja-se G.D.H. COLE, Historia del Pensamimento Socialista, México, Fondo de Cultura Economica, 1965, (2.9 ed.), especialmente os volumes III e IV: "La Segunda Internacional".

${ }^{18}$ Por volta de 1880 , quando o movimento operário, depois da derrota da Comuna, começou a se recompor, registravam-se os seguintes grupos socialistas: Parti Ouvrier, blanquistas, Fedération des Travaillerus Socialistes, Alliance Comuniste Révolutionnaire, Socialistas Independentes, etc..

${ }^{19}$ Ao lado das organizações sindicais propriamente ditas, desenvolveu-se o movimento das "Bolsas de Trabalho". A primeira delas foi criada em Paris em 1887. Em 1908, contavam-se em toda a França 157 Bolsas espalhadas pelas principais cidades. As Bolsas do Trabalho preenchiam múltiplas funções. Serviam como escritórios de emprego, como centro de informações e formação profissional e educacional para os trabalhadores, ofereciam auxílio para as vítimas de acidentes de trabalho, para desempregados etc.. Eram, enfim, um centro de debates e vida sindical. Criadas, no início, por iniciativa governamental, as Bolsas tornaram-se logo independentes de todas as agremiações e tendências políticas, inclusive dos partidos socialistas. Para a análise do sindicalismo francês deste período ver: Robert GOETZ-GIREU, La Pensée Syndicale Française, Paris, Armand Colin, 1948. 
como o instrumento por excelência da transformação revolucionária e como núcleo de reestruturação da sociedade futura. Ao contrário das trade-unions britânicas, a CGT recusou-se a apoiar candidatos nas situações eleitorais e a dialogar com os poderes públicos; rejeitou todo compromisso com o poder econômico e político. Na verdade, a CGT não se propôs a democratizar o Estado ou a ampliar sua participação nas decisões, no âmbito da empresa e do Estado. A greve geral seria o coroamento de um processo de lutas e de progresso da consciência revolucionária que oporia, de forma pura, os trabalhadores aos proprietários. Através dela, como observa André Philip, o sindicalismo afirmava seu ideal herdado de Proudhon: "a oficina substituirá o Estado"20. A Carta de Arniens (1906) foi a síntese das concepções revolucionárias de um sindicalismo que se pretendia obstinadamente revolucionário, apolítico e independente dos partidos ${ }^{21}$.

Porém, as tendências sindicalistas revolucionárias não se mantiveram. Depois da I Guerra, a CGT passou a se orientar por concepções de tipo socialista, mais moderadas. A cisão de 1921 e a subsequente criação da CGTU, de orientação comunista, recriou a divisão ideológica no interior do sindicalismo francês, superada mais tarde com a reunificação de 1936. Após a II Guerra, no entanto, recompôs-se o quadro característico do movimento operário na França, com a divisão do sindicalismo em três centrais de orientação ideológica divergente.

O desenvolvimento do sindicalismo italiano foi, em muitos aspectos, semelhante ao da França. As primeiras associações operárias surgiram sob inspiração anarquista e socialista. Posteriormente, os comunistas tornaramse a corrente política majoritária. Atualmente três centrais sindicais organizam o proletariado italiano: a CGIL, comunista e majoritária; a CISL, "democrática" e a UIL, socialista 22 .

${ }^{20}$ André Philip, Trade Unionisme et Syndicalisme, p. 256.
${ }^{21}$ TOURAINE e MOTTEZ consideram que a "desconfiança dos sindicalistas para com a
política não é senão a expressão de seu interesse exagerado por ela: impugnam a sociedade
inteira", "Classe Operária e Sociedade Global", in: Leôncio Martins Rodrigues (org.),
Sindicalismo e Sociedade, p. 68 .
22 Na Itália (e na França), a vinculação entre partido e sindicato não é orgânica como nos
casos inglês e escandinavo, de sindicalismo unificado. Nem por isso, ela deixa de existir de
fato. Cf. Walter GALENSON, Trade Union Democracy in Western Europe, Walter
GALENSON (ed.), Comparative Labor Movements. Veja-se também a pesquisa comparativa
$\mathrm{Na}$ Inglaterra, ao contrário do que sucedeu em outros países, o Partido Trabalhista, formado no começo do século XX, foi uma criação do movimento sindical. As considerações ideológicas, em comparação com a Europa continental, desempenharam papel secundário: a adesão dos sindicatos à ideia da criação de um partido próprio deveu-se, em ampla medida, a razões "práticas", consideradas do ângulo da atuação sindical ${ }^{23}$.

O Partido Trabalhista nasceu, assim, como um grupo de pressão, reunindo sindicatos, associações operárias e partidos políticos, como a Sociedade Fabiana e o Partido Trabalhista Independente ${ }^{24}$. Mediante um sistema de adesão em que o ingresso individual ao partido não era inicialmente permitido, em que o número de votos nos congressos partidários se faz segundo o número de membros de cada associação filiada ao Labour Party, os grandes sindicatos - com milhares de aderentes mantêm o controle do partido e decidem de sua orientação política.

Em 1918, o Partido Trabalhista adotou um programa de tipo socialista, de inspiração fabiana, reclamando a "propriedade comum" dos

de Joseph RAFAELE, Labor Leadership in Italy and Denmark, Madinson, The University of Wisconsin Press, 1962; Joseph LAPALOMBARA, The Italian Labor Movement: Problema and Prospecta, Ithaca, Nova York, Cornell University Press, 1957.

${ }^{23}$ As lideranças dos grandes sindicatos aceitaram com relutância a ideia de um Labour Party. A razão principal que finalmente as levou a apoiar a formação do Partido Trabalhista (1901) foi pragmática e fundada em considerações de natureza sindical e não política. "O caso Taff Vale criou o Partido Trabalhista", escreve G.D.H. Cole, A Short History of the British Working Class Movement (177-1947), p. 291. Na realidade, já havia precedentes de medidas semelhantes mas o caso Taff Vale foi o fator decisivo. "O conjunto do movimento sindical ficara agora advertido sobre a tendência para a adoção de medidas legais contra os sindicatos. Até esta época, os sindicatos de operários qualificados tinham sido passivos e espectadores ante os ataques políticos e econômicos contra os novos sindicatos. Mas, agora, estava ficando claro, mesmo para os sindicatos mais conservadores, que o conjunto do movimento sindical estava envolvido, e que a posição geral de todas as suas organizações estava sendo ameaçada". John SAVILLE, "Trade Unions and Free Labour: The Background to the Taff Vale Decision", in: Asa BRIGGS e John SAVILLE (eds), Essays in Labour History, Londres, MacMillan, 1967 ( $2^{\mathrm{a}}$ edição), pp. 345-6. Até a formação do Partido Trabalhista e mesmo depois, muitos sindicatos apresentavam seus candidatos ao Parlamento através do Partido Liberal.

${ }^{24}$ Observa Pelling que, quando o Partido Trabalhista definiu-se pelo socialismo, o resultado foi "uma espécie de compromisso entre o socialismo marxista, de um lado, e fragmentos de reforma social do tipo Chamberlain - Lloyd George, de outro lado". H. PELLING, A Short History the Labour Party, Londres, MacMillan, 1968 (3 ed.), p. 45. 
meios de produção e a "democratização da economia". As características organizatórias originadas de sua formação perduram até hoje. Ao contrário do que ocorreu em outros países, em que a vinculação orgânica entre o sindicalismo e o partido foi abolida, o Partido Trabalhista continua estreitamente ligado ao Trade Union Congress.

Embora, no caso inglês, o partido tenha sido criação dos sindicatos, o processo de sua formação não alterou uma das características básicas do movimento operário europeu: a vinculação do movimento associativo profissional com partidos políticos de tendências socialistas.

Não interessa aqui o grau de radicalismo das ideologias e ações operárias nem tampouco as diferentes fórmulas doutrinárias propostas em cada país em diferentes momentos. $\mathrm{O}$ aspecto comum, e ao nosso ver mais importante, é o esforço das camadas operárias para se expressar como classe, de modo autônomo, política e sindicalmente. (As formas concretas de expressão, assim como o êxito alcançado, variaram em função de um conjunto de fatores que não interessa examinar no momento).

Em cada sociedade nacional, os trabalhadores, como classe, procuraram as vias mais favoráveis de expressão própria não só no plano profissional mas também, e principalmente, no político, mediante a ação dos partidos que, algumas vezes, estiveram subordinados aos sindicatos, deles dependendo financeiramente. Em outros casos, os sindicatos foram criados pelos partidos. Aqui, os aspectos ideológicos desempenharam função mais importante. Como regra geral, quanto mais fraco o movimento sindical, mais importante o papel das lideranças intelectuais e dos fatores ideológicos.

A consciência socialista relaciona-se a este esforço de afirmação da classe em todos os planos da sociedade e une os diferentes grupos de trabalhadores acima dos interesses profissionais particulares de cada ofício ou setor industrial.

É a representação "classista" da sociedade que explica a fusão profunda e duradoura entre o profissional e o político, entre o sindicato e o partido. Como enfatiza Sturmthal,

os sindicatos e as organizações políticas operárias estavam tão intimamente ligados que apareciam como uma unidade; em muitos países surgiram juntos; em toda parte lutaram como um só exército e pereceram juntos ... Estavam convencidos que representavam não somente reivindicações materiais, ou um programa partidário, tão nobre quanto lhes parecia, mas uma Weltanschauung, um credo, um modo de vida e um modo de olhar a vida, melhor do que o de qualquer outro grupo ${ }^{25}$.

Essa associação entre o movimento sindical e o movimento político deu à classe operária europeia uma posição no conjunto da sociedade e uma influência na vida política nacional que os trabalhadores de outros países não chegaram a alcançar. Na Inglaterra, grande parte da bancada parlamentar do Partido Trabalhista é formada por dirigentes sindicais. Em 1951, na Casa dos Comuns, o Partido Trabalhista possuía 295 parlamentares. Desses, 105 eram designados pelos diversos sindicatos que assumiam a responsabilidade financeira pela candidatura. Entre os demais deputados, grande parte era também composta de sindicalistas. Contudo, não representavam, no Parlamento, o sindicato a que pertenciam ${ }^{26}$. Em 1960, o sindicato dos mineiros possuía o maior grupo de sindicalistas eleitos para o Parlamento, com trinta representantes. A seguir, vinham os deputados cuja eleição fora financiada pelo "Transport and General Union", com 14 representantes, e alguns outros sindicatos com um número menor de parlamentares ${ }^{27}$.

Atualmente, a filiação ao Partido Trabalhista pode ser de associações ou de pessoas, individualmente. Em 1959, havia 87 sindicatos filiados ao Partido com um total de membros que se elevava a 5,5 milhões. O número de membros de sociedades trabalhistas, de cooperativas, etc., era de aproximadamente 25 mil, e o número de membros individuais era de 847 mil. Como organizações filiadas ao Partido Trabalhista, os sindicatos têm o direito de estar representados na conferência anual do Partido em proporção ao número de seus efetivos, o que dá aos sindicatos amplo controle sobre a organização partidária. Ademais, no âmbito da sociedade, representantes dos sindicatos participam de numerosas comissões governamentais de nível nacional e local, ocupam posições nos ministérios (quando o Partido

${ }^{25}$ A. STURMTHAL, The Tragedy of European Labour (1918-1939), Londres, Victor Gollancz, 1944, pp. 16-7.

${ }^{26}$ G.D.H. COLE, An Introduction to Trade Unionism, Londres, George Allen and Unwin, 1953, p. 182.

${ }^{27}$ La Situación Sindical en el Reino Unido, Relatório da Organização Internacional do Trabalho, Genebra, 1961, p. 120 
Trabalhista está no governo), em comissões de administração de fundos sociais, de empresas nacionalizadas de planejamento econômico, etc.

Os sindicatos ingleses podem utilizar seus recursos para atividades políticas, tais como financiamento de campanhas eleitorais, pagamento de deputados ou de qualquer outra pessoa que ocupe cargo público, a serviço do sindicato. Estes gastos devem ser provenientes de um fundo político especial, originado de cotizações voluntárias de seus membros ${ }^{28}$.

Na Alemanha Ocidental, a Allgemeiner Deustscher Gewerkschaftsbund - DGB, Federação Geral Alemã dos Sindicatos - depois da II Guerra, quando da unificação do movimento sindical, rompeu seus laços com o Partido Socialdemocrata. A maior parte de seus membros, contudo, permanece ligada ideologicamente à socialdemocracia. Dos 519 deputados eleitos em 1957 para o Bundestag, 206 eram sindicalistas. Desses, 154 pertenciam ao SPD, 48 à CDU (União Cristã-Democrata), um ao Partido Alemão e três ao Partido Libera $1^{29}$. O Partido Social- -Democrata continua, portanto, abrigando a maior parte dos sindicalistas. Por outro lado, os sindicatos estão representados em múltiplas instituições públicas, ocupando postos nos conselhos e comissões dos diferentes ministérios. No setor da indústria do aço e do ferro, e nas minas, os sindicatos obtiveram participação nos Conselhos de Administração das empresas em número igual ao dos representantes dos acionistas ${ }^{30}$.

$\mathrm{Na}$ Itália, embora o movimento sindical propriamente dito esteja menos consolidado e seu poder de intervenção institucionalizada no interior das empresas seja menor do que em outros países industrializados da Europa, os trabalhadores, através da vinculação com diferentes facções políticas, especialmente com o Partido Comunista Italiano -aproximadamente 8 milhões de eleitores - obtêm, pela via parlamentar, um poder de intervenção bastante grande na política nacional. As divisões do movimento sindical e do movimento político, aliadas aos problemas decorrentes de uma industrialização

\footnotetext{
${ }^{28}$ Um membro do sindicato pode recusar-se a contribuir para o fundo político (contract out). Por volta de 1960, num total de 7.688 mil membros dos sindicatos, apenas $12 \%$ se recusaram a contribuir. La Situatión Sindical en el Reino Unido, p. 121.

${ }^{29}$ Dados extraídos de W. HIRSCH-WEBER, op. cit., pp. 147-8.

${ }^{30}$ Sobre os problemas criados pela participação dos operários na gestão das empresas, ver: Ralf DAHRENDORF, "Politique syndicale et structure des entreprises en Allemagne", Sociologie du Travail, abril-junho de 1962.
}

rápida e desigual, e à resistência dos grupos empresariais, dificultam a institucionalização do sindicalismo e sua integração na sociedade italiana ${ }^{31}$.

$\mathrm{Na}$ França, diferentes observadores concordam em considerar que os sindicatos possuem uma influência mais limitada e menos institucionalizada na vida das empresas e na política nacional do que em outros países industrializados, como a Inglaterra, Alemanha Ocidental e Países Escandinavos. Os sindicatos estão agrupados em três centrais sindicais principais: a CGT, majoritária com aproximadamente 2,5 milhões de membros: a CFTD, de origem católica e a F O, socialista, com aproximadamente 700 mil membros cada uma $^{32}$.

É nos Países Escandinavos, contudo, que os sindicatos se encontram mais integrados à vida política e social dos respectivos países, mais solidamente implantados e com maior poder e influência. A Suécia, com aproximadamente sete milhões e meio de habitantes, possui 2,5 milhões de trabalhadores sindicalizados; a Federação Dinamarquesa do Trabalho possui 720 mil membros numa população de 4 milhões de habitantes; a Federação Norueguesa congrega 550 mil trabalhadores numa população de 3,5 milhões. Nos principais setores econômicos, a taxa de sindicalização atinge cem por cento. Nos três países, os sindicatos, embora organicamente separados dos partidos socialdemocratas majoritários, com eles mantêm estreitas relações. A filiação ao Partido, por parte dos sindicatos locais, é voluntária. Porém, na Noruega, mais de 50\% dos membros do Partido Trabalhista vêm de adesões coletivas ou seja, dos sindicatos e associações operárias. Tal como na Inglaterra, a cotização dos sindicalizados para o

\footnotetext{
${ }^{31}$ Para a análise da situação atual do movimento operário italiano e dos problemas decorrentes do progresso técnicos e da reorganização industrial, veja-se especialmente: Franco MOMIGLIANO, Sindicatos, Progreso Técnico, Planificación Econômica, Barcelona, MOMIGLIANO, Sindicatos, Progreso Técnico, Planificación Econômica, Barcelona, Sociologie du Travail, abril-junho de 1962 (tradução brasileira in: Leôncio Martins Rodrigues (org.) Sindicalismo e Sociedade; Lúcio MAGRI, "Le modele de développement capitaliste et le probleme de l'alternative prolétarienne", Les Temps Modernes, n 196-197, 1962 (Tradução brasileira in: Leôncio Martins Rodrigues (org.), Sindicalismo e Sociedade; Lelio BASSO, "Démocratie et Nouveau Capitalisme"; Vittorio FOA, "Les Lutes ouvrieres dans le développement "Les Structures Syndicales", in: G. ADAM, F. BON, J. CAPDEIELLE e R. MOURIAUX, L'Ouvrier Français en 1970, Paris, Armand Colin, 1970.

${ }^{32}$ Dados extraídos de Gérard ADAM, "Les Structures Syndicales", in : G. ADAM, F. BON, J. CAPDEIELLE e R. MOURIAUX, L'Ouvrier Français en 1970, Paris, Armand Colin, 1970
} 
Partido é voluntária ${ }^{33}$. Os sindicatos estão representados em quase todas as comissões e instituições governamentais e participam institucionalizadamente da vida política desses países ${ }^{34}$.

As experiências nacionais europeias, não seria preciso ressaltar, não obedeceram estritamente a um modelo. Nos países em que a grande indústria surgiu mais cedo, a organização da classe operária refletiu o avanço da industrialização. Um proletariado mais homogêneo levou mais rapidamente a formação de um sindicalismo unificado nacionalmente, internamente mais coeso, menos dividido por querelas ideológicas; no plano político, houve a formação de partidos únicos da classe. O exemplo típico é oferecido pela Inglaterra e Países Escandinavos. Do ponto de vista do papel e função desempenhados pelo sindicalismo, um dos resultados foi a ampliação do poder de intervenção e controle dos trabalhadores sobre o sistema econômico e político. Em outros termos, isso equivale a dizer que a classe operária como classe obteve uma influência relativamente maior na vida nacional desses países.

Em outros lugares, a diversidade e os desníveis do processo de industrialização, rivalidades regionais, disputas religiosas, etc., impediram a constituição de um sindicalismo unificado, assim como de um único grande partido operário. As rivalidades sindicais e partidárias redundaram no enfraquecimento das organizações trabalhistas. O sindicalismo, nesses países, possui uma influência relativamente menor na política nacional e o fator ideológico é elemento bastante relevante na orientação das ações operárias. Este é o caso da França e da Itália. Porém, tanto num caso como noutro - e poderíamos destacar outras situações - o que parece ser comum à Europa é a expressão classista do proletariado industrial, relacionada às ideologias socialistas e à formação de partidos de base social predominantemente operária.

\footnotetext{
${ }^{33}$ Hubert FERRATON, Syndicalisme Ouvrier et Social-Démocracie en Norvége, Paris, Armand Colin, 1960, p. 153.

${ }^{34}$ Sobre o papel e função dos sindicatos na sociedade sueca, veja-se: La Situación Sindical en Suecia, "Memoria apresentada por uma mision de la Oficina Internacional del Trabajo", Genebra, 1961; cf. também: Walter GALENSON, Trade Union Democracy in Western Europe; e Walter GALENSON, "Scandinavia”, in W. Galenson (ed.), Comparative Labor Movements.
}

Seria possível estabelecer diferenças importantes entre o sindicalismo dos países europeus tomando como critérios seu grau de influência, suas estruturas organizatórias, suas atitudes face ao Poder estatal e econômico, etc.. Crozier, por exemplo, distingue no continente europeu os movimentos operários da Inglaterra e Países Escandinavos e os dos países latinos (França, Itália, Espanha, etc.). No primeiro grande tipo (Inglaterra e Países Escandinavos), a ação integradora do sindicalismo far-se-ia não tanto através da fábrica (como no caso do sindicalismo americano) mas através da sociedade e do Estado, pela via dos partidos políticos, controlados pelos sindicatos. No segundo tipo, dos países latinos, a mediação política seria igualmente importante, porém num clima em que sindicalismo é aceito com dificuldade pelos grupos econômicos (ou não é aceito totalmente, como no caso da Espanha) ${ }^{35}$.

Touraine e Mottez definem o sindicalismo francês como sendo de escasso poder e de forte oposição social; o sindicalismo inglês, ou alemão do após-guerra, como de forte poder e escassa oposição social. (O sindicalismo americano seria de escasso poder e de pequena oposição social). Ao caso francês corresponderia o conflito sem participação; ao inglês, a participação deliberativa; ao alemão, a vontade de controle operário, e ao americano, a participação conflitiva ${ }^{36}$.

Galenson, por sua vez, distingue três situações sindicais: 1) a da Itália e França, em que o sindicalismo encontra-se dividido em centrais sindicais rivais, com menor influência na vida das empresas e do Estado; 2) a da Bélgica, Holanda e Áustria, em que a divisão entre um sindicalismo de ideologia socialista e outro católico não prejudica seriamente o movimento sindical; 3) a da Grã-Bretanha e Países Escandinavos, em que prevalece a unidade sindical e o sindicalismo dispõe de grande poder $^{37}$.

É possível, portanto, se pretende uma precisão maior de análise, distinguir, no quadro geral do sindicalismo europeu, uma diversidade de situações relativas à influência das organizações sindicais nas empresas e

35 M. CROZIER, "Sociologia do Sindicalismo" in: Leôncio Martins Rodrigues (org.) Sindicalismo e Sociedade. O autor, na verdade, distingue, além dos tipos citados, um tipo norte-americano, outro soviético e outro característico dos países subdesenvolvidos.

${ }^{36}$ Alain TOURAINE e Bernard MOTTEZ, op. cit., p. 91.

${ }^{37}$ Walter GALENSON, Trade Union Democracy in Western Europe. 
no sistema econômico nacional; ao grau de seu inter-relacionamento com o Estado e com os partidos políticos; à proporção de trabalhadores sindicalizados; às orientações valorativas; ao padrão de relações profissionais, etc.. Como assinalam Dolléans e Crozier, nada apresenta, ao mesmo tempo, tantos contrastes e tantas similitudes como a história do movimento operário ${ }^{38}$.

Para as finalidades do presente trabalho não interessam as diferenças entre os movimentos sindicais dos países europeus. Interessa, pelo contrário, pôr em relevo suas semelhanças, os traços que lhes são comuns e que os diferenciam do sindicalismo das demais regiões do mundo, ou seja: a adoção, pelo movimento operário, de ideologias socialistas, o caráter "classista", o relacionamento entre a organização sindical e a organização política, e a importância que a classe operária adquiriu no interior das sociedades nacionais europeias.

Os aspectos relacionados à formação do proletariado na Europa que foram enfatizados não se reproduziram em nenhuma outra parte do mundo com a mesma intensidade. Em nenhum outro continente os pequenos núcleos socialistas dos inícios da industrialização conseguiram transformar-se nos grandes partidos operários de massa. Por outro lado, não se observou, fora da Europa, a vinculação das grandes centrais sindicais com as diferentes correntes políticas, geralmente de tipo socialista. Em termos mais gerais: em nenhuma outra parte o proletariado enquanto classe, e o socialismo enquanto ideologia, marcaram tão profundamente as sociedades nacionais.

\section{Classe Operária, Sindicalismo e Subdesenvolvimento}

Nos países do Terceiro Mundo, o alcance das ideologias operárias foi muito reduzido. Em alguns países da América Latina em que a industrialização tomou impulso relativamente cedo - Argentina, Chile, Uruguai e região sul do Brasil - é possível constatar a reprodução, em escala reduzida, de um movimento operário em muitos aspectos semelhante ao europeu ${ }^{39}$. A continuação da industrialização, a urbanização, e a entrada

38 Edouard DOLLÉANS e Michel CROZIER, Mouvements Ouvriers et Socialistes (Chronologie et Bibliographie), Paris, Les Editions Ouvrières, 1950, p. VIII).

${ }^{39}$ Cf. Hernan Ramirez NECOCHEA, História del Movimento Obrero en Chile, Santiago, Austral; Rubens ISCARO, Origen y Desarrollo del Movimento Sindical Argentino, Buenos Aires, Ed. Anteo, 1958; Robert ALEXANDER, A Organização do Trabalho na América de massas de origem rural no mercado de trabalho, entre outros fatores, contribuíram para o desaparecimento do velho movimento sindical de origem anarquista e socialista. Quando da crise das estruturas tradicionais de dominação, da intervenção estatal na área trabalhista e do aumento da participação das massas populares no processo político, geralmente as correntes populistas e nacionalistas suplantaram o anarquismo e o socialismo das antigas elites operárias desses países. Nas demais regiões da América Latina, de industrialização mais recente (e em geral mais limitada) a influência das ideologias operárias foi ainda mais reduzida.

Em razão do caráter incipiente da industrialização e do tipo de tecnologia utilizada, os trabalhadores fabris constituem uma parcela bastante minoritária no conjunto da população ${ }^{40}$ Não oferecem, ao contrário do que aconteceu na Europa Ocidental, uma base social suficientemente ampla para a formação de partidos operários de massa. Um partido que se pretendesse operário no sentido de procurar recrutar seus aderentes, militantes e eleitores basicamente entre trabalhadores fabris estaria condenado a ser uma perpétua minoria ${ }^{41}$. A alternativa seria uma política de aliança com partidos de outras classes ou, se elas não estiverem politicamente organizadas, um esforço no sentido de atraí-las para o "partido operário". Quaisquer que sejam os argumentos que justifiquem essa orientação, ela significa concretamente que o "partido operário" é obrigado - como condição para qualquer êxito - a apresentar em seu programa um conjunto de reivindicações que possa atrair outros setores da população, o que na prática faz com que esses partidos - quando conseguem se expandir - se tornem mais "populares" do que "operários".

Latina, Rio, Civilização Brasileira, 1967 e Labor Relations in Argentina, Brasil and Chile, Nova York, McGraw-Hill Book, 1962.

${ }_{40}$ Landsberger enumera os seguintes fatores que habitualmente enfraquecem a classe
Nove operária dos países latino-americanos: a) debilidade do setor industrial do ponto de vista de sua capacidade de absorção de mão de obra; b) importância das pequenas oficinas em comparação com as grandes empresas que normalmente, nos países industrializados, constituem os baluartes dos grandes sindicatos; c) estagnação ou lento crescimento do emprego no setor industrial; d) desemprego constante. Cf. Henry LANDSBERGER, "La Elite Obrara de América Latina y la Revolución, in: S. M. Lipset e A. E. Solari (eds.), Elites y Desarrollo en América Latina, Buenos Aires, Paidos, 1967.

${ }^{41}$ Naturalmente, nada impede que certos agrupamentos se proclamem ideologicamente "operários" embora a composição social de seus membros seja predominantemente de classe média: estudantes e intelectuais geralmente. 
No entanto, do ponto de vista ideológico, são comuns, nos países do Terceiro Mundo, agrupamentos políticos de tipo "socialista" que às vezes chegam a ser importantes. Dois aspectos, principalmente, Os diferenciam do socialismo europeu: em primeiro lugar, sua base social é mais "policlassista", do que "uniclassista", isto é, não são essencialmente partidos da classe operária: agrupam geralmente intelectuais, liberais, estudantes, militares, etc.. Para se transformarem em partidos de massa ${ }^{42}$, necessitam recrutar, além dos operários industriais, outras camadas populares majoritárias no conjunto da população: trabalhadores agrícolas, assalariados dos setores de serviços, camadas inferiores das classes médias, etc.. Em segundo lugar, embora algumas vezes a fonte de inspiração seja o socialismo operário europeu - na proporção que esses agrupamentos deixam de ser meros núcleos de propaganda e doutrinação intelectual para participar efetivamente da política nacional - sua prática passa a se estruturar em torno da temática do nacionalismo, do desenvolvimento econômico, da democratização das estruturas de poder, etc.. Em certa medida, são agências de modernização social e de desenvolvimento econômico. A propriedade privada, a luta de classes, como temas mobilizadores e motivadores dos trabalhadores industriais, desempenham papel menos importante do que a temática do desenvolvimento econômico e do nacionalismo. A estatização dos meios de produção e o planejamento econômico vinculam-se mais às aspirações de progresso e afirmação da soberania nacional do que à hostilidade à propriedade privada, ao lucro e à burguesia. Mais do que um "fim", o socialismo aparece como um "meio" para a realização de objetivos "desenvolvimentistas" que permitiriam às populações das nações jovens alcançar certos padrões de consumo vigorantes nas nações industrializadas. Nos países subdesenvolvidos, o socialismo é mais um "socialismo-nacionalista-desenvolvimentista", patrocinado por elites, de classes médias do que um "socialismointernacionalista-operário", patrocinado por elites de trabalhadores fabris. $\mathrm{O}$ primeiro enfatiza o desenvolvimento econômico, a soberania nacional, o anti-

\footnotetext{
${ }^{42}$ Não seria possível examinar toda a variedade de situações. Assinalemos apenas que, em Não seria possível examinar toda a variedade de situações. Assinalemos apenas que, em
muitos casos, tais partidos não chegam a ter uma participação legitimada na vida política, permanecendo como minorias militantes clandestinas.
} 30 imperialismo, a estatização ${ }^{43}$; o segundo enfatizava a luta de classes, a abolição da propriedade privada, a gestão operária, o igualitarismo.

As transformações do conteúdo das ideologias socialistas no Terceiro Mundo não derivam unicamente da fraqueza numérica do proletariado industrial. Outros fatores relacionados à situação de subdesenvolvimento, criando outro contexto social, afetam as orientações valorativas da classe. Frequentemente, observam Balandier e Mercier, o movimento operário dos países subdesenvolvidos deve participar de dois papéis:

um de defesa dos assalariados e, outro, de participação no esforço nacional, de conquista da independência política e econômica. A ação propriamente política - que invoca diretamente os interesses de uma ou de várias classes e leva, amiúde, a reduzir ao mínimo as oposições de grupos ou de classes para constituir uma frente nacional - reveste-se aqui de uma importância que não tinha nas origens do movimento operário europeu. $\mathrm{O}$ problema principal do sindicalismo é, então, organizar a luta social e a luta nacional. Segundo as circunstancias, um ou outro aspecto pode ser dominante ${ }^{44}$.

Sem esquecer o diferenciado mosaico de situações sociais, econômicas, políticas e culturais existente nos países das áreas periféricas, parece pouco provável que as características mais salientes que notabilizaram o movimento operário europeu possam se reproduzir nas áreas que iniciaram tardiamente o processo de industrialização. Mesmo não considerando a natureza da tecnologia contemporânea (e outros fatores que serão examinados no capítulo seguinte), é pouco provável que, nas "jovens nações", os trabalhadores fabris possam ter o mesmo peso social que a classe operária adquiriu nos países europeus e, principalmente, que as ideologias classistas "antiburguesas" tenham a mesma força de mobilização. Caberia aqui estabelecer uma distinção importante para a

\footnotetext{
${ }^{43}$ Para muitos países africanos, recém-saídos da dominação colonial, mal se poderia falar numa "burguesia", pelo menos no sentido ocidental do termo. A formação do Estado, iniciado sob a égide das antigas metrópoles, precedeu a consolidação das classes modernas. Quando da descolonização, as elites locais (a "burguesia burocrática") tomaram a iniciativa da introdução de "medidas socialistas" (estatizantes) com o fito de criar as bases de uma economia industrial.

${ }^{44}$ Georges BALANDIER e Paul MERCIER, "El Trabajo en las Regiones en Vias de Industrialización" in: G. Friedmann e P. Naville (eds.), Tratado de Sociologia del Trabajo, vol. II, p. 303
} 
compreensão das orientações dos trabalhadores e das massas populares das áreas subdesenvolvidas. Dada a ausência, nesses países, de uma poderosa classe empresarial nacional, os sentimentos antiburgueses, que na Europa foram capazes de motivar as ações operárias na luta contra o lucro e a propriedade privada, estão desempenhando papel menos importante nos países do Terceiro Mundo. Contudo, isso não implica necessariamente que as ideologias anticapitalistas não encontrem campo propício para sua expansão. Mais concretamente, nos países subdesenvolvidos, que são levados a se industrializar, o recurso aos investimentos estatais, a certas formas de planejamento e a outras medidas "socializantes" constituem a única alternativa de desenvolvimento ante a inexistência de uma classe burguesa capaz de liderar o processo de expansão econômica e a presença de outras "elites industrializantes". A emergência de orientações anticapitalistas, de parte de determinadas elites, e seu apoio, de parte das massas pobres e frustradas, pode significar, de fato, a rejeição geral do status quo social, econômico e político, aparecendo o socialismo como a única via para o desenvolvimento econômico. Uma vez que os trabalhadores fabris constituem parte minoritária da população, e não das mais miseráveis, podem ocorrer movimentos populares em que a participação operária seja comparativamente pouco importante em relação à das populações pobres do setor terciário, dos trabalhadores agrícolas e das "massas marginalizadas" das grandes cidades. Nessas condições, os conflitos com a empresa privada e a burguesia industrial não poderiam desempenhar papéis equivalentes aos da Europa. Especificamente, os problemas sócio-profissionais, originados da situação de trabalho fabril, não poderiam cumprir funções equivalentes do ponto de vista da mobilização da força de trabalho. A "consciência socialista", quando aparece, estrutura-se antes em relação à problemática do desenvolvimento e do nacionalismo do que em oposição à propriedade privada.

$\mathrm{Na}$ África, em especial nos países que recentemente saíram da dominação colonial, onde os sindicatos estiveram ligados aos movimentos de libertação nacional e colaboraram posteriormente na organização da sociedade nacional, o conteúdo nacionalista das orientações sindicais tende a predominar, atenuando o sentimento de oposição social, e subordinando as reivindicações dos trabalhadores aos problemas de luta contra o subdesenvolvimento e em favor da consolidação do novo Estado ${ }^{45}$.

Na América Latina, principalmente nos países de industrialização mais antiga como na Argentina, Chile e Uruguai ${ }^{46}$, em que os sindicatos encontram-se mais consolidados, os aspectos sociais e profissionais da ação sindical adquire maior relevo na mobilização dos trabalhadores e o sindicalismo assume mais claramente papéis de defesa de um grupo social específico, aproximando-se, destarte, do tipo de movimento sindical que vigorou ou que vigora na Europa.

De modo muito geral, os aspectos sociais preponderam sobre os aspectos nacionais quando o processo de industrialização está mais avançado e os problemas sócio-profissionais ligados à situação de trabalho adquirem relevância face àqueles relacionados à situação do operário enquanto consumidor pobre num país subdesenvolvido.

Seria temerário levar mais adiante essas generalizações. Não seria demais relembrar a diversidade de níveis de industrialização e modernização assim como de formação histórica e herança cultural do movimento operário nas áreas do Terceiro Mundo. Além da análise das características mais gerais das sociedades - níveis de industrialização, de urbanização, sistema político, etc., que situam o quadro social no qual o sindicato deve atuar - o modo particular de constituição do movimento sindical (por exemplo: em oposição aos centros de poder econômico e político, ou como criação do Poder central, etc.) podem afetar a orientação posterior do movimento sindical. Ademais, em muitos países subdesenvolvidos, embora a classe operária seja amplamente minoritária,

${ }^{45}$ Cf. Jean MAYNAUD e Anisse SALAH-BEY, El Sindicalismo Africano, Madrid, Ed. Tecnos, 1965; e' Ioan DAVIES, African Trade Unions, Londres, Penguin Books, 1966.

${ }^{46}$ Cf. Torcuato DI TELLA, El Sistema Político Argentino y la Clase Obrera, Buenos Aires, Eudeba, 1964; Samuel L. BAILY, Labor, Nationalism and Politics in Argentina, New Jersey, Rutgers University Press, 1967; Adolfo GURRIERI, "Consideraciones sobre los Sindicatos Chilenos", Aportes, Paris, julho de 1968; Victor ALBA, Politics and the Labor Movement in Latin America, California, Stanford University Press, 1968; Francisco ZAPATA Federaciones Centrales en el Sindicalismo Chileno, International Institute for Labour Studies, s.d.; Julio Cesar NEFFA, La participation de los Sindicatos en Argentina, International Institute for Labor Studies, s.d.; Manuel BARRERA, La Participación Social y los Sindicatos Industriales en Chile, Internacional Institute for Labor Studies, s.d. 
sua posição estratégica em indústrias importantes, sua proximidade com os centros de Poder e sua capacidade de organização superior a de outros setores populares ${ }^{47}$, podem outorgar aos sindicatos uma capacidade de interferência no sistema político bastante superior à que a simples expressão numérica da classe deixaria antever ${ }^{48}$.

Múltiplas situações nacionais que escapam do quadro que esboçamos podem ser encontradas. As considerações anteriores destinavam-se não a uma apreciação detalhada da classe operária e do sindicalismo nos países subdesenvolvidos, mas a destacar os elementos que os diferenciam do movimento operário europeu. Desse ângulo, quaisquer que sejam as diferenças nos níveis de organização da classe e as variantes ideológicas que distinguem os movimentos operários do Terceiro Mundo entre si, subsistem diferenças fundamentais com relação à Europa. Mais categoricamente, em nenhum país de industrialização recente a classe operária conseguiu formas de participação autônoma equivalentes às alcançadas pelo proletariado europeu; as ideologias operárias, apesar da influência do pensamento marxista, e algumas vezes da União Soviética enquanto nação, ficaram restritas a círculos intelectuais e a elites operárias minoritárias.

Em alguns países subdesenvolvidos, os sindicatos obtiveram alguma participação nas decisões do Poder em razão de sua associação com partidos nacionalistas ou movimentos populistas, o que, à primeira vista, reproduziria certas situações semelhantes às que se encontram nos países europeus onde os partidos socialdemocratas ou trabalhistas no governo apoiam-se nos grandes sindicatos (Inglaterra, Países Escandinavos, principalmente). Porém, na realidade, geralmente, em tais casos, os sindicatos estão inseridos num sistema autoritário de Poder, e mais do que aliados a partidos majoritários, são extensão do aparelho estatal dominado por elites nacionalistas desenvolvimentistas que, algumas vezes, se encarregam elas próprias da estruturação do movimento sindical, da

\footnotetext{
47 "No Sudão, uma greve geral precipitou a queda do regime de Abboud; na Nigéria, outra greve geral deu ocasião para uma prova de força entre o Estado e os operários; no Dahomey, no Congo (Brazzaville), na Alta Volta, na República Central da África, na Costa do Marfim, na Guiné e na Tanganica, os sindicatos têm sido identificados com atentados para a derrubada de governos; na Argélia, eles se transformaram no campo de batalha entre os regimes de Ben Bella e Boumediene". Ioan DAVIES, op. cit., p. 10.

${ }^{48}$ A Bolívia, com suas concentrações mineiras, constitui, nesse sentido, um caso típico.
}

mobilização e do enquadramento dos trabalhadores industriais em sindicatos paraestatais. Essa forma de participação, não seria preciso dizer, limita ou elimina a capacidade de mobilização autônoma dos sindicatos e reduz sua função de protesto e oposição ${ }^{49}$.

Somente nos países de tradição cultural europeia, que começaram a se modernizar mais cedo, como a Argentina, Uruguai e Chile, a classe operária ampliou sua influência autônoma na vida política nacional. $\mathrm{Na}$ Argentina, no entanto, apesar do peso social e político alcançado pelos trabalhadores industriais, não houve a formação de um partido socialista de massa equivalente aos existentes na Europa Ocidental. O peronismo, como movimento nacional-popular, terminou por suplantar as anteriores ideologias operárias ${ }^{50}$ No quadro latino-americano, o Chile constitui a exceção. Trata-se do único caso onde o conflito político e social assumiu caráter de classe, com a persistência de partidos operários de massa, de ideologia socialista.

A exceção constituída pelo Chile poderia ser explicada, em termos das hipóteses de Di Tella, pela conjugação de dois fatores: 1) a "situação de massas (operárias) isoladas" (concentrações mineiras) sem grandes

${ }^{49}$ A intervenção estatal nas relações industriais e o controle dos sindicatos e associações profissionais são mais intensos nos países subdesenvolvidos. A legitimação e organização dos sindicatos pelo Estado geralmente ocorre quando da ascensão de novas elites modernizantes ou nacionalistas ao Poder. Em alguns casos, malgrado as diferenças históricas e culturais nacionais, o autoritarismo das novas elites termina por outorgar aos sindicatos funções bastante semelhantes. Assim, por exemplo, comparadas as funções atribuídas por Vargas, em 1930, aos sindicatos brasileiros com aquelas determinadas pela revolução nasserista no Egito, as diferenças não parecem muito acentuadas: "As organizações operárias (egípcias) devem limitar-se a defender os direitos dos trabalhadores nas oficinas, solicitar aumentos de salários e melhorias nas condições de trabalho e, sobretudo, prestar serviços sociais. Não se espera que organizem greves e, principalmente, que se dediquem a atividades políticas". Frederick H. HARBINSON, "Egito", in W. Galenson (ed.), La Clase Obrera y el Desarrollo Económico, México, Editorial Limusa-Wiley, 1964, p. 222.

${ }^{50}$ Note-se que, na Argentina, a classe operária havia chegado a um nível relativamente elevado de organização sindical antes da ascensão de Perón ao Poder. A formação de um partido trabalhista de massa, pelos sindicatos, poderia ter ocorrido se não fosse a emergência do fenômeno peronista e a aliança entre um setor das classes superiores e o movimento sindical. Cf. Miguel MURMIS e Juan Carlos PORTANTIERO, Estudios sobre los Origenes del Peronismo, Buenos Aires, Siglo XXI Argentina Editores, 1971 (II Parte: "El Movimiento Obrero en los Orígenes del Peronismo"). 
concentrações urbano-industriais e 2) forte classe média ${ }^{51}$. A modernização precoce e o "desenvolvimento frustrado", juntamente com a importância das massas operárias mineiras, parecem ser variáveis importantes para explicar a existência de partidos socialistas e comunistas com forte base eleitoral. $\mathrm{O}$ peso dos contingentes mineiros (com a agressividade reivindicatória e o "obreirismo" que caracteriza esses grupos operários), ao que tudo indica, foi um fator importante na persistência de ideologias operárias. O deslocamento de massas de trabalhadores para o centro do país efetuou-se em conexão com a deterioração da indústria do salitre. As cidades absorveram, em proporção relevante, trabalhadores que já possuíam uma tradição sindical. No Brasil, por exemplo, o fenômeno migratório teve consequências contrárias: os antigos núcleos operários de origem europeia foram suplantados pelo afluxo de trabalhadores rurais, extremamente inexperientes do ponto de vista sindical e político ${ }^{52}$.

Em outros países latino-americanos, onde a industrialização alcançou níveis relativamente elevados mas ocorreu mais tardiamente e de modo bastante desigual, como no Brasil e no México, o movimento operário não só não alcançou os mesmos níveis de organização e de participação como não assumiu as mesmas características classistas.

\section{O Sindicalismo nos Estados Unidos}

Compreende-se a inexistência de partidos operários de massa e a fraqueza do movimento socialista e sindical nas regiões do Terceiro Mundo onde a industrialização não foi suficientemente ampla para propiciar a emergência de uma classe operária organizada em escala nacional. Porém, por que nos Estados Unidos - onde o processo de industrialização superou amplamente o da Europa Ocidental, possibilitando a formação de um movimento sindical agressivo e autônomo - as doutrinas socialistas tiveram tão reduzida influência? Por que não ocorreu a formação de partidos operários nem sequer semelhantes ao Labour Party inglês?

\footnotetext{
${ }^{51}$ Cf. T. DI TELla, L. BRAMS, J. - L. REYNAUD e A. TOURAINE, Sindicato y Comunidad, Buenos Aires, Editorial del Instituto, 1967 ("Introdução").

${ }^{52}$ Cf. Adolfo GURRIERI, Enzo FALETTO e Leôncio Martins RODRIGUES, "Estudo Comparativo do Comportamento Operário no Chile e no Brasil", Sociologia, São Paulo, junho-outubro de 1966.
}

A comparação entre a evolução do movimento operário europeu e do norte-americano é reveladora da complexidade de condições técnicas econômicas, sociais, políticas e culturais que precisam confluir para possibilitar a emergência de um movimento operário socialista orientado por concepções de luta de classes. Não basta a existência de uma classe operária organizada sindicalmente, agressiva e reivindicativa, para servir de base social para partidos operários. Parece discutível vincular mecanicamente a inexistência de uma consciência socialista entre os trabalhadores nos EUA ao êxito da economia capitalista e aos padrões de vida mais elevados ${ }^{53}$. Em poucos países do mundo os efeitos da crise de 1929 sobre a população assalariada foram tão profundos e prolongados. Nem por isso a radicalização do comportamento do proletariado americano ultrapassou os marcos do New Deal e do Partido Democrático.

Aparentemente, em termos dos chamados "fatores objetivos", aos quais se costuma associar a emergência do socialismo, todas as condições estavam dadas nos Estados Unidos: já em começos do século a nação americana estava constituída, com o desaparecimento das "fronteiras"; a grande indústria criara rapidamente um mercado nacional; grande parte do proletariado industrial estava concentrada em grandes empresas, oferecendo, portanto, as bases sociais para a formação de um partido operário, com possibilidades de obter uma representação própria no Congresso e nas assembleias dos Estados mais industrializados. A legislação eleitoral não excluía os trabalhadores do sufrágio eleitoral; os sindicatos estavam estruturados nacionalmente e possuíam recursos suficientes para financiar a formação de um partido político, tal como

\footnotetext{
${ }^{53}$ Nada indica que a expansão do sindicalismo e do socialismo esteja determinada diretamente pela miséria. Como mostra história do movimento operário, os grupos de trabalhadores que primeiro se organizam não são os mais explorados e miseráveis. A emergência e consolidação do sindicalismo requer grupos de trabalhadores relativamente estáveis no emprego industrial. Como procuramos mostrar, as primeiras associações de trabalhadores são formadas por elites operárias, por trabalhadores qualificados. Os momentos de crise e de recessão não são, é certo, os mais propícios para a expansão do sindicalismo. Podem, contudo, favorecer a difusão das ideias socialistas e orientar o movimento operário para ação política, para mudanças de estruturas. Para isso, cumpre que parcelas da classe já estejam relativamente organizadas em partidos e sindicatos que possam canalizar o descontentamento operário. Se tais organizações não existem, a miséria e o desemprego podem favorecer o aparecimento de lideranças caudilhescas ou carismáticas, provenientes muitas vezes das camadas médias ou superiores.
} 
ocorrera na Inglaterra, com o TUC e o Labour Party. Mais tarde, a crise de 1929 revelara a insuficiência dos mecanismos espontâneos do mercado como via para a recuperação econômica. A tradicional desconfiança dos sindicatos com relação à intervenção do Estado na área trabalhista diminuíra com a criação do National Labour Relation Board e as garantias legais que este proporcionara para a sindicalização dos trabalhadores das grandes empresas, facilitando a formação do CIO. A história do sindicalismo americano demonstrou que todas essas condições não foram suficientes para o aparecimento de um movimento socialista e para uma prática política autônoma dos trabalhadores, fora dos quadros do sistema partidário dominante.

No interior do movimento sindical, a influência socialista foi bastante fraca. No plano político, malgrado os múltiplos agrupamentos socialistas e algumas tentativas de atuação política, nenhum partido socialista obteve resultados expressivos, e nem os próprios sindicatos se interessaram pela criação de um movimento político próprio. Isto não significa que o sindicalismo americano - diferentemente da opinião bastante difundida - se mantivesse inteiramente indiferente ao processo político nacional, num estilo de business-unionism. Ao contrário: muitas vezes, o sindicalismo interferiu na política americana, em âmbito local e nacional, apoiando e financiando candidatos. Porém, a participação política dos sindicatos e dos trabalhadores industriais não se fez de forma independente, autônoma, classista. A intervenção dos sindicatos nas lutas políticas se realizou apoiando candidatos, designados pelas agremiações políticas majoritárias, que pareciam mais favoráveis às associações operárias segundo a fórmula de Gompers de "ajudar os amigos dos trabalhadores e castigar seus inimigos". Apesar da influência do sindicalismo inglês sobre a American Federation of Labor (federação de ofício fortemente descentralizada), esta última não tentou a criação de um Labour Party, como fizeram os sindicatos britânicos.

Apesar disso, a AFL, desde a época de Gompers, participara frequentemente do processo eleitoral, apoiando candidatos em eleições estaduais e nacionais ${ }^{54}$. O CIO, por sua vez, logo depois de sua formação,

\footnotetext{
${ }^{54}$ Por volta do começo do século, a AFL começou a abandonar sua tradicional hostilidade pelas atividades políticas. A mudança de orientação fora ocasionada pela necessidade de combater candidatos e leis contrárias aos sindicatos. Em 1906, o próprio Gompers participou
}

entrou ativamente na luta política ${ }^{55}$. A diferença com relação aos sindicatos europeus, portanto, não reside na simples participação ou rejeição da atuação política mas na forma e no conteúdo que ela assumiu num e noutro caso. Na Europa, a participação dos trabalhadores realizou-se a partir da imagem de uma sociedade dividida em classes antagônicas, entendida como o fato fundamental e total, que abarcava a totalidade da vida social e das ações dos homens, separando explorados e exploradores, oprimidos e opressores. A vinculação entre o político e o econômico efetuou-se a partir desta imagem da sociedade, da ideia de um antagonismo que fez da luta sindical e da atuação parlamentar elementos de um processo geral e comum de luta de classes. No caso norte-americano, a intervenção política dos trabalhadores, além de não ser sistemática e de destinar-se principalmente a impedir a adoção de leis antissindicais, não se fundava numa percepção classista da sociedade, numa filosofia que supõe um conflito irredutível de valores, a rejeição total da ordem social, a afirmação absoluta de um novo sistema econômico, de outro modo de organização das relações entre os homens, de outro estilo de vida.

Contudo, a história do movimento operário norte-americano, nos seus períodos iniciais, mostrou sucessivas tentativas de criação de partidos de trabalhadores, de movimentos reformistas e organizações baseadas em concepções de luta de classe e de remodelação social.

pessoalmente de campanha no Maine, tentando evitar a eleição para o Senado de Charles Littlefield, antissindicalista ferrenho. Em 1910, os sindicatos conseguiram eleger quinze sindicalistas para o Congresso, dos quais onze eram democratas, três republicanos e um socialista. Cumpre notar, no entanto, que a AFL obteve êxitos bem limitados nessa área. Cf. Philip TAFT, A Federação Americana do Trabalho, Rio, Distribuidora Record, 1965, especialmente pp. 301/3.

55 Por exemplo, nas eleições presidenciais de 1944, o CIO apoiou a indicação de Henry Wallace, e a AFL, a de Truman. Como Wallace não conseguisse sua indicação como candidato à vice-presidência, o CIO passou a apoiar Truman. Durante a campanha eleitoral, o CIO trabalhou também em favor da reeleição de Roosevelt para presidente. Uma vez que a Lei Smith-Connally impunha restrições à utilização dos fundos sindicais para campanhas políticas, o CIO contornou a lei mediante a criação de um Comitê de Ação Política, para o qual os trabalhadores contribuíam diretamente. 
Nas primeiras décadas do século passado houve o aparecimento de numerosos partidos de trabalhadores (os Workingmen's Parties) ${ }^{56} \mathrm{O}$ movimento "greenbackista" Labor Union $^{58}$. Mais tarde, a Ordem dos Cavaleiros do Trabalho propôs-se a organizar todo o povo em favor de uma reforma geral da sociedade, mediante o estabelecimento de um sistema de cooperativas de produção e distribuição. Estima-se que, em 1885, os Cavaleiros do Trabalho chegaram a ter 703 mil membros e a organizar 135 cooperativas de produção. A Ordem dos Cavaleiros do Trabalho não constituía propriamente uma associação sindical, mas uma organização ampla, agrupando trabalhadores, pequenos proprietários e assalariados. Porém, muitas das assembleias locais da Ordeni eram compostas majoritariamente de operários e atuavam como um sindicato. Daí os "conflitos juridicionais" com as uniões de ofício filiadas à AFL.

Posteriormente, em 1905, o Industrial Workers of the World (IWW), fundando sua ação em concepções de luta de classes, tentou integrar todos os trabalhadores, independentemente de sua qualificação, em sindicatos gerais, pondo fim às divisões de ofício e rivalidades sindicais que caracterizavam a AFL

No plano político propriamente dito, outros agrupamentos partidários, de ideologia socialista, existiram nos EUA. Contudo, em momento algum tiveram uma influência que se assemelhasse à alcançada na Europa. O Partido Socialista Norte-Americano (fundado em 1901) chegou a contar com cerca de 150 mil membros e a obter, nas eleições presidenciais de 1921, aproximadamente um milhão de votos ${ }^{59}$ No ano seguinte, começou o seu declínio. Na realidade, e de um modo geral, a influência das ideias

${ }^{56}$ Os Workingmen's Parties não tinham uma plataforma socialista. Preconizavam a jornada de trabalho de 10 horas, o sufrágio universal masculino, a abolição da prisão por dívida, a educação igual e universal e, principalmente, a interdição dos monopólios. Trata-se de um programa que reflete aspirações de pequenos proprietários e artesãos transformados ou ameaçados de serem transformados em assalariados.

57 Os "greenbackistas" propugnavam pelo rebaixamento da taxa de juros, de modo a "democratizar" o capital, colocando-o ao alcance dos pequenos empresários e das cooperativas de trabalhadores, reativando as atividades econômicas.

${ }^{58}$ A National Labor Union, criada em Baltimore (1866), foi, no dizer de Rayback, a primeira organização sindical estável a funcionar em escala nacional. Em 1870, a NLU transformouse no Labor Reform Party. Cf. Joseph RAYBACK, A History of American Labor.

${ }^{59}$ G.D.H. COLE, Historia del Pensamiento Socialista, Vol. IV, p. 232. socialistas foi bastante reduzida, não apenas eleitoralmente mas também no interior do movimento sindical. As associações operárias inspiradas em concepções de luta de classes e de reforma social não conseguiram senão êxitos passageiros face ao pragmatismo da AFL que se adaptou ao sistema de valores dominantes na sociedade americana. O IWW não chegou a criar um sindicalismo estável e não conseguiu subsisti, à feroz repressão que contra si foi desencadeada ${ }^{60}$. Antes dele, o reformismo dos Cavaleiros do Trabalho também malograra, ao oscilar entre um movimento popular e um sindicalismo operário. A expansão da grande indústria tornou as soluções que propunha cada vez mais inexequíveis e retrógradas. Enfrentando a concorrência dos sindicatos de ofício da AFL, os Cavaleiros do Trabalho, com seus rituais maçônicos, com seu evangelho social, com suas assembleias mistas de trabalhadores e pequenos proprietários urbanos e rurais, não encontrou uma filosofia e uma estrutura organizatória capaz de responder aos novos problemas surgidos com a organização em larga escala do trabalho industrial. O êxito obtido pela AFL na criação de um sindicalismo estável deveu-se, em larga medida, à rejeição do socialismo, à aceitação realista do capitalismo americano ${ }^{61}$.

É pouco provável, no entanto, que o pragmatismo da AFL possa ser explicado como resultado de uma "livre" opção das lideranças e que sua filosofia e estilo de atuação tenham sido, mesmo de um ponto de vista "utilitário", mais rendosos para a classe operária no seu conjunto. Perlman interpreta o sucesso da AFL como fruto do abandono definitivo de uma

\footnotetext{
${ }^{60}$ Por volta de 1924, "para todo propósito prático, o IWW estava morto, vítima da mais sistemática campanha de exterminação da história americana". J. RAYBACK, op. cit. p. 290. ${ }^{61}$ "Se a AFL triunfou com relação aos Cavaleiros do Trabalho é porque as condições econômicas e sociais dominantes condenavam estes últimos. Vimos que o movimento "greenbackista" perdera toda sua significação; assistimos à derrota das cooperativas. Em 1890, a "fronteira" praticamente desaparecera. A emigração para o Oeste não mais constituía um meio de escapar da fábrica. A aliança entre os operários e os fazendeiros, realizada por um momento no interior da Ordem dos Cavaleiros do Trabalho, revelou-se fraca c efêmera... A AFL olhou para frente. Ela não procurou a salvação da população operária numa retirada para formas ultrapassadas de organização econômica... Sua ideologia tem raízes mais profundas na vida da cidade, que se tornara incessantemente mais importante na vida social americana”. Robert MARJOLIN, L'Évolution du Syndicalisme aux États-Unis, p. 98/9.
} 
“ideologia do produtor" que até então caracterizara o movimento operário nos Estados Unidos, com os Cavaleiros do Trabalho, o "greenbackismo" e a NLA ${ }^{62}$.

É possível, como observa Perlman (e depois dele outros autores), que Strasser e Gompers tivessem percebido, antes de as demais lideranças, a inviabilidade de um tipo de orientação ideológica socialista, inspirada numa filosofia de luta de classes. Mas, em geral, não parece correto que o abandono das ideologias socialistas, a orientação exclusivista, corporativista e dirigida aos trabalhadores qualificados, necessariamente renda mais frutos ${ }^{63}$ para o movimento sindical, mesmo encarada a questão pragmaticamente.

$\mathrm{Na}$ Inglaterra, as ideologias socialistas desempenharam papel importante na organização dos trabalhadores não qualificados durante o movimento do "novo sindicalismo" anarcossindicalistas e anticapitalistas constituíram poderoso apelo emocional para a arregimentação dos trabalhadores e muitas vantagens sociais foram obtidas posteriormente mediante a ação política, em especial durante o período da Frente Popular.

O sindicalismo da AFL enfraqueceu a influência que os operários enquanto classe, poderiam ter na sociedade americana uma vez que só dispunham da organização sindical como instrumento de pressão sistemático.

Depois de 1919-20, nos EUA, quando mais de um milhão de trabalhadores entraram para os sindicatos, elevando o número total de membros para mais de 5 milhões, os efetivos sindicais norte-americanos estagnaram $^{65}$. Este total de trabalhadores sindicalizados nos EUA só voltou

62 (62) Selig PERLMAN, A Theory of the Labor Movement, Nova York, August M. Kelley, 1949 (1.9 ed.: 1928)

${ }^{63}$ Wright Mills considera que as elites sindicais norte-americanas, em comparação com as elites políticas, militares e econômicas dispõem de acesso apenas aos níveis médio de poder, de alcance local. W. MILLS, A Elite do Poder, Rio, Zahar, 1962.

${ }^{64}$ Ver a parte "The New Unionism and the First Counter-attack" in: H. A. CLEGG, Alan FOX e A. F. THOMPSON, op. cit.

${ }^{65} \mathrm{Na}$ realidade o declínio do sindicalismo na década dos anos 20 não ocorreu apenas nos Estados Unidos mas em quase todos os países industrializados. Na França, a cisão ocorrida na CGT - com a posterior formação da CGT Unitária, de orientação comunista - parece ter sido um dos fatores que resultou no enfraquecimento geral do sindicalismo. A CGT que chegara a 2,4 milhões de membros em 1920, pouco tempo depois havia retrocedido para 1,3 milhões. Em 1922, os efetivos das duas centrais sindicais reunidas giravam em torno de 550 a ser ultrapassado depois de 1937, com a formação do CIO e as facilidades que o National Labor Relation Board, da época do New Deal, ofereceu para a arregirnentação sindical ${ }^{66}$.

Não deixa de ser curioso observar como as teses de Perlman, naturalmente de um ângulo oposto e com finalidade diferente, convergem com as de Lênin no Que Fazer sobre a suposta incapacidade de a classe operária ultrapassar o "economicismo". Lênin enfatizava os aspectos econômicos da reivindicação sindical, o abandono da luta revolucionária quando os sindicatos "são deixados a si mesmos". Daí a importância do partido revolucionário. Perlman enfatizava a defesa das "leis do sindicato" e das "regras do trabalho" (work rules) e atribuía a orientação revolucionária dos sindicatos à influência dos intelectuais (o partido, na terminologia de Lênin). Não há dúvida de que a sistematização doutrinária origina-se normalmente dos grupos intelectuais. Desse ponto de vista, .a existência de intelectuais ou, num sentido mais lato, de uma inteligência marginalizada e crítica, parece desempenhar papel importante nas orientações do sindicalismo. O problema reside, entretanto, em• saber por que, em determinadas circunstâncias, a doutrina (seria melhor dizer "as doutrinas") dos "intelectuais" é aceita ou rejeitada pelos sindicatos e pelos trabalhadores, e por que esta e não aquela. As observações de Lênin e Perlman parecem mais aplicáveis ao sindicalismo de ofício da Inglaterra e dos Estados Unidos do que ao de outros países ${ }^{67} \bullet$

mil aderentes. Paul LOUIS, op. cit. p. 365. No mesmo sentido, cf. André PHILIP, op. cit., p. 304. Na Alemanha, os sindicatos socialdemocratas perderam aproximadamente 4 milhões de membros. Cf. W. HIRSH-WEBER, op. cit. Na Inglaterra, o número de operários filiados ao TUC baixou de 6,4 milhões em 1920 para 3,7 milhões em 1930, Cf. G.D.H. COLE, An Introduction to Trade Unionism.

${ }^{66}$ No caso americano um fator importante, mas não único, no declínio dos efetivos sindicais depois de 1920, foi a não incorporação dos trabalhadores das grandes indústrias. Cf. Florence PETERSON, Sindicatos Operários Norte-Americanos, Rio Agir, 1953, p. 77. No mesmo sentido, ver Lloyd REYNOLDS, Economia Laboral y Relaciones de Trabajo, México, Fondo de Cultura Económica, 1964, p. 51. Durante a depressão econômica, os trabalhadores europeus, ao contrário dos norte-americanos, em razão da existência dos partidos socialistas, puderam transferir de algum modo sua pressão para o plano político.

${ }^{67}$ Na França, o texto do Congresso da CGT em Amiens (1906) foi aprovado por 830 votos contra apenas 8. Ainda que Griffuelles não fosse, ele próprio, de origem operária, a resolução foi acolhida por delegados de trabalhadores. O IWW, nos Estados Unidos orientou-se por uma filosofia de luta de classes mesmo depois de cisão com os "intelectuais radicais" liderados por 
A predominância do "economicismo" que tanto Lênin como Perlman (entre outros observadores) notaram na evolução do sindicalismo, não se explica em razão da fraca influência do "partido" ou dos "intelectuais"68. Os agrupamentos políticos "radicais" sempre existiram. A questão é saber por que sua influência é, em determinadas ocasiões, maior ou menor. As influências "externas" nos movimentos sindicais tendem, geralmente, a ser tanto mais fortes quanto mais fracas são as associações sindicais. A importância dos "intelectuais" é mais acentuada nas fases de estruturação do movimento sindical, quando se trata de grupos de trabalhadores (às vezes de origem agrícola) de baixo nível de qualificação educacional e profissional, que começam a se mobilizar e adquirir experiência de vida urbana e fabril. Na medida em que o sindicalismo se consolida, normalmente há o declínio da influência das organizações políticopartidárias, dos líderes originários das camadas médias ou altas. Os sindicatos passam a ter interesses mais definidos. Forma-se uma liderança operária zelosa de suas posições e de seu controle sobre a classe. Por outro lado, os "intelectuais revolucionários" não se relacionam mais com uma massa de trabalhadores desorganizados mas com sindicatos estabelecidos, dotados de um aparelho administrativo complexo, com funções específicas e objetivos próprios, cujos dirigentes tendem a rejeitar a tutela e a interferência de grupos externos à classe operária, quaisquer que sejam eles.

As orientações valorativas mais gerais dos movimentos sindicais nos diferentes países parecem não depender da maior ou menor ascendência dos grupos intelectuais e nem tampouco decorrer de suas lideranças. Elas refletem, de algum modo, um "estado de espírito" existente entre a classe, uma dada percepção e julgamento da sociedade industrial que tornam os trabalhadores menos ou mais suscetíveis a um dado tipo de apelo ideológico

De Leon. É difícil entender como as ideologias de tipo socialista encontram acolhida entre os trabalhadores se não existem condições favoráveis para sua aceitação.

${ }^{68}$ Não é exato que o movimento sindical tenda a se concentrar nas reivindicações de caráter profissional ou na defesa das regras e do contrato do trabalho. A partir de um determinado momento de sua evolução, quando as organizações sindicais ampliam seu poder de intervenção e controle das decisões econômicas e políticas, não mais podem deixar de se ocupar com os problemas gerais do desenvolvimento econômico e do sistema de poder, embora esses aspectos passem a ser considerados de uma perspectiva diferente daquela que orientou o movimento operário nas suas fases de negação revolucionária (e frequentemente utópica) da ordem vigente. e doutrinário. O sentido das ações sindicais, por sua vez, é marcado não apenas pela percepção da sociedade de classes e de seu sistema de poder mas também pelas possibilidades concretas de que dispõem os trabalhadores e suas associações para atingir determinadas metas. Se aceitarmos que os grupos sociais - de modo variado e com menor ou maior grau de capacidade e de habilidade - tendem a defender seus interesses e definir certos objetivos, cumpre considerar conjuntamente os sistemas de valores que são capazes de afetar as aspirações e orientações dos trabalhadores, assim como os meios de ação disponíveis. As táticas do movimento operário não decorrem apenas de fatores ideológicos mas igualmente dos meios de pressão a que podem recorrer os diferentes grupos de trabalhadores (tipos de luta sindical, formas de pressão política, etc.).

No caso específico do movimento operário norte-americano, o êxito da AFL e o malogro das organizações rivais na constituição de um sindicalismo sólido deveu-se a certas transformações que ocorreram bastante cedo na sociedade americana e que restringiram as chances de um sindicalismo guiado por concepções de luta de classes, transformações que corroeram também as bases para uma orientação política socialista.

$\mathrm{Na}$ Europa Ocidental, pelo contrário, as tendências sociais e econômicas que deram origem ao movimento operário de tipo socialista perduraram por mais tempo. De modo geral, estas tendências derivaram de descompassos entre o progresso da industrialização - mais precisamente, de um dado tipo de industrialização - e o avanço do processo de modernização política ${ }^{69}$ e social. Esse descompasso criou, por um período bem mais longo do que na América do Norte, uma ampla classe operária marginalizada politicamente numa sociedade permeada por valores aristocráticos. Nos Estados Unidos, pelo contrário, a industrialização - que ocasionou a formação de um proletariado industrial numeroso, criando assim as bases sociais para a emergência de partidos classistas - foi seguida muito rapidamente de um processo de democratização e massificação que se transformou num obstáculo político para a consolidação de partidos socialistas e operários.

${ }^{69}$ Modernização política no sentido de Huntington, implicando racionalização da autoridade, diferenciação das estruturas e expansão da participação política. Cf. Samuel HUNTINGTON, El Orden Político en las Sociedades en Cambio, Buenos Aires, Paidos, 1972. 
Se se comparam os contextos europeu e americano de industrialização com o dos países do Terceiro Mundo, percebe-se que, embora muitos fatores alimentem o radicalismo operário e intelectual e criem aparentemente um contexto equivalente ao da Europa do século passado, favorecendo a existência de movimentos radicais de rejeição do status quo, as limitações do processo de industrialização restringem as bases sociais necessárias para a formação de movimentos operários de envergadura equivalente aos que a Europa conheceu.

O socialismo operário que, durante o século passado e começos do atual parecia um fenômeno geral a se reproduzir em toda parte onde ocorresse a industrialização capitalista, parece hoje um fruto exclusivo das características particulares das condições que cercaram a industrialização europeia. Isso não significa negar, no plano dos fatos, nem rejeitar, no plano normativo, a crescente influência dos valores igualitários e democráticos no interior das sociedades ocidentais desenvolvidas; não significa, tampouco, recusar, para os países do Terceiro Mundo, a alternativa socialista como uma via de desenvolvimento econômico e de justiça social. Significa, mais precisamente, considerar que as condições sociais para um socialismo baseado na classe operária e nas concepções marxistas de luta de classes tendem a desaparecer - ou já desapareceram na Europa Ocidental - e não se reproduzirão em outras partes do mundo.

\section{CApítulo II \\ O Desenvolvimento Europeu e o Proletariado}

\section{A Formação do Capitalismo na Europa}

Um primeiro ponto que deve ser salientado na análise da industrialização europeia é o fato de ter-se originado no interior de sociedades aristocráticas, de passado feudal. Conjugaram-se no desenvolvimento europeu sistemas axiológicos conflitantes: de um lado, as normas, valores e instituições da democracia política e, de outro, os da sociedade pré-industrial aristocrática. Apesar do triunfo da burguesia, o processo geral de democratização das instituições foi relativamente lento. A flexibilidade e o dinamismo que a industrialização e a urbanização impuseram nos hábitos e atitudes, na produção e no consumo, refletiram-se tardiamente no sistema político, embora a revolução industrial tivesse destruído as bases sobre as quais se assentavam a manutenção e continuidade da ordem tradicional, particularmente seu sistema de dominação. Valores de tipo aristocrático persistiram mesmo quando a base econômica principal da sociedade era dada pela indústria, sendo a burguesia a classe economicamente dominante ${ }^{1}$.

Face aos valores aristocráticos e burgueses, o proletariado afirmou ideais democráticos e uma ética do trabalho, opondo-se concomitantemente aos "ociosos" e aos "ricos".

$\mathrm{Na}$ Inglaterra, onde a expansão econômica liberal realizou-se com êxito nos quadros de uma sociedade ao mesmo tempo notavelmente burguesa e aristocrática, parte do radicalismo operário, durante largo período, alimentouse na repulsa não só à "exploração" mas também às "desigualdades legalizadas", como indica a popularidade das obras de Tom Paine. "Houve períodos, no apogeu do owenismo e do cartismo - escreve Thompson -, em que outras tradições tornaram-se dominantes (entre os trabalhadores britânicos). Mas depois de cada malogro, o substrato das suposições de Paine

1 Touraine utiliza o termo "sociedade proto-industrial" para designar as sociedades em que "a indústria ocupa já um lugar técnica e economicamente importante mas as relações sociais permanecem fundamentalmente dominadas por concepções pré-industriais”. A. TOURAINE, La Conscience Ouvrière, p. 311. 
permanecia intacto. A aristocracia era o alvo principal ... Por mais dura que fosse a luta sindical contra os empregadores, o capital industrial era considerado como fruto da empresa e fora do alcance da intromissão política. Até os anos da década de 1880, de um modo geral, foi dentro desse quadro que o radicalismo da classe operária permaneceu fixado"2.

A Revolução Francesa difundiu a crença de que a ascensão da burguesia implica necessariamente a abertura do sistema político. Contudo, a história da evolução do capitalismo mostrou que a expansão industrial pode realizar-se sob os mais diferentes arcabouços institucionais e que a democracia representativa não constitui absolutamente o quadro político que acompanha necessariamente a industrialização capitalista nas suas fases iniciais. Ainda nos casos em que essa se deu sob a democracia parlamentar, a participação política legitimada das camadas de baixa renda só ocorreu depois de passadas as décadas iniciais do processo de acumulação.

O prosseguimento da industrialização levou paulatinamente à mobilização de setores da população até então passivos, à diluição das formações estamentais e das instituições aristocráticas e à democratização do sistema político. Porém, na maior parte dos casos, as novas classes proprietárias - a burguesia industrial especialmente - não propugnaram pela abertura do sistema tradicional de poder mas buscaram apoiar-se nele, uma vez eliminados certos obstáculos para a sua ascensão e para a expansão das atividades comerciais e industriais. A propagação dos ideais igualitários e democráticos deveu-se principalmente aos novos grupos emergentes da classe média e do proletariado.

O importante, para a compreensão das atitudes e ideologias da classe operaria europeia, foi o descompasso entre, de um lado, o fechamento do sistema de Poder, a persistência de valores e instituições aristocráticos e, de outro lado, a mobilização da população, o desaparecimento da passividade tradicional das massas. A legitimação do sindicalismo e a extensão do direito de voto à classe operária, por exemplo, só ocorreram no dobrar do século $^{3}$. Os mecanismos de institucionalização dos conflitos e de

${ }^{2}$ E.P. THOMPSON. The Making of the English Working Class, Londres, Pelican Book, 1968 p. 783.

3 O sufrágio universal pode ser localizado, na Europa Ocidental, por volta do início do Século XX. Nos EUA, contudo, na década de 1830, o voto universal dos homens brancos era participação legitimada dos trabalhadores na política nacional apenas se tornaram relativamente difundidos quando a classe operária encontrava-se formada nacionalmente, o que implica a existência de um parque fabril adiantado, do prisma de sua capacidade de produção e produtividade.

$\mathrm{Na}$ verdade, vendo a questão do 'angulo tecnocrático, dificilmente qualquer "integração" da classe operária teria bases econômicas para se efetuar na fase de acumulação de capital. Paul Bairoch mostra como a expansão inicial das manufaturas e oficinas realizou-se mediante $o$ autofinanciamento e contínuas reinversões. O sistema capitalista, na sua fase de expansão, necessitava de altas taxas de lucros ${ }^{4}$, obtidos através de um equipamento rudimentar e da compressão máxima dos salários. Dispondo do mercado externo formado pelas colônias e semicolônias, e do mercado interno formado das camadas não operárias (durante certo período majoritárias no conjunto da população), a classe capitalista não teria possibilidades, nem motivos, para transformar seus assalariados em consumidores e redistribuir os ganhos de produtividade. A elevação precoce dos padrões de consumo dos trabalhadores industriais comprometeria a capacidade de reinversão do sistema. Em todos os países de velha industrialização, os partidos e sindicatos operários só foram legitimados depois de transcorridas muitas décadas do take-off. Houve uma correspondência entre a capacidade de pressão do proletariado e as possibilidades redistributivas do aparelho de produção capitalista. Em outras palavras: certa participação legitimada das associações operárias na vida social e política assim como a melhoria no padrão de consumo dos trabalhadores - por mais violentos que fossem os protestos operários - só ocorreram quando o sistema econômico já havia alcançado nível de produtividade relativamente elevado. Antes dessa fase, apesar do radicalismo das ideologias, a força sindical e política das camadas trabalhadoras era bastante pequena. A estruturação de uma classe operária

a norma. Cf. S. HUNTINGTHON. op. cit. Cap. 2: "Modernização Política: América e Europa". Cumpre ressaltar que, na Inglaterra, o sufrágio universal se estabeleceu aproximadamente duas décadas antes do que na Europa Continental.

${ }^{4} \mathrm{O}$ autor estima que a taxa de lucro na indústria têxtil estaria entre 20 a $30 \%$ do capital, tanto na França como na Inglaterra em começos do século. Para os Estados Unidos (1951-55), a taxa média de lucro, para o conjunto do parque fabril, seria de $12 \%$, antes do pagamento dos impostos. Paul BAIROCH, Revolución Industrial y Subdesarrollo, México, Siglo Ventiuno, 1967 (2 ed.), especialmente o cap. "A Acumulação de Capital". 
relativa- mente homogênea, concentrada nas grandes fábricas, organizada em sindicatos nacionais e dotada de maior poder de pressão, só ocorreu com o predomínio da grande indústria, isto é, quando a taxa de produtividade e a tecnologia mais avançada tornavam economicamente viável a elevação dos salários reais dos operários sem que a capacidade de reinversão do sistema industrial fosse seriamente prejudicada.

Houve, é certo, em alguns países, ocasiões nas quais os trabalhadores assalariados, e as camadas populares de um modo geral, lograram grande capacidade de pressão e participação, extemporânea talvez em comparação ao nível de desenvolvimento econômico. É o caso da França, explicável em parte pela elevada politização dos trabalhadores. Em 1848, e depois em 1871, as revoltas populares obtiveram êxito, mas de curta duração. Na reação que se seguiu, o sistema político voltou a fechar-se e a excluir o povo e os trabalhadores.

Formou-se, assim, nos países europeus de velha industrialização, um contexto social bastante peculiar que explica parcialmente a amplitude do radicalismo operário e a irradiação das doutrinas socialistas. Em fins do século passado, a expansão industrial estava suficientemente avançada, de modo a possibilitar a existência de amplas camadas operárias concentradas nas grandes cidades e nos ramos industriais mais dinâmicos; no plano sindical, os setores mais qualificados dos trabalhadores estavam organizados. No conjunto, a classe operária começava a sair do estado de miséria e de analfabetismo que dificultavam a participação sistemática nas atividades associativas. Por outro lado, diminuíra o imenso reservatório de mão de obra barata que constituíra o setor agrícola, ampliando a capacidade de barganha dos sindicatos. Em suma, as principais mudanças ocorridas na economia e na sociedade favoreciam, a largo prazo, os trabalhadores industriais, aumentando seu peso no interior dos países industrializados. Porém, numerosas barreiras restringiam o acesso legitimado das camadas assalariadas e de suas associações nas disputas eleitorais e na vida política. O contexto institucional, cultural e econômico da Europa Ocidental parecia corroborar amplamente as teorias proletárias, em especial as análises de Marx: formava-se, nas sociedades capitalistas europeias, uma classe operária cuja importância social e capacidade de luta aumentavam continuamente mas que continuava marginalizada no interior da sociedade ${ }^{5}$.

A situação de exclusão em que viveu a classe trabalhadora durante a industrialização do Século XIX, correlatamente a certas distinções de natureza estamental, herdadas da sociedade feudal, agiram no sentido de marcada diferenciação e separação entre as classes. Favoreceram, nesse sentido, a emergência do que se convencionou chamar de subcultura operária, à qual se associava um esforço educacional autônomo com conotações políticas e "classistas".

Assim, as fases iniciais do movimento operário foram assinaladas pela tentativa de formação de uma cultura de classe. É desse ponto de vista que se deve entender a importância que os militantes operários atribuíam à educação dos trabalhadores. Tentavam os dirigentes e ativistas sindicais, por meios autodidáticos, ampliar seus conhecimentos e transmiti-los aos demais. Procurando suprir as deficiências do sistema escolar da época, empenhavam-se em preparar-se teoricamente a fim de poderem oferecer uma contrapartida operária ao saber aristocrático, burguês ou religioso. A preocupação educacional tinha finalidades políticas, com a criação de centros de discussão que serviam de foco de aglutinação e politização dos trabalhadores. O autodidatismo não era apanágio dos líderes e teóricos, mas hábito bastante difundido entre as camadas mais qualificadas de trabalhadores, artesãos geralmente.

\footnotetext{
${ }^{5}$ A democratização dos sistemas políticos, nos começos do século XX, significou um ponto decisivo na evolução do movimento socialista europeu. O sufrágio universal, a legitimação dos sindicatos e dos partidos operários surge, à primeira vista, como um fruto da pressão da classe, como uma vitória dos trabalhadores. Em larga medida, assim foi efetivamente, uma vez que a democratização do sistema resultou de contínuos conflitos, do qual o movimento cartista é um exemplo. Porém, outros fatores começavam a operar nas sociedades europeias, em especial o progresso tecnológico e o aumento da produtividade que possibilitavam a melhoria dos padrões de consumo. A maior parte dos teóricos socialistas - fixados em esquemas rígidos de interpretação da sociedade capitalista - deu-se conta tardiamente das mudanças que começavam a ocorrer. A extensão do sufrágio e a legitimação das associações operárias alteraram o quadro político preexistente. As antigas coligações políticas dominantes tiveram que ter em conta a presença de forte representação parlamentar socialista. Do lado do movimento operário, a socialdemocracia comprometeu-se com as regras do jogo parlamentar. O reformismo e o revisionismo desenvolveram-se com a democratização do sufrágio.
} 


\section{Referindo-se à Inglaterra, escreve Thompson:}

Trabalhadores, artesãos, lojistas, amanuenses e mestres-escolas procuravam instruir-se a si mesmos, individualmente ou em grupo. Os livros e instrutores eram frequentemente aqueles sancionados pela opinião reformista. Um sapateiro que estivesse aprendendo a ler através do Velho Testamento iria continuar através do Age of Reason; um mestre-escola, cuja educação pouco ultrapassava as homilias religiosas, procuraria Voltaire, Gibbon e Ricardo ... Assim, os trabalhadores formavam um quadro da organização da sociedade ... que era, acima de tudo, um quadro político... Apesar da repressão que seguiu o ano de 1819, a tradição de criar tais "salas de leitura de jornais" (algumas vezes ligadas a uma livraria radical) continuou pelos anos da década de $1820 \ldots$ Nas pequenas cidades e aldeias, os grupos de leitura eram menos formais mas não menos importantes ${ }^{6}$.

S. Gomper, um dos fundadores da American Federation of Labor, e seu presidente por muitos anos seguidos, relata em suas memórias o hábito de leituras organizadas existente entre os trabalhadores charuteiros de Nova York por volta de 1870:

Havia também leituras que se faziam na fábrica enquanto se trabalhava. Era costume dos charuteiros organizar um fundo para a compra de jornais, revistas e livros e, enquanto os outros trabalhavam, um de nós era escolhido para ler, mais ou menos durante uma hora, ou talvez mais. Depois ... tínhamos uma espécie de debate que chamávamos, naquele tempo, de 'forum trabalhista' e essa prática muito contribuía para desenvolver, entre nós, uma certa acuidade em assuntos econômicos de importância ${ }^{7}$.

O autodidatismo e os clubes de debates, a preocupação cultural, não se restringiam apenas aos trabalhadores anglo-saxões. Referindo-se aos anarquistas andaluzes, escreve Hobsbawm: "Os obreiros conscientes eram ... mais educadores e propagandistas do que organizadores... Liam e se autoeducavam com entusiasmo apaixonante ... Seu maior prazer consistia em escrever cartas ou artigos para a imprensa anarquista, em geral cheios de frases

${ }^{6}$ E.P. THOMPSON, The Making of the English Working Class, pp. 789 e segs. no capítulo "Class Consciousness".

${ }^{7}$ Samuel GOMPERS, Sindicalismo e Trabalhismo nos Estados Unidos. Autobiografia, Rio, Ed. Presença, s/d., pp. 75-6. extensas e de uma torrente de palavras sublimes, glorificando as maravilhas do conhecimento científico que haviam adquirido e que estavam propagando"8.

Dois elementos eram importantes nas elaborações teóricas relacionadas a uma "cultura de classe": a valorização do trabalho "produtivo", isto é, do trabalho manual, do "produtor" que cria as riquezas do universo (expropriadas a seguir pelos burgueses) e a ideia de que, em oposição ao obscurantismo cultural e à irracionalidade da sociedade capitalista, seria possível a criação de um novo mundo, governado pelos próprios produtores e presidido pela razão ${ }^{9}$.

A produção teórica autônoma, assim como os esforços autodidáticos relacionados com o movimento operário, praticamente desaparecem depois da I Guerra Mundial. O Século XIX fora o século de ouro de elaboração de "sistemas" e de proposições alternativas de reconstrução Social de cunho socialista (no sentido amplo do termo). Do ponto de vista doutrinário, o Século XX acrescentou pouca coisa. À medida em que o sindicalismo se tornava menos ideologizado, as lideranças operárias despreocuparam-se com os problemas teóricos gerais e com a elaboração de doutrinas, passando a procurar soluções mais exequíveis para os problemas imediatos. Por outro lado, o avanço das ciências especializadas expulsou do campo os diletantes, operários ou burgueses.

Além das modificações relacionadas mais diretamente ao progresso científico e às condições de elaboração intelectual, outros fatores agiram para a destruição do "autodidatismo operário". Este se relacionava à

${ }^{8}$ E.J. HOBSBAWM, Rebeldes Primitivos, cap. V., "Os Anarquistas Andaluzes",

${ }^{9}$ A preocupação teórica foi comum aos principais dirigentes operários dos mais diferentes matizes ideológicos. Quase todos procuravam deixar publicada alguma obra expondo as suas concepções da sociedade presente e futura. Naturalmente, a Europa constituía o centro de elaboração teórica (e disputa doutrinária). Contudo, em alguns países latino-americanos em que o movimento operário e sindical desenvolveu-se cedo, o fenômeno tendeu a reproduzirse. Por exemplo, L.E. Recabarren, o dirigente operário chileno, escreveu uma obra denominada La Materia Eterna e Inteligente (1917), dedicada a "todos que tenham interesse em buscar as razões que mais nos aproximarão da verdade". Cf. Júlio César JABET, Recabarren, Los Orígenes del Movimiento Obrero y del Socialismo Chileno, Santiago, Prensa Latinoamericana, 1955. O mesmo tipo de preocupação intelectual e cultural existiu também no Brasil - em São Paulo mais precisamente - com os clubes de debates, animados por trabalhadores emigrados, anarquistas na maioria das vezes. Cf. Everardo DIAS, História das Lutas Sociais no Brasil, São Paulo, Editora Edaglit, 1962. 
situação peculiar dos trabalhadores no século passado, em especial com a situação de marginalidade, que possibilitava a formação de subculturas de classe e criava as condições sociais para as "teorias operárias".

Em toda parte, o processo de massificação - os meios de comunicação e consumo de massas, a extensão do sistema educacional, etc. - acarretou o declínio desta subcultura operária que correspondia, de modo mais amplo, aos "particularismos classistas" da sociedade europeia. $\mathrm{Na}$ Europa, o período que vai dos inícios da industrialização ao da massificação e ampliação do consumo foi bastante longo em comparação com os Estados Unidos e Canadá ${ }^{10}$. Criou-se nos países europeus um contexto social no qual as fronteiras entre as classes foram bem demarcadas. As diferenciações decorrentes do modo de inserção no sistema de produção correspondiam muito estreitamente a hábitos, padrões e possibilidades de consumo, modos de sentir, pensar e agir, atitudes e valores, tipo de vestimenta, de educação, de moradia, etc.. Essa correspondência profunda entre a situação do trabalhador enquanto produtor e enquanto consumidor, em que a subordinação na fábrica implicava a subordinação e a exclusão na sociedade, em que ser operário significava uma situação social total, embricou o conflito fabril aos conflitos políticos, favorecendo os modos de conduta classistas que deram base para a formação dos partidos operários e propagação das doutrinas socialistas ${ }^{11}$.

As formas concretas assumidas pelo radicalismo operário europeu não podem ser entendidas apenas com referência a uma situação de marginalização política e social dos trabalhadores no contexto de uma cultura aristocrática dominante. A oposição a uma ordem política excludente e a sistemas de valores aristocráticos tenderia a produzir, talvez, movimentos de tipo democrático, não fosse o quadro econômico de uma

${ }^{10}$ Em termos de Rostow, falar-se-ia no "arranco" e no "alto consumo de massas". Walt ROSTOW, Etapas do Desenvolvimento Econômico, Rio, Zahar, 1961.

${ }^{11}$ Almond refere-se, para a Europa continental, a uma "fragmentação da cultura política". G. ALMOND in: S. Sidney Ulmer (ed.). Introductory Readings in Political Behavior, Chicago, Rand McNally \&. Com., 1961 (Citado da tradução brasileira: "Sistemas Políticos Comparados", Sociologia Política II (vários autores), Rio, Zahar, 1970. O aspecto que nos parece fundamental, sem esquecer as influências de outros fatores - como o religioso, por exemplo - é que a fragmentação da cultura política se vincula, de modo menos ou mais direto, a uma subcultura de classe. industrialização dirigida por uma classe burguesa, visando o enriquecimento privado nas condições de um mercado competitivo e de reduzido intervencionismo estatal ${ }^{12}$

O socialismo europeu foi um socialismo antiburguês, operário, alimentado na oposição à propriedade capitalista. A consciência de classe, qualquer que seja sua conceituação, implica a referência, como "polo oposto", ao proprietário dos meios de produção. Ela supõe o modelo liberal de desenvolvimento, constituindo o lucro e a vontade de enriquecimento a mola principal do crescimento econômico, sendo a propriedade a base do prestígio, da riqueza e do poder.

A história das lutas sociais europeias mostra que a hostilidade ao capital e à propriedade privada foi mais intensa nas fases iniciais da industrialização, ou seja, justamente na fase da pequena empresa, do capitalismo familiar. Observa Mallet que o socialismo do sindicalismo de ofício, no plano ideológico, expressava as aspirações de reapropriação dos meios de produção de que fora despojado o artesão ${ }^{13}$. O socialismo marxista enfatizará posteriormente a propriedade coletiva dos meios de produção mediante a estatização da economia e o controle operário do Estado, continuando a tradição de oposição à propriedade, embora perceba a inviabilidade da reapropriação direta, pelos próprios produtores, dos instrumentos de produção, tal como preconiza o anarcossindicalismo.

Porém, na medida em que a grande empresa se impunha e as formas de administração familiar iam sendo substituídas por outras mais

${ }^{12}$ Claro está que o Estado, mesmo nos momentos de maior vigor do laissez-faire, jamais esteve inteiramente ausente da economia, principalmente quando se tratava de proteger a indústria nacional: “... cada país que se desenvolveu, no curso dos Séculos XVIII e XIX, optou pelo protecionismo nas primeiras fases de seu desenvolvimento. A Inglaterra não começou a proclamar e a querer impor seu livre-cambismo senão no ano de 1846, no momento em que seu avanço sobre os outros países era mais que evidente. A França só atenuou seu protecionismo em consequência da vontade expressada em 1860 por Napoleão III, protecionismo que, por outro lado, foi restabelecido com a tarifa de 1881. Os Estados Unidos inauguraram em 1865, tarifas altamente protecionistas, quando a proteção natural constituída pela distância que os separava dos outros países mais desenvolvidos diminuiu em consequência dos progressos nas comunicações e na redução dos custos de transportes daí resultantes". P. BAIROCH. op. cit., p. 139.

13 Serge MALLET, La Nouvelle Classe Ouvrière, Paris, Seuil, 1969, 2a ed. (Ver especialmente o cap. "Syndicalisme et société industrielle"). 
impessoais, ocupando os administradores profissionais o lugar dos antigos proprietários, as ideologias socialistas declinavam e a forma jurídica da propriedade foi deixando de ser um ponto importante na motivação da militância operária. De modo geral, nota-se a correspondência entre a hegemonia da grande empresa e o declínio das ideologias socialistas no interior do movimento sindical, como mostra o caso dos Estados Unidos, Inglaterra, Alemanha, etc..

A comparação entre as orientações operárias predominantes nos sucessivos estágios da evolução industrial (tipo de tecnologia, formas de administração, modos de organização do trabalho, etc.) sugere a correspondência entre, de um lado, o capitalismo competitivo, de empresas familiares e, de outro, a difusão de ideologias socialistas entre o proletariado.

Entretanto, parece discutível relacionar mecanicamente o aparecimento das doutrinas operárias com a pequena fábrica, considerando apenas os fatores forma da propriedade e de gestão. A passagem da empresa familiar para a grande sociedade anônima não se efetuou sem que outras mudanças ocorressem tanto no modo de organização e na técnica de produção como na sociedade industrial no seu conjunto (democratização do sistema político, difusão de valores igualitários, ampliação do consumo, etc.). As orientações valorativas da classe operária não podem ser atribuídas, ou relacionadas, a somente uma variável, embora o estudo do movimento operário europeu sugira que a propagação do socialismo tenda a encontrar terreno mais fértil na etapa da pequena empresa, de gestão familiar, com a correspondente tecnologia e tipo de qualificação da mão de obra.

A maximização do radicalismo operário e a emergência de condutas "classistas" parecem ocorrer quando a gestão familiar e a organização profissional do trabalho são coetâneas com estruturas de dominação política pré-industriais, de tipo aristocrático.

As formas clássicas do capitalismo liberal, de pequena empresa e tecnologia rudimentar persistiram mais tempo na Europa, particularmente na França, em razão, em parte, do ritmo relativamente mais lento da evolução tecnológica nas fases iniciais da industrialização.

A expansão inicial do sistema capitalista efetuou-se sem modificações técnicas de grande vulto. Não se trata de subestimar os efeitos de certas descobertas e de sua aplicação na indústria, tal como a spinning jenny de Hargreaves, do tear hidráulico de Arkwright, da mula de Crompton, enfim de todas as invenções que se associam à revolução industrial. Porém, mesmo no setor de fiação e tecelagem, as descobertas foram aplicadas lentamente e não foram responsáveis pelo aumento da produção que se verificou. Segundo Bairoch, antes da invenção de Arkwright, a produção de fios de algodão da Inglaterra, em trinta anos, havia aumentado em $117 \%{ }^{14}$. Embora na produção siderúrgica o progresso tivesse sido mais rápido, Dobb observa que:

os ofícios de acaba- mento de metal estavam muito atrasados. A indústria de pregos do Slack Country', nos anos seguintes a 1830, via-se em grande parte ainda em mãos de pequenos mestres e em pequenas oficinas e assim continuava, em grande parte, até os anos seguintes a 1830 ... Na fabricação de canhões, joalheria, fundição de bronze, selaria e arreamento, os anos seguintes a 1860 testemunharam ainda uma coexistência notável de processos de produção, altamente subdivididos, com a pequena unidade de produção e o dono da oficina distribuindo o trabalho aos artesãos que trabalhavam em suas casas. Em 1851, a malharia se baseava predominantemente nos sistemas de pequenos mestres-artesãos empregados pelos malheiros capitalistas num sistema de distribuição do trabalho em casa...

A revolução ocorrida fora de caráter social mais do que técnico. A persistência de um modo de realização do trabalho de tipo artesanal sob novas condições jurídicas permite explicar, em larga medida, as aspirações socialistas e a hostilidade à classe capitalista nascente. Para os trabalhadores, a classe proprietária, composta às vezes de mercadorescapitalistas, era uma classe de parasitas do trabalho alheio, que não exercia nenhuma função necessária no processo de fabricação.

Do ângulo da organização do trabalho, a produção manufatureira estava baseada na utilização de instrumentos rudimentares, polivalentes, operados por trabalhadores qualificados, possuidores de um ofício. Touraine denomina este período de sistema profissional do trabalho:

${ }^{14}$ P. BA1ROCH, op. cit. p. 19.

15 Maurice DOBB, A Evolução do Capitalismo, Rio, Zahar, 1963, cap. "A Revolução Industrial e o Século XIX”, passim. 
A empresa não tem uma verdadeira unidade; é apenas a coexistência de dois mundos: o da fabricação, no qual o operário qualificado possui ampla autonomia de decisão, e o mundo da administração, inteiramente reservado, na quase totalidade dos casos, à iniciativa patronal ${ }^{16}$.

O trabalhador possuía ampla margem de iniciativa na organização de seu trabalho, na realização das tarefas e escolha dos procedimentos a serem adotados. Nas palavras de Taylor, tratava-se de um sistema baseado no "estímulo" e na "iniciativa": estímulo pecuniário do proprietário e iniciativa do operário ${ }^{17}$

O papel da gerência, na organização da produção, era pequeno. Nas condições de uma divisão do trabalho ainda pouco desenvolvido, o operário - individualmente ou em pequenas equipes - era o verdadeiro fabricante. Na fase em que a produção, mesmo nas condições de uma comercialização capitalista, possuía fortes componentes artesanais, o trabalhador qualificado, auxiliado por aprendizes, era capaz de produzir sozinho uma dada mercadoria, segundo as especificações que lhe eram fornecidas pelo patrão. Porém, o resultado de seu trabalho já não lhe pertencia. Uma vez que o trabalhador habitualmente conhecia os preços do material utilizado e da mercadoria comercializada, a percepção do lucro açambarcado pelo capitalista era muito visível, e alimentava os ideais de uma economia dirigida pelos próprios produtores.

Durante longos anos, a produção capitalista continuou amplamente baseada em procedimentos técnicos bastante semelhantes aos que vigoravam na época artesanal. Porém, os trabalhadores "produtores" já se encontravam submetidos ao domínio do capital, já tinham perdido o fruto do seu trabalho e já estavam sujeitos às crises cíclicas de desemprego, à disciplina do proprietário, aos baixos salários, às más condições e às longas jornadas de trabalho.

O progresso na tecnologia industrial afetou a composição profissional da classe, as funções da gerência e da administração, a percepção que o operário tinha da empresa assim como suas atitudes face ao trabalho.

\footnotetext{
${ }^{16}$ Alain TOURAINE, "La Organización Profesional de la Empresa", in: G. Friedmann e P. Naville, (eds.) Tratado de Sociologia del Trabajo, vol. I, p. 384.

${ }^{17}$ Frederic W. TAYLOR, Princípios de Administração Científica, S. Paulo, Atlas, 1966, $\left(1^{\mathrm{a}}\right.$ ed. americana: 1911).
}

Especificamente, o parcelamento das tarefas e a desqualificação profissional agiram no sentido da destruição da "consciência de produtor". O operário, como observa Naville, "já não tem relações diretas com o produto e não reconhece claramente a utilidade social de seu ato" "18. Mallet, por sua vez, põe em relevo as relações existentes entre as formas de ação da classe operária e as mudanças na tecnologia e na composição sócioprofissional dos trabalhadores: "Entre os operários profissionais (qualificados), a 'consciência de classe' caracteriza-se, ao mesmo tempo, pela dupla consciência de ser explorado e produtor de riquezas". Entre os trabalhadores semiqualificados, especializados em tarefas simples, "a consciência de classe se baseia fundamentalmente no sentimento de exploração, e este é entendido como expressão de uma desigualdade na distribuição de riquezas" ${ }^{\prime 19}$.

A história do movimento operário oferece muitas evidências no sentido do relacionamento entre a tecnologia inicial do processo de industrialização, a composição profissional do proletariado, de um lado, a difusão de um tipo de ideologia coletiva e de formas de ação direta, de tipo anarcossindicalista, de outro lado. Foi nos países em que a pequena indústria, a propriedade e a gestão familiar perduraram por mais tempo (França, Itália, Espanha) que as ideologias de tipo anarcossindicalista tiveram mais difusão e persistência ${ }^{20}$. Na Inglaterra, Bélgica, Alemanha, por

${ }^{18}$ P. NAVILLE e P. ROLLE "La Evolución Técnica y sus Repercusiones en la Vida Social" in: G. Friedmann e P. Naville (eds.): Tratado de Sociologia del Trabajo, I vol., p. 353. No mesmo sentido observa E. Chinoy, em estudo sobre trabalhadores americanos de uma fábrica de automóveis: "Embora os operários da indústria automobilística, como muitos outros operários industriais, possam reconhecer o produto final para o qual contribuem, sua participação é tão pequena em consequência da divisão do trabalho, e tão insignificante em consequência da substituição da habilidade manual por máquinas, que os laços psicológicos entre o operário e o produto são tão tênues que podem ser considerados sem significado". Ely CHINOY, Auto. mobile Workers and the American Dream, Boston, Beacon Press, 1955, p. 85. Ver também, sobre os reflexos do trabalho parcelado sobre os operários, Robert GUEST e Charles WALKER, The Man on the Assembly Line, Massachussets, Harvard University Press, 1952.

${ }^{19}$ Serge MALLET, op. cit., p. 63 (sublinhado no original).

${ }^{20} \mathrm{O}$ anarquismo, nos países eslavos, não chegou a ter a mesma influencia sobre os trabalhadores e sobre os sindicatos que alcançou nos países latinos, principalmente Espanha e França. Foi mais um "anarquismo individualista" do que um "anarcossindicalismo". Bacunine e Kropotkine militaram a maior parte de sua vida fora da Rússia. Somente após a 
exemplo, onde a grande indústria se estabeleceu mais cedo, a influência do anarquismo foi menor e logo desapareceu, cedendo lugar aos partidos de tipo trabalhista ou socialista. A pequena indústria, na qual a organização do trabalho continua amplamente baseada nos trabalhadores qualificados, nos ex-artesãos transformados em assalariados, favorece tanto as doutrinas que defendem a gestão operária como as táticas que enfatizam as ações diretas e a importância das minorias militantes ${ }^{21}$.

$\mathrm{Na}$ medida em que as funções patronais concentram-se na comercialização do produto e no fornecimento do capital, a administração da oficina parece acessível aos trabalhadores, que podem prescindir do proprietário. Porém, quando a grande empresa, com sua complexidade organizatória e técnica se impõe, e a administração geral da produção requer habilidades e treinamentos especializados, tornando-se ao mesmo tempo atividades essenciais para o seu funcionamento e inacessíveis para os trabalhadores das linhas de montagem e das oficinas, as funções de gestão e administração tornam-se "produtivas". As soluções de tipo anarquista revelam-se cada vez menos exequíveis e menos capazes de motivar formas de militância operária.

O anarcossindicalismo por outro lado, só conseguiu certa expressão nos países de "tradição burocrática", de Estado centralizado e onipresente onde, como dizia Marx referindo-se à França, o "Estado enfeixa, controla, regula, superintende e mantém sob tutela a sociedade civil, desde suas mais amplas manifestações de vida até suas vibrações mais insignificantes, desde suas formas mais gerais de comportamento até a vida privada dos indivíduos" ${ }^{22}$. Pode-se entender certas formas de protesto anárquico dos trabalhadores como uma reação a Estados burocráticos e a situações de fechamento do sistema político que exclui as camadas pobres e veda suas associações. Em tal contexto, a violência súbita, a "ação direta", constituem

Revolução de 17 , o anarquismo conheceu um efêmero período de expansão, que terminou com a repressão de Cronstadt, em 1921. O movimento guerrilheiro de Makhnó, na Ucrânia, chegou a ser um movimento de massas, antes de ser liquidado pelos "comunistas autoritários". Entretanto, sua base foi essencialmente agrária, formada por camponeses pobres e não por operários. Cf. Daniel GUÉRIN, Anarquismo, Rio, Ed. Germinal, 1968.

${ }^{21}$ Cf. as observações de Touraine e Mottez sobre os relojoeiros do Jura in: "Classe Operária e Sociedade Global".

${ }^{22}$ K. MARX, O 18 Brumário de Luís Bonaparte, Rio, Vitória, 1956, p. 51. modos de expressão que substituem as negociações coletivas de um sindicalismo estável e legitimado. Mas as condições ideais para a expansão do anarquismo parecem se criar quando se conjugam, no plano político. Estados burocráticos e autoritários e, no plano econômico, a pequena oficina. Nos países em que a grande fábrica logo substituiu a oficina, o reformismo - de origem marxista ou não - triunfou sobre $o$ anarcossindicalismo.

É possível, ademais, considerar a influência da tecnologia sobre as orientações operárias não apenas do ponto de vista de seus efeitos sobre o tipo de tarefa, das relações entre o operário e a empresa, da composição profissional da força de trabalho, etc., mas também de um ponto de vista mais amplo, isto é, de seus efeitos sobre a importância social das camadas operárias no interior da sociedade.

Os estudos contemporâneos, principalmente aqueles voltados para os problemas da industrialização nas áreas subdesenvolvidas, vêm chamando a atenção para a dificuldade de abertura de novos empregos industriais e absorção de mão de obra nas condições da utilização de uma tecnologia que se convencionou chamar de capital-intensive. É claro que a questão passou despercebida aos analistas e participantes dos movimentos sociais do Século XIX e começos do século atual. A comparação do processo de industrialização europeu com o de países que iniciaram tardiamente o desenvolvimento econômico (e também a análise da industrialização contemporânea dos países desenvolvidos da própria Europa e América do Norte) permite captar melhor os efeitos da tecnologia não apenas sobre a criação de empregos mas sobre o papel e influência da classe operária nos países de "antiga" e "nova" industrialização ${ }^{23}$.

Apesar da elevação da produtividade, grande parte do aumento da produção registrado no início do crescimento europeu deveu-se ao acréscimo de novas unidades fabris e à consequente ampliação da força de trabalho empregada ${ }^{24}$.

${ }^{23}$ Uma análise das características da antiga e da nova industrialização encontra-se em
Gláucio D. SOARES, "A Nova Industrialização e o Sistema Político Brasileiro", Dados,
Rio, ${ }^{\circ} .2 / 3,1967$.
${ }^{24}$ S. Mallet chama a atenção para o crescimento numérico do proletariado na França: "Em
1856, a população empregada no setor secundário (indústria e transporte) era de 4.384 .000 61 
Este processo de industrialização labor-intensive que a Europa conheceu, resultou num constante aumento de força de trabalho fabril. Em fins do Século XIX, os reduzidos e esparsos grupos de operários se tinham transformado numa formidável massa de assalariados, englobando milhões de pessoas. Em poucos países do mundo, proporcionalmente, um volume tão grande de trabalhadores engrossou as fileiras da classe operária. Apesar da imprecisão do termo, pode-se dizer que a Europa foi mais "operária" do que os Estados Unidos, no sentido de que a proporção de trabalhadores fabris no conjunto da população foi maior. Nos EUA, o setor secundário, em termos de absorção de força de trabalho, nunca chegou a se constituir no setor mais importante, ao contrário do que aconteceu nos países mais industrializados da Europa.

População empregada no setor secundário e terciário em porcentagem do total da população ativa ${ }^{25}$

(O número entre parênteses representa o setor terciário)

\begin{tabular}{|l|l|l|l|l|l|l|}
\hline & 1880 & 1910 & 1920 & 1930 & 1940 & 1959 \\
\hline EUA & $24(26)$ & $31(37)$ & $33(47)$ & $31(47)$ & $34(48)$ & $34(57)$ \\
\hline Alemanha & $37(20)$ & $40(24)$ & $40(31)$ & $40(31)$ & $41(32)$ & $48(35)$ \\
\hline França & $27(25)$ & & $33(30)$ & $33(30)$ & $30(33)$ & $38(36)$ \\
\hline Grã-Bretanha & $50(37)$ & & $49(44)$ & $49(44)$ & & $50(46)$ \\
\hline Itália & $36(17)$ & $27(18)$ & $29(22)$ & $29(22)$ & $28(24)$ & $38(30)$ \\
\hline Bélgica & & $46(34)$ & $48(35)$ & $48(35)$ & & $47(43)$ \\
\hline
\end{tabular}

O quadro mostra, de um modo geral, o constante retrocesso da população do setor primário e o crescimento do terciário. Não caberia, entretanto, insistir no que é sabido depois dos trabalhos de Colin Clark. Interessa aqui observar que somente nos países de intensa $e$ antiga industrialização a diminuição da população empregada no setor primário se deu em benefício do secundário, fazendo com que a proporção de

pessoas. Porém, excetuando-se alguns grandes centros como Paris e Lion, ela se disseminava em inumeráveis pequenas cidades de província. Em 1881, data considerada como o começo do período de industrialização maciça, ela era ainda de 4.440.000. Em 1906, em consequência de uma progressão constante, ela atingia 6.338.000. Ter-se-á uma ideia da importância deste algarismo quando se sabe que, atualmente, a classe operária (mais os técnicos da indústria) agrupa 6.862 .000 pessoas ativas". S. MALLET, op. cit., p. 58.

25 Dados retirados de Jean FOURASTIÉ, "La Distribuición de la Mano de Obra", Tratado de Sociologia del Trabajo, vol. I, p. 219. As porcentagens para a Alemanha dos anos de 1940 e 1959 referem-se à República Federal Alemã. trabalhadores fabris no conjunto da população se tornasse elevada. Nos países latino-americanos, por exemplo, o setor secundário não tem revelado a mesma capacidade de absorção de mão de obra. Nota-se mesmo, em termos relativos, a diminuição da proporção de trabalhadores empregados no setor ${ }^{26}$.

Nos países europeus, a classe operária se transformou numa parte importante da população mas, se continuarem persistindo as atuais tendências tecnológicas, o fenômeno não mais se repetirá em qualquer outra parte do mundo. Nos países de antiga industrialização, a proporção de operários continuará a decrescer e, nos países subdesenvolvidos, o proletariado persistirá como uma parcela minoritária da população, ainda que o desenvolvimento assuma ritmo mais rápido e mais intenso, ocasionando um aumento do número absoluto de operários.

O tipo de tecnologia do século passado favoreceu indiretamente a expansão dos partidos socialistas ao ampliar a classe operária no decurso do desenvolvimento ${ }^{27}$. A política eleitoral da socialdemocracia, a partir da democratização do sufrágio, esteve calcada na ideia do contínuo crescimento da classe operária, na crença de que essa classe - bastante mais homogênea do que atualmente - iria se constituir, com a proletarização da pequena-burguesia e dos camponeses, na quase totalidade da população e, a socialdemocracia, no seu partido ${ }^{28}$.

Os progressos da tecnologia industrial, em especial a automação depois da II Guerra, reverteriam as tendências que vigoraram durante longos decênios de industrialização. Porém, antes que isso acontecesse, elas acarretaram a formação de uma classe operária mais numerosa, profissionalmente mais homogênea e culturalmente mais coesa do que em qualquer outro país.

26 Cf. Fernando Henrique CARDOSO e José Luiz REYNA, "Industrialização, Estrutura Ocupacional e Estratificação Social na América Latina” in: Fernando Henrique Cardoso, Mudanças Sociais na América Latina, São Paulo, Difusão Européia do Livro, 1969.

${ }^{27}$ Essas tendências, naturalmente, estão esquematizadas. Os partidos socialistas não recrutavam seus eleitores somente entre os trabalhadores e nem esses votavam unicamente nos partidos socialistas. Além disso, os operários, do ponto de vista ideológico e organizatório, nunca agiram sempre como um bloco, como atestam as organizações sindicais e políticas rivais.

28 Houve vozes discordantes da ortodoxia dominante. Berstein, ao desencadear a controvérsia "revolução vs. revisionismo", percebeu bastante cedo as novas tendências que despontavam na evolução do capitalismo. E. BERSTEIN, Socialismo Evolucionário, Rio, Zahar, 1964, (1 ed. 1899). 
Do prisma das análises das ações e ideologias operárias, cumpriria examinar também outras circunstâncias que cercaram o processo de formação da classe operária europeia, especialmente o modo como milhões de indivíduos sofreram o avanço do capitalismo. Em nenhum outro continente a industrialização foi vivenciada tão dolorosamente por tantas pessoas, em nenhuma outra parte do mundo o processo de formação da classe operária foi tão dramático. Conjugaram-se, de um lado, a natureza do sistema técnico da produção, o modo de organização do trabalho, e de outro, um processo de mudança descontrolado, que destruiu um modo de vida e de relações sociais secularmente estabelecido.

Não seria o caso de insistir nas más condições de moradia dos novos bairros operários, no ritmo estafante das longas jornadas de trabalho, na inexistência de leis sociais, nos baixos salários, nos períodos de desemprego. A monografia de Engels $^{29}$ constitui, ainda hoje, o quadro clássico da situação operária na emergência do capitalismo liberal, apesar de que a tese da deterioração do padrão de vida dos trabalhadores na fase de início da industrialização seja, às vezes, posta em discussão. Ashton, por exemplo, para o caso da Inglaterra, julga que, no conjunto, a situação melhorou nos primeiros anos do Século XIX:

Embora seja certo que, para 1831, o custo de vida tenha crescido em cerca de $11 \%$ em relação a 1790 , não é menos certo que os salários urbanos, na mesma época, aumentaram em mais de $43 \%$... O regime alimentar dos trabalhadores certamente melhorou: a farinha de trigo substituiu o centeio e a aveia, e a carne, que tinha sido escassa, se converteu juntamente com o centeio e a batata, no prato principal do $\operatorname{artesão~}^{30}$.

Hobsbawm, de modo contrário, trabalhando com dados referentes à mortalidade, saúde, desemprego e consumo, conclui que não há base sólida

29 A primeira edição é de 1845 . No prefácio escrito em 1892, o próprio Engels reconhecia que ocorrera uma melhora nas condições de vida dos trabalhadores ingleses: leis sociais, reconhecimento das trade-unions, extensão do sufrágio, etc.. Porém, atribuía a melhora ocorrida ao monopólio industrial britânico, condenado a desaparecer com o avanço da concorrência alemã e americana. Ver: La Situation des Classes Laborieuses en Anglaterre, Paris, Ed. Costes, 1933.

30 T. S. ASHTON. La Revolución Industrial (1760-1830), México, Fondo de Cultura Económica, 1964, pp. 163-4. para se aceitar a tese da elevação nos padrões de vida do conjunto das camadas trabalhadoras, enquanto há, pelo contrário, fortes evidências em favor das teses clássicas de um declínio. Mais precisamente, na opinião de Hobsbawm, durante a maior parte do Século XVIII o nível de vida da população teria aumentado e só teria começado a decair a partir de 1780. A tendência ao decréscimo só teria se alterado depois de $1840^{31}$.

Mais recentemente, Deane chega a conclusões semelhantes às de Hobsbawm. Segundo ele “... se levarmos em consideração as más safras, a população crescente, as privações de uma guerra e a depressão ocasionada pela deslocação econômica do após-guerra, podemos concluir de maneira razoável que, no cômputo geral, os padrões de vida médios tendiam a cair e não a subir" (entre 1780-1820). Para o período que vai de 1820-1840 as evidências, numa ou noutra direção - sempre de acordo com Deane - já não seriam tão sólidas. Somente a partir de 1840 é que as informações disponíveis indicam, de modo mais incontestável, uma elevação geral e relativamente substancial nos padrões de consumo ${ }^{32}$.

Como quer que seja, parece indiscutível que os aspectos negativos decorrentes da emergência do capitalismo industrial na Europa não encontram equivalência com nenhuma outra parte do mundo, seja de industrialização ligeiramente posterior, como a da América do Norte, seja de industrialização recente nas regiões do Terceiro Mundo.

Os traços comuns do desenvolvimento europeu derivam do fato de se tratar de um processo de industrialização conduzido por uma classe burguesa em regime de economia de mercado e de laissez-faire. O crescimento econômico foi procurado mediante um esforço de exploração máxima da força de trabalho, desorganizada sindicalmente e desprotegida socialmente durante longo tempo. Em segundo lugar, efetuou-se no interior de sociedades dominadas por valores aristocráticos e sob um sistema político que excluía os trabalhadores e as camadas pobres do "direito de cidadania" ${ }^{33}$. Em terceiro lugar, baseou-se numa tecnologia que permitiu a

${ }^{31}$ E. J. HOBSBAWM, Labouring Man, cap.: "The Bristish Standard of Living, 1790-1850". ${ }^{32}$ P. DEANE, A Revolução Industrial, Rio, Zahar, 1969, p. 283.

${ }^{33}$ No sentido de Marshall: “... se sustentarmos que no Século XIX, a cidadania na forma de direitos civis era universal, os direitos políticos não estavam incluídos nos direitos de 
formação de uma ampla e relativamente homogênea camada de trabalhadores fabris, favorecendo a emergência das doutrinas de reorganização social e de negação do sistema capitalista, criando as condições de possibilidades para o êxito relativo dos diferentes partidos de base social operária.

De modo esquemático, de acordo com a exposição precedente, os principais fatores que parecem determinantes das feições particulares assumidas pelo movimento operário europeu poderiam ser assim sintetizados:

1. O desenvolvimento industrial, em razão de sua extensão e tecnologia labor-intensive, criou uma classe operária numerosa e internamente homogênea do ponto de vista de sua composição profissional;

2. Socialmente, a força de trabalho foi buscada seja entre antigos setores artesanais, seja entre a pequena-burguesia urbana, seja - geralmente quando a grande indústria ganhou impulso - entre camponeses. Qualquer que seja, no entanto, a origem da mão de obra, a incorporação à vida fabril significou antes um rebaixamento do que uma ascensão na escala social e foi sentida negativamente pelos trabalhadores;

3. Politicamente, durante quase todo o transcorrer do século passado, o acesso ao sistema de decisões esteve fechado aos grupos de trabalhadores; a legitimação da participação política e sindical da classe ocorreu quando a industrialização encontrava-se relativamente avançada e os trabalhadores já constituíam amplos setores da população;

4. Correlatamente, o Estado esteve praticamente ausente do processo de industrialização e das questões sociais; na área trabalhista, sua intervenção foi geralmente de natureza antissindical;

5. O crescimento econômico decorreu do livre jogo do mercado e dos esforços de enriquecimento privado das novas camadas empresariais. $\mathrm{O}$ papel de outros grupos sociais não ligados diretamente à economia (tecnocratas, militares, intelectuais, etc.) foi relativamente sem expressão;

cidadania. Constituíam o privilégio de uma classe”. T. H. MARSHALL, Cidadania, Classe Social e Status, Rio, Zahar, 1967, p. 69-70.
6. Culturalmente, a persistência de instituições e normas de natureza aristocrática entrou em conflito com os valores democráticos e igualitários que tendiam a surgir com o prosseguimento da industrialização e urbanização, aprofundando os conflitos entre as classes;

7. Os recursos necessários para o desenvolvimento econômico originaram-se basicamente do próprio setor industrial, dada a pequena influência dos capitais estrangeiros e dos reinvestimentos agrícolas. As disputas entre as potências industriais europeias pelo controle dos mercados estrangeiros acentuou os esforços na direção da racionalização da produção industrial, da intensificação do ritmo de trabalho e da exploração máxima da força de trabalho.

8. Em todos os países, as associações operárias se afirmaram em oposição ao poder econômico e político, resultando sua legitimação da ação autônoma dos grupos de trabalhadores e não do patrocínio do Estado ou de outras "elites industrializantes".

A partir daí, e mais abstratamente, as seguintes variáveis parecem particularmente relevantes para a análise do movimento operário em outros contextos nacionais:

1. A importância assumida pela indústria no sistema econômico e a natureza dos procedimentos tecnológicos que determinam, mais diretamente, o volume da mão de obra empregada e, consequentemente, o peso social da classe no conjunto da população; a estrutura profissional do proletariado, o nível de qualificação, os salários, a concentração em grandes ou pequenas empresas, no meio rural ou em grandes cidades, etc.;

2. A origem social da força de trabalho (artesãos, trabalhadores agrícolas, pequena-burguesia urbana, etc.) e sua situação social e econômica na fase anterior à sua inserção no sistema capitalista;

3. O sistema político, menos ou mais sensível ou aberto às pressões ou participação dos trabalhadores; o nível e o tipo de participação das associações operárias nas decisões do Poder e o modo como a obtiveram;

4. O papel do Estado no processo de desenvolvimento, o tipo e o grau de sua intervenção na vida econômica e social, nos assuntos trabalhistas e conflitos industriais; 
5. A importância das diferentes elites ou grupos sociais na política econômica e na orientação do desenvolvimento; sua influência e participação nas decisões;

6. As ideologias e valores dominantes na sociedade e entre diferentes camadas sociais;

7. A origem dos capitais e recursos utilizados para o desenvolvimento (setor industrial interno, privado ou estatal, investimentos estrangeiros, capital comercial ou agrícola);

8. Modo de constituição das associações operárias, natureza dos obstáculos existentes para sua expansão e consolidação.

Seria ocioso insistir que os fatores acima foram detalhados para fins de análise e que, nas diferentes etapas, entrelaçaram-se produzindo situações concretas variadas. Isoladamente, os rumos do sindicalismo e do movimento operário, julgados em escala nacional, não podem ser imputados à ação de uma única variável. Ademais, os fatores discriminados não são exaustivos. $\mathrm{O}$ exame de situações particulares deve ter em conta outras variáveis ${ }^{34}$. Julgamos, porém, que as apontadas anteriormente, do prisma de sua contribuição para a análise histórica e global do sindicalismo e das condutas operárias em diferentes países, são as mais significativas.

\section{Sociedade de Massas e Sindicalismo}

Comparado o sindicalismo atual com o do passado, dois aspectos parecem sobressalentes na sua evolução: de um lado, o aumento do poderio das organizações operárias, medido pelo número de membros, recursos financeiros, controle sobre as condições de trabalho, participação nas decisões nacionais e, de outro lado, o declínio do radicalismo, das

${ }^{34}$ JOSEPH A. RAFFAELE (Labor Leadership in Italy and Denmark) apresenta outros fatores que considera importantes para a análise de diferentes "sistemas trabalhistas" (labor systems): 1) Diversidade de padrões sociais entre operários, líderes sindicais e empregadores; 2) Diferenças de orientações valorativas; 3) Diferenças de atitudes com relação aos sindicatos; 4) Diferenças nas atitudes com relação ao conflito; 5) Características das relações entre empregados e empregadores; 6) Diferenças nas motivações dos líderes sindicais ao aderirem ao movimento operário; 7) Diferenças na percepção que as lideranças operárias têm de seus papéis; 8) Diferenças na apresentação das organizações que competem pela liderança dos trabalhadores; 9) Diferenças de êxito; 10) Diferenças de características da força de trabalho. Para maiores especificações, ver o capítulo "Conclusions and Implications". concepções milenaristas de reconstrução social, da violência nos conflitos e das ideologias operárias. Não seria preciso dizer que essas mudanças, que a história mostrou não serem mutuamente excludentes, não resultaram de uma evolução linear do sindicalismo e dos partidos operários europeus. $\mathrm{O}$ processo foi bastante longo e complexo, repleto de avanços e recuos que possibilitam encontrar, no presente aqui e ali, exemplos da persistência do "velho radicalismo operário" que mantém acesa, em certos meios intelectuais, a crença na natureza revolucionária da classe.

Um rápido esboço da situação atual do sindicalismo nos países industrializados mostraria que nenhuma organização sindical importante tem, de fato, suas ações orientadas por concepções revolucionárias que, no passado, constituíram poderosos apelos para a militância operária. $\mathrm{O}$ declínio das ideologias revolucionárias foi paulatino e dependente de um conjunto de circunstâncias que variou de um país para outro. As associações operárias tentaram conciliar, por longo período, uma concepção revolucionária da classe, desarquivada nos momentos de conflito, com uma prática reformista, dirigida para a obtenção de vantagens imediatas e desvinculadas de uma concepção global de remodelação social e de luta de classes, cujo fim último seria a instauração de uma sociedade socialista e a abolição do patronato.

Esta evolução não se efetuou sem tensões e conflitos no interior do sindicalismo e dos partidos operários, tanto mais acirrados quanto mais vigorosas tinham sido as ideologias revolucionárias anteriores ${ }^{35}$.

O declínio das ideologias proletárias revolucionárias se deu, quer pelo desaparecimento das organizações orientadas por concepções de luta de classes na competição com outros agrupamentos majoritários mais $\operatorname{moderados}^{36}$, quer pela progressiva "acomodação" de partidos e sindicatos outrora mais radicais, quando eram majoritários ${ }^{37}$.

\footnotetext{
${ }^{35} \mathrm{O}$ processo foi mais difícil e repleto de crises, Por exemplo, na socialdemocracia alemã (as polêmicas entre Kautsky, Berstein, Rosa Luxemburgo, etc.) do que na Inglaterra onde o Labour Party, desde o início, se constituiu como um grupo de pressão e os partidos mais radicais (como a Federação Social- -Democrata) foram extremamente fracos e sem grande influência entre a massa de trabalhadores.

36 Este foi, por exemplo, o caso, nos Estados Unidos, do desaparecimento do IWW e da predominância da AFL. O surgimento do CIO, em 1936, fez renascer um sindicalismo
} 
A lenta adaptação das associações operárias para a luta "dentro do sistema" ganhou impulso com a extensão do sufrágio eleitoral, que abriu pela primeira vez possibilidades de uma pressão eficaz por via parlamentar. A partir daí, paulatinamente, os partidos e associações operárias foram deixando de lado os programas socialistas revolucionários, tal como tinham sido pensados nos fins do século passado.

Assim, por exemplo, na Alemanha, no Congresso de 1963, a DGB renunciou ao programa de 1949, abandonando duas reivindicações que sempre estiveram no centro das reivindicações socialistas: a nacionalização dos meios de produção e a planificação econômica. No novo programa, reivindica-se apenas o controle do poder econômico e a coordenação da política econômica. As recentes posições assumidas pela central sindical acompanharam as mudanças efetuadas no programa do Partido Socialdemocrata. $O$ aspecto saliente na nova orientação da socialdemocracia alemã é que a abolição da propriedade privada deixou de ser sua reivindicação básica. Complementarmente, a planificação econômica passou a ser exigida apenas quando necessária ("Concorrência sempre que possível; planificação sempre que necessária") ${ }^{38}$.

$\mathrm{Na}$ opinião de E. Mandel, estaria havendo uma "renúncia progressiva da socialdemocracia a seus objetivos socialistas, mesmo reformistas, e a socialdemocratização progressiva dos partidos comunistas europeus" ${ }^{\prime 39}$. A responsabilidade pelo abandono das orientações revolucionárias caberia às direções operárias tradicionais (socialistas e comunistas):

agressivo, voltado para a sindicalização dos trabalha- dores da grande indústria mas sem ideologia revolucionária. Os observadores de diferentes tendências concordam, no entanto, que a burocratização do CIO se realizou muito rapidamente. A fusão, em 1955, entre a AFL e o CIO consolidou a predominância de um tipo de sindicalismo que não questiona as bases sociais e econômicas do capitalismo americano.

${ }^{37}$ Esse tipo de desenvolvimento foi mais comum na Europa Continental, onde haviam predominado os partidos de ideologia revolucionária. Exemplos nesse sentido são fornecidos pela evolução da CGT francesa, da socialdemocracia alemã, etc..

38 Jeanne PARODI, "Les Doctrines économiques socialistes et l'action syndicale dans le mouvement ouvrier allemand d'aujourd'hui", Sociologie du Travail, julho-setembro de 1964. No mesmo sentido, ver: Burkart LUTZ, "Les Syndicats allemands au debut des années 60", Sociologie du Travail, janeiro- -março de 1964 (Tradução brasileira in: Leôncio Martins Rodrigues (org.), Sindicalismo e Sociedade).

${ }^{39}$ E. MANDEL, La Réponse Socialiste au Défi Americain, Paris, François Maspero, 1970, p. 133.
Tanto a expansão econômica neocapitalista na Europa como o esfacelamento da consciência de classe em certas camadas operárias não são o resultado de qualquer automatismo econômico nem da força toda pode- rosa e diabólica dos mass-media. Isso ocorreu em virtude das capitulações sucessivas das direções operárias tradicionais ante a sociedade burguesa ${ }^{40}$.

Mandel enfatiza, assim, o papel das lideranças. Outros autores tratando principalmente do caso da França e da Itália, onde as ideologias operárias embora em declínio conservam ainda certo vigor - preferem considerar, também de uma perspectiva socialista, os efeitos que um conjunto de mudanças econômicas e tecnológicas, ocorridas nos últimos anos, vêm exercendo sobre a classe operária ${ }^{41}$.

Não caberia, no momento, tentar uma avaliação das transformações ocorridas nas orientações políticas e sindicais do proletariado europeu, questão que coloca muitas interrogações e que, em última instância, diz respeito à própria evolução do capitalismo e das sociedades industriais contemporâneas. Alguns pontos, no entanto, necessitam ser brevemente enfatizados.

Em primeiro lugar, o declínio das ideologias operárias não implica o enfraquecimento da capacidade de barganha e pressão das organizações sindicais $^{42}$. Mais frequentemente, ocorre o contrário: o fortalecimento das

${ }^{40}$ E. MANDEL, op. cit., P. 132.

${ }^{41}$ Ver particularmente: Lucio MAGRI, "O Modelo de Desenvolvimento Capitalista e o Problema da Alternativa Proletária", Bruno TRENTIN, "Os Sindicatos Italianos e o Progresso Técnico", in: Leôncio Martins Rodrigues (org.), Sindicalismo e Sociedade, André GORZ, Stratégie Ouvrière et Neocapitalisme, Paris, Seuil, 1964; Le Socialisme Difficille, Paris, Seuil, 1967; Roger GARAUDY, A Grande Virada do Socialismo, Rio, Civilização Brasileira, 1970; Lelio BASSO, "Democracie et Nouveau Capitalisme", Les Temps Modernes, Paris, setembro-outubro de 1962; Bruno TRENTIN, "Tendances actuelles de la lutte de classe et problèmes du mouvement syndical" e Lelio BASSO, "Les Perspectives de la gauche européenne", Les Temps Modernes, Paris, fevereiro de 1967.

42 No mesmo ano em que a DGB abandonava a reivindicação básica de estatização econômica, o sindicato dos trabalhadores metalúrgicos desencadeava uma greve de grande envergadura em favor de uma nova política salarial e da redução do tempo de trabalho. Cf. Jeanne PARODI, op. cit.. Nas palavras do autor, a greve dos metalúrgicos do BadeWurtemberg, na primavera de 1963, abrangeu mais de 200 mil trabalhadores, "lembrando os mais duros conflitos da classe”. Em fins de 1971, nova greve por aumento de salário ocorreu nesta região, alcançando cerca de 500 mil trabalhadores e paralisando as principais indústrias automobilísticas alemãs. 
organizações operárias (sindicatos e partidos) se acompanha do enfraquecimento do fator ideológico. O que parece ter ocorrido é que a ação reivindicatória se apresenta desvinculada de uma concepção totalizante de mudança social, no sentido de que essa última não é vista como resultado de uma luta final que tem como objetivo a transformação do sistema de propriedade, especificamente a abolição da propriedade privada. Não necessariamente essa evolução implica o retrocesso dos valores democráticos, igualitários e socialistas que, a longo prazo, tendem a se difundir e consolidar nas sociedades industrializadas.

Em segundo lugar, o enfraquecimento das ideologias classistas não supõe o desaparecimento do conflito industrial ${ }^{43}$, das tensões e lutas que envolvem os diferentes grupos nas sociedades industriais, ainda que durante certos períodos possa ocorrer uma diminuição dos conflitos fabris, tomandose a ocorrência de greves como um de seus indicadores mais importantes ${ }^{44}$.

Em terceiro lugar, o declínio do radicalismo operário não está relacionado ao desinteresse por parte dos sindicatos pelos problemas políticos da sociedade e ao alheamento face às questões relacionadas ao desenvolvimento econômico. Isso não significa afirmar uma relação causal entre o enfraquecimento das ideologias revolucionárias e a preocupação pelos problemas mais amplos da sociedade global. Ambos os fenômenos decorrem de um conjunto de mudanças operadas tanto nas sociedades industriais ocidentais quanto nas próprias organizações sindicais e políticas da classe operária que levaram à sua consolidação, à ampliação de seu poder de controle e à participação legitimada em diferentes setores da atividade política e econômica.

43 Aron considera que os conflitos, nas sociedades industriais, caracterizam-se concomitantemente pela intensificação das reivindicações e pelo enfraquecimento dos movimentos revolucionários e da propensão à utilização da violência. Raymond ARON, $L a$ Lutte de Classes, Paris, Gallimar, 1964. Ver especialmente o capítulo: "De la lutte de classes à la satisfaction querelleuse".

${ }^{44}$ Sobre o assunto, ver principalmente K. G. C. J. KNOWLES, Strikes, a Study in Industrial Conflict, Nova York, Philosophical Library, 1952, que apresenta um minucioso estudo estatístico das greves britânicas. Para uma análise mais geral da evolução dos conflitos do trabalho, ver Jean-René TRÉATON, "Los Conflitos del Trabajo" in: G. Friedmann e P. Naville (eds.), Tratado de Sociologia del Trabajo, II vol., e Arthur ROSS, "Les Relations professionnelles aux Estats-Unis dans les dix années à venir", Sociologia du Travail, abriljunho de 1962.
$\mathrm{Na}$ medida em que se diluem as bases classistas das orientações dos grupos operários, a pressão dos sindicatos e das camadas assalariadas tende a se dirigir mais para os aspectos relacionados ao controle das decisões nos seus diferentes níveis, para a igualdade de oportunidades, para a democratização da participação, como reação às estruturas hierarquizadas e burocratizadas das grandes organizações, públicas ou privadas, econômicas, políticas e mesmo científicas e educacionais. O eixo do conflito está se deslocando do problema da propriedade privada e do lucro capitalista, da luta contra a exploração e a miséria para o do controle do Poder e obtenção de novas formas de participação ${ }^{45}$.

A discussão das características das modernas sociedades industriais sobre as quais as opiniões dos sociólogos e cientistas políticos estão longe de convergir - levar-nos-ia muito além dos objetivos do presente trabalho. Limitamo-nos, nas páginas que se seguem, à apreciação das variáveis que destacamos anteriormente e de seus efeitos sobre as condutas e ações operárias na situação atual da Europa Ocidental.

$\mathrm{O}$ primeiro aspecto a ser visto relaciona-se às mudanças na tecnologia industrial e seus reflexos sobre a administração das empresas, a composição profissional da força de trabalho e, correlatamente, em algumas das orientações políticas e valorativas dos trabalhadores. Consideremos inicialmente as transformações ocorridas do ponto de vista de seus efeitos sobre a consciência operária, as atitudes ante o trabalho, a solidariedade profissional e as formas de ação sindical.

Embora a evolução da tecnologia industrial - com o sistema de produção em série - atuasse no sentido do enfraquecimento da anterior

${ }^{45}$ A. TOURAINE considera que é mais útil atualmente, para as sociedades altamente desenvolvidas, falar de alienação do que de exploração (La Société Post-Industrielle, ver especialmente os caps. "La Société Programmée et sa Sociologie" e "Anciennes et Nouvelles Classes Sociales"). A. GORZ julga que a luta contra a miséria não pode mais servir de fundamento para a luta pelo socialismo (Stratégie Ouvrière et Néocapitalisme). Observa Mothé, por sua vez, que "a fome, a exploração, a humilhação que assombraram a classe operária durante tantas gerações continuam a ser o quadro ideológico e o modo de expressão do proletariado. A maior parte dos aspectos da vida dos trabalhadores se expressam ainda nesses termos. Entretanto, constatamos todos os dias que, para o mundo do trabalho, não são tanto a miséria ou a inferioridade social que contam mas a alienação no seu sentido mais profundo e mais total”. D. MOTHÉ, Militant chez Renault Paris, Seuil, 1965, p. 14. 
solidariedade operária, organizada em torno do ofício, o aumento numérico do proletariado (ao lado de outras mudanças ocorridas no sistema político) ampliaram a influência dos trabalhadores no conjunto da sociedade, transformando-os numa força eleitoral expressiva, o que implicou o relativo deslocamento das ações operárias do interior das fábricas para o da sociedade global. Do ponto de vista da consciência operária, as transformações assinaladas significam o enfraquecimento da "consciência de produtor". Os novos trabalhadores - inseridos no sistema de produção em série e pessimistas quanto às suas possibilidades de alterar o sistema técnico e hierárquico a que estão submetidos - tendem a dirigir predominantemente suas reivindicações para o terreno de mais consumo e lazer (aumentos de salário, redução da jornada de trabalho e do limite de idade para a aposentadoria, maior período de férias, etc.).

Estudo realizado com trabalhadores metalúrgicos franceses ressalta que o tipo de atitude predominante entre operários semiqualificados é o de "resignação", embora os autores da pesquisa observem também comportamentos de fuga da condição operária e de militância. O socialismo, quando aparece, é para esses trabalhadores principalmente "a igualdade de oportunidades", contrastando com a ideia que dele faziam as antigas elites operárias. Esta distinção parece importante porque matiza diferentes modos de rejeição do sistema industrial que, amiúde, se confundem sob a denominação geral de "anticapitalismo". Valeria a pena, apesar de relativamente longa, transcrever a caracterização que os autores fazem dos militantes operários do antigo sindicalismo de ofício:

No seu espírito, a sociedade anticapitalista não se distinguiria pelo fato de os filhos dos operários poderem ter, no futuro, oportunidades que eram tradicionalmente reservadas aos filhos dos privilegiados, nem mesmo pelo fato de que os operários, dotados das capacidades e energias necessárias, disporiam, para eles mesmos, das chances de chegar à situação e às funções de diretor, de estadista, saindo de suas posições e abandonando a oficina onde permaneceriam seus colegas de trabalho fixados às suas funções de último executante. O socialismo não era, a seus olhos, a sociedade de oportunidades iguais para todos. O militante daquela época se dizia: uma vez que sou eu que faço o trabalho produtivo e que sou eu, pelo esforço de minhas mãos, que asseguro a base material sobre a qual desabrocha a verdadeira vida do homem, é a mim que devem pertencer as riquezas, os conhecimentos, o espírito; para mim cabem a direção e a administração das oficinas, da fábrica, da economia e da sociedade ${ }^{46}$.

O desaparecimento dos antigos ofícios e a preponderância do sistema de trabalho parcelado agiram no sentido do enfraquecimento da antiga consciência profissional e mudaram o eixo da crítica operária ao sistema capitalista. Afetaram, principalmente, a relação entre o operário e o trabalho, criando uma atitude instrumental ante o trabalho fabril ${ }^{47}$.

No entanto, se a desqualificação profissional e o desaparecimento da consciência de produtor debilitaram a coesão interna da classe e tornaram mais difícil a aplicação das táticas de ação direta, o aumento da importância social e política da classe propiciou melhores condições para a atuação eleitoral e para a obtenção de vantagens trabalhistas por intermédio da legislação ou da pressão sobre o parlamento e o governo. As concepções socialistas passaram a enfatizar mais a estatização, o planejamento, o desenvolvimento econômico, a democratização do Estado e a abertura de oportunidades do que a gestão da economia pelos próprios "produtores".

Os avanços da automação tenderão a acarretar outras modificações relevantes na situação sumariada acima, alterando a composição profissional da força de trabalho e a imagem tradicional do "proletariado", criada nas fases anteriores da industrialização. Principalmente a automação deverá pôr fim a uma tendência que persistentemente acompanhara o progresso da tecnologia industrial: a desqualificação do trabalho decorrente do parcelamento das tarefas. A proporção de trabalhadores dotados de alta qualificação, encarregados da supervisão, manutenção e reparação dos equipamentos automatizados tenderá a aumentar. Por sua vez, os problemas situados pela automação, com a especialização crescente do equipamento, acentuará as tendências na direção de uma integração maior do trabalhador à

${ }^{46}$ André ANDRIEUX e Jean LIGNON, L'Ouvrier d'aujourd'hui, Paris, Ed. Gonthier, 1966, p. 59.

${ }^{47}$ Encontramos esse tipo de atitude entre trabalhadores de uma indústria automobilística de São Paulo. Cf. Leôncio Martins RODRIGUES, Industrialização e Atitudes Operárias. Os resultados de uma pesquisa inglesa realizada aproximadamente na mesma época sugerem que essa orientação "instrumental" é mais geral, relacionada à natureza repetitiva e desinteressante das tarefas realizadas pelos operários. Cf. John GOLDTHORPE, David LOCKWOOD, Frank BECHHOFER e Jennifer PLATT, The Affluent Worker: Industrial Altitudes and Behaviour, Cambridge University, 1970. 
empresa, ocasionando modificações nas formas de remuneração e avaliação do rendimento (não mais individualmente mas por equipes), mudando o tipo de relacionamento entre a administração e os operários, aumentando a importância dos grupos de assalariados dos escritórios de estudo e planejamento, etc.. O progresso da automação, por outro lado, criará novas reivindicações relacionadas mais especificamente à estabilidade no emprego, ao salário anual garantido, à avaliação do rendimento, à promoção, à participação nos ganhos de produtividade, além de levar ao desaparecimento de antigos ofícios, à criação de novas profissões que exigem qualificação mais elevada do que nas empresas não automatizadas ${ }^{48}$.

As opiniões dos diferentes autores sobre os efeitos da automação nas orientações operárias nem sempre são coincidentes. Entretanto, concordam geralmente em considerar que, ultrapassados os momentos de sua implantação (em que se nota a renovação de reivindicações sindicais relacionadas à defesa do emprego e da profissão), a automação deverá acarretar uma melhoria nas relações industriais, em razão da menor fadiga física, das melhores condições ambientais, dos salários mais elevados, etc.. Outros observadores sugerem, por outro lado, que a automação e o progresso técnico na indústria poderão conduzir ao aparecimento de um novo ativismo sindical, concentrado nos problemas da empresa (um "sindicalismo de empresa") que teria alguns pontos de contacto com o velho anarcossindicalismo, tal como o "apoliticismo" e a gestão operária ${ }^{49}$.

Como quer que seja, para os propósitos da presente discussão, interessa ressaltar a diminuição da população operária, fenômeno que, de fato, não está vinculado apenas ao avanço da automação, mas ao progresso

${ }^{48}$ As afirmações relativas à automação estão baseadas principalmente nas seguintes obras: F. POLLOCK, La Automación: Sus Consecuencias Economicas y Sociales, Buenos Aires, Sudamerica, 1959; G. HARTMANN, Le Patronat, les Salariés et l'Etat face à l'Automation, Neuchatel, Ed. de la Baconnière, 1956; S. LILLEY, Automatizacion y Progreso Social, Madrid, Taurus Ediciones, 1959; F. C. MANN e L. R. HOFFMAN, Automation and the Worker, Nova York, Henry Holt and Co., 1960; P. NAVILLE, "La structure de l'emploi et l'automation"; Paul EINZIG, "Automation et relations industrielles", Conséquences Sociales de l'Automation, número do Bulletin International des Sciences Sociales, vol. X, n 1, 1958, Unesco; H. R. BOWEN e G. L. MANGUN, Automação e Progresso Econômico (eds.), Rio, Zahar, 1969; J. DIEBOLD, Autámation, the Advent of the Automatic Factory; D. Van Nostrand, 1952.

${ }^{49}$ S. MALLET, op. cit. Ver também do mesmo autor, "Socialism and the New Working Class", International Socialist Journal; n. ${ }^{\circ}$ 8, abril de 1965, pp. 159 a 161. técnico em geral. Nos principais países industrializados, do prisma do número de aderentes, os sindicatos tendem à estagnação ${ }^{50}$. Para os antigos partidos operários europeus, as tendências atuais da tecnologia industrial (entre outros fatores) situam novos problemas: a camada social, sobre a qual se apoiaram tradicionalmente, tende a se reduzir. A longo prazo, se tais partidos pretenderem manter as posições atualmente adquiridas, terão que deixar de ser partidos operários para tentar atrair as novas camadas assalariadas. Nessa hipótese, deverão perder seu caráter de classe e sua ideologia obreirista. Do ponto de vista dos sindicatos, a diminuição da população operária deverá acarretar o decréscimo de sua importância na sociedade global. A expansão do sindicalismo, para o futuro, dependerá grandemente da possibilidade de incorporar os empregados, técnicos e white-collars da nova classe média assalariada ${ }^{51}$.

Não necessariamente as tendências assinaladas redundarão no debilitamento do poder de pressão dos sindicatos operários sobre as empresas e o sistema econômico, pois grupos relativamente pequenos de trabalhadores, em indústrias altamente sofisticadas do ponto de vista do equipamento e de sua organização, podem situar-se em posições altamente favoráveis para reivindicar e pressionar as direções das empresas e o Estado. Contudo, o peso eleitoral do proletariado industrial deverá diminuir.

O fenômeno da automação sumariado anteriormente, embora indique as tendências prováveis da evolução futura, está longe de ilustrar a realidade atual da classe operária dos países desenvolvidos ${ }^{52}$. A maior parte do proletariado fabril continua localizada nos estabelecimentos industriais de produção em série, em que predomina o trabalho parcelado, repetitivo, realizado por operários semiqualificados. De modo geral, esses trabalhadores

50 “... os efetivos sindicais, que tinham dobrado praticamente entre 1939 e 1955 , permaneceram, no decorrer dos anos seguintes, a um nível estável, para acusar em seguida uma diminuição de 100 a 500 mil membros segundo as estimativas". Jacques DOFNY, "Os Sindicatos Americanos e a Automação", in: Leôncio Martins Rodrigues (org.), Sindicalismo e Sociedade, p. 175.

${ }^{51}$ Estudo relativamente recente sobre a sindicalização de white-collars em diferentes países indica que os êxitos sindicais não têm sido de magnitude semelhante aos alcançados na organização dos blue-collars. Cf. Adolf STURMTHAL (ed.), Whitte-Collar Trade Unions, Chicago, Univ. of Illinois, 1967.

${ }^{52} \mathrm{P}$. Naville refere-se de $6 \%$ a $10 \%$ de trabalhadores atingidos pela automação.Cf. "Structure de l'Emploi et l'Automation", Bulletin International des Sciences Sociales. 
continuam a representar a massa de filiados aos grandes sindicatos e de eleitores dos partidos socialistas ou comunistas. São, no entanto, trabalhadores cujo processo de evolução tecnológica se realiza no sentido de seu enfraquecimento enquanto classe, "trabalhadores que não têm a Historia a seu favor".

As transformações na tecnologia fabril não significam apenas modificações na composição profissional da classe e na importância dos diferentes grupos operários no interior da classe. Afetam igualmente a percepção da empresa enquanto sistema, isto é, a ideia que o trabalhador tem de seu papel na produção e das funções da direção. Já ressaltamos que o progresso na tecnologia industrial aumenta a importância dos grupos não operários no funcionamento geral da empresa (disposição das máquinas e postos de trabalho, seleção da matéria-prima, controle da qualidade, estudos de mercado, publicidade, cálculos de rentabilidade, pesquisas de novos produtos, etc.). Em poucas palavras, a empresa moderna alterou o meio sócio-profissional sobre o qual se baseavam as concepções tradicionais de "controle operário", de gestão e de reapropriação dos meios de produção. A evolução técnica - pelo menos até a automação - processou-se em detrimento da autonomia e da capacidade de decisão do trabalhador, aumentando sua alienação e heteronomia e beneficiando a direção, ou melhor, a estrutura de autoridade empresarial ${ }^{53}$. Os órgãos especializados de comando tornaram-se insubstituíveis, qualquer que seja a forma da propriedade (privada, semiestatal ou estatal).

A direção se assenhorou de uma funcionalidade, de um saber técnico que não mais está ao alcance do simples operário, que sozinho não é mais produtivo. No quadro de um sistema hierárquico que se justifica (ou busca justificar-se) não mais em razão da propriedade (ou do capital) mas de seus

\footnotetext{
53 "Nas fábricas racionalizadas, as tarefas repetitivas são estritamente organizadas pelos gabinetes técnicos, por meio de uma série de fichas de instrução, imperativas e minuciosas, e de dispositivos técnicos obrigatórios (montagens, etc.). No caso dos trabalhadores em cadeia (sobre cadeias de montagem e juntura, por exemplo), estas tarefas são particularmente elementares e encontram-se especialmente divididas. Quer num caso, quer no outro, não exigem, em geral, mais do que uma rápida aprendizagem e, em seguida, um tempo variável de habituação a fim de atingirem e manterem o ritmo e o rendimento que os gabinetes determinarem". G. FRIEDMANN, O Futuro do Trabalho Humano, Lisboa, Moraes Editores, 1968, pp. 226-7. Ver também, do mesmo autor, Problemas Humanos del Maquinismo Industrial, Buenos Aires, Sudamerica, 1956; El Trabajo Desmenuzado, Buenos Aires, Sudamerica, 1958.
}

conhecimentos, de sua "funcionalidade", a contestação operária à estrutura de autoridade da empresa não encontra outra alternativa senão a reivindicação da redução da jornada de trabalho, de melhores salários, ou seja, de maior lazer e consumo. Daí porque os apelos socialistas clássicos tenham seu atrativo diminuído face ao ceticismo dos trabalhadores quanto às possibilidades de modificação de um sistema de organização do trabalho que tende a se restabelecer mesmo depois dos maiores conflitos ${ }^{54}$. Daí porque o problema da propriedade esteja cada vez menos no centro das reivindicações dos trabalhadores pois o sistema hierárquico se mantém quer o "patrão" seja o proprietário privado ou o Estado 55 .

Galbraith considera que nas "empresas amadurecidas" os interesses dos sindicatos tendem a coincidir com o que denomina de "tecnoestrutura"56. É possível que as negociações coletivas sejam mais facilmente conduzidas quando, na direção, estão os administradores profissionais em vez dos proprietários. Contudo, a atenuação do conflito e o aumento da "racionalidade" na discussão entre sindicato e empresa já vinham ocorrendo mesmo quando predominavam as "companhias empresariais". Não parece, portanto, que as modificações na orientação dos sindicatos e dos trabalhadores estejam relacionadas basicamente à ascensão da "tecnoestrutura" (supondo que assim seja) mas a modificações mais amplas nas sociedades industriais que começaram antes das "companhias amadurecidas". No âmbito da empresa, fator importante parece ser os fundamentos da legitimidade dos postos de comando. Desse ângulo, inegavelmente, as "companhias amadurecidas" favorecem o lado "funcional" e "impessoal" da estrutura de autoridade e debilitam as ideologias operárias que se nutriam no meio técnico e social das pequenas

${ }^{54}$ Veja-se, nesse sentido, as amargas reflexões de Daniel MOTHÉ sobre a alienação do operário, envolvido pela "lógica" e pela "racionalidade" da empresa (e também dos aparelhos sindicais) das quais dificilmente consegue escapar.

55 "As massas assalariadas, estão agora muito menos dominadas pelo sentimento de exploração relativamente à propriedade privada dos meios de produção do que pelo sentimento de alienação que leva à obediência passiva, à negação das necessidades elementares, inerentes à maioria dos indivíduos, de independência e de iniciativa". Georges FRIEDMANN, "Tendencias de Hoy, Perspectivas de Manãna", in: G. Friedmann e P. Naville (eds.), Tratado de Sociologia del Trabajo, I vol., p. 391.

56 John K. GALBRAITH, O Novo Estado Industrial, Rio, Civilização Brasileira, 1968, principalmente os capítulos: "O Sistema Industrial e o Sindicato" - (I e II). 
oficinas, quando os trabalhadores qualificados (os "operários profissionais polivalentes", na terminologia francesa) estavam no centro da organização do trabalho ${ }^{57}$. As transformações no sistema de trabalho e de funcionamento das empresas não eliminam as reivindicações operárias, o antagonismo entre os lucros e os salários, entre os que mandam e os que obedecem. Porém, alteram as formas de consciência operária, a percepção que os trabalhadores têm de seu trabalho, de sua importância no processo de produção, assim como sua visão do mundo industrial. Assim fazendo, deslocam a ênfase das aspirações e reivindicações operárias.

As atitudes dos grupos operários ante a empresa e o trabalho fabril são afetadas ainda pelo meio social de recrutamento da força de trabalho. No passado, o avanço do capitalismo significou a proletarização crescente de camponeses, de artesãos e de uma pequena-burguesia independente. Este processo chegou ou está chegando ao fim. O setor primário - com ligeira exceção para a França e Itália onde os camponeses constituem ainda um setor importante embora decrescente da força de trabalho - não mais constitui o grande estoque de recrutamento de mão de obra à disposição da indústria.

Nas condições presentes, as novas gerações de trabalhadores que adentrarem a indústria, encontrar-se-ão em posição bastante diferente da de seus pais ou avós, com sindicatos estáveis e legitimados, e possuindo um conjunto de vantagens sociais (férias, aposentadoria, redução da jornada, melhor ambiente de trabalho, salários mais elevados, etc.) inexistente no passado. Mais concretamente, dadas as condições atuais de trabalho e os níveis salariais das grandes empresas, a incorporação à indústria não deverá ter o mesmo sentido de degradação social que significou para as primeiras gerações de trabalhadores. Quaisquer que sejam os novos problemas que tenha que enfrentar, em razão do progresso técnico ou de outras mudanças no interior das sociedades industriais, a nova classe operária disporá de melhores condições para fazê-lo.

Porém, na verdade, as tendências globais de deslocamento da força de trabalho não vão na direção da "proletarização crescente" da população mas na da formação de novos estratos intermediários, de uma nova classe média assalariada que deverá localizar-se principalmente no setor terciário.

${ }^{57}$ Cf. A. TOURAINE, "La Organización Profesional de la Empresa" e P.NAVILLE e P. ROLLE, op. cit.
As transformações que se operarem nas sociedades desenvolvidas, de outro ponto de vista, ao contrário do passado, não serão tão dependentes do jogo "espontâneo" das forças de mercado e das ações e reações do patronato e dos trabalhadores. As mudanças futuras estarão, em larga medida, condicionadas pela ação do Estado e de grupos não propriamente econômicos, tais como certas camadas que tiveram sua influência e prestígio aumentados no decorrer desses últimos anos (cientistas, técnicos, administradores, etc.). Mais precisamente, o desenvolvimento será relativamente menos dependente do esforço de enriquecimento privado das classes burguesas, o que situa a questão do Poder e do controle do sistema político e decisório como um dos problemas centrais das sociedades dominadas pelas grandes organizações privadas ou estatais. Para as camadas de trabalhadores e para os novos grupos assalariados, trata-se de um desafio relativamente recente, cuja resposta não poderá ser encontrada na reafirmação de uma ortodoxia doutrinária cuja terapia proclamada no passado encontra, no presente, poucas possibilidades de aplicação e, menos ainda, de alcançar os resultados esperados.

Do prisma do estudo do comportamento da classe operária nas sociedades contemporâneas, outro fator importante a se ter em conta é a incorporação dos trabalhadores a uma economia de consumo de massas aliada aos efeitos dos novos meios de comunicação que vêm agindo no sentido da corrosão dos particularismos classistas. Como tem sido notado, os trabalhadores fora da fábrica tendem a diferenciar-se cada vez menos de outras camadas sociais no que tange às formas de consumo e de lazer. Certos modos de sentir, pensar e agir que estiveram, no decurso da industrialização capitalista, estreitamente associados a uma dada classe social, tendem a desaparecer nas sociedades industriais de massas, contribuindo, por sua vez, para enfraquecer os conteúdos ideológicos e culturais específicos do proletariado industrial. Embora não acarrete o desaparecimento das diferenças entre as camadas sociais quanto ao tipo de trabalho, nível e qualidade da formação técnica, etc., esse processo de massificação do consumo tende a enfraquecer as fronteiras culturais que transformavam os 
diferentes grupos profissionais em formações sociais mais amplas, mais homogêneas e coesas, com forte consciência de si, isto é, em classe sociais ${ }^{58}$.

Em suma, as transformações ocorridas nas sociedades europeias, a partir mais particularmente da reconstrução do após-guerra, implicaram na democratização do sistema político e na consolidação de valores igualitários. Esses processos não significam o fim dos conflitos industriais mas enfraquecem seu conteúdo "classista". Os problemas básicos das sociedades desenvolvidas do Ocidente não são mais aqueles resultantes da presença de uma maioria de trabalhadores espoliados e miseráveis, de uma classe, mas de camadas inteiras de assalariados modernos, gozando de relativo bem-estar material ${ }^{59}$ e inseridos no sistema hierárquico das grandes empresas, nas linhas de produção ou nos escritórios, nos aparelhos burocráticos estatais, para os quais a eventual mudança na forma jurídica da propriedade não melhora sua situação no trabalho e na sociedade se não vier acompanhada de outras modificações que impliquem a democratização do Poder, a ampliação da participação nos vários níveis de decisão, novos sistemas de valores, enfim, de um novo estilo de vida, diferente daquele que a "racionalidade" e a "lógica" da empresa, da burocracia e da civilização industrial tendem a impor.

Olhado à distância, vemos que o socialismo europeu resultou das condições particulares que estiveram ligadas a um momento histórico da industrialização capitalista. Na medida em que certas tendências que levaram à massificação e à democratização da sociedade começaram a predominar (nos EUA antes de qualquer outra nação) o radicalismo operário ligado a uma visão classista do mundo, implicando sistemas axiológicos conflitantes, entrou em declínio.

Apesar disso, é pouco provável que os problemas surgidos com a massificação da sociedade europeia sejam equacionados como o foram nos Estados Unidos.

${ }^{58}$ Para uma análise geral das classes sociais nas sociedades industriais desenvolvidas, cf., T. B. BOTTOMORE, As Classes na Sociedade Moderna, Rio, Zahar, 1968.

${ }^{59}$ Isto não significa dizer que não existem camadas pobres nos países desenvolvidos. Porém, são minoritárias no conjunto da população e constituídas geralmente por trabalhadores estrangeiros. Do prisma da ortodoxia proletária do século passado, e da luta contra a miséria, um dos problemas dos dias de hoje é como fazer triunfar a revolução de uma minoria pobre contra uma maioria economicamente acomodada.
A história do desenvolvimento dos diferentes países mostra que os momentos iniciais de formação da sociedade industrial são cruciais para sua configuração ulterior. As instituições que superam esses momentos (deslocamento de grandes populações para a indústria e para os centros urbanos, supremacia do setor secundário no PNB, formação do Estado nacional, etc.) demonstram posteriormente notável persistência. Vista a questão do prisma que nos interessa, isto é, do movimento sindical, percebese que as organizações operárias que conseguiram se expandir e ultrapassar esses períodos de legitimação dos sindicatos, de democratização do sufrágio, etc., persistem até hoje, apesar das transformações que sofreram.

As fases iniciais do movimento operário são marcadas pela existência de numerosas associações rivais que oferecem variadas formas de ação operária, que defendem diferentes concepções da sociedade futura, que preconizam (e às vezes aplicam) táticas de luta diferentes. A maior parte dessas organizações tem vida curta. No entanto, algumas sobrevivem e se tornam hegemônicas. As razões particulares relacionadas à capacidade de sobrevivência de cada uma não poderiam ser analisadas aqui. Claro está que, de um modo geral, foram mais "adaptadas" ao meio em que deveriam viver, isto é, às características da sociedade e da classe operária nacional. Assim, por exemplo, o Partido Trabalhista Inglês, depois de sua formação, praticamente não teve mais rivais sérios como o partido dos trabalhadores ingleses. A Federação Social-Democrática de Hyndman (1884), apesar de sua vida relativamente longa, não teve influência importante sobre as massas operárias da Grã-Bretanha ${ }^{60}$. A mesma afirmação poderia ser feita para o Partido Trabalhista Independente que situava como objetivo final a "propriedade coletiva dos meios de produção", embora não estivesse baseado na luta de classe. O VII, contudo, desempenhou um papel relevante na formação do Partido Trabalhista. O Partido Socialista Britânico, surgido em 1911 com a fusão de uma fração da Federação Social-Democrática com outros grupos, ao se filiar ao Partido Trabalhista, possuía apenas $10 \mathrm{mil}$ membros ${ }^{61}$. O Partido Comunista Inglês, malgrado seus esforços de

60 Segundo Hobsbawm, a Federação Social-Democrática foi a principal corrente representante do marxismo na Inglaterra entre os anos de 1880 e 1920. Ver "Hyndman and the SDF", in: Labouring Men, Studies in the History of Labour.

${ }^{61}$ G. D. H. COLE, History of the Labour Party from 1914, Londres, George Allen e Unwin, 1948, p. 9. 
penetração no movimento sindical e as repetidas mudanças de tática, nunca chegou a ter influência entre a massa de trabalhadores a ponto de ameaçar a supremacia do Partido Trabalhista Britânico e orientação "gradualista" dos grandes sindicatos.

Nos EUA, a American Federation of Labor subsiste até hoje. Pelo conservantismo de sua orientação, foi vigorosamente combatida por diferentes grupos e tendências. Após o desaparecimento do IWW, não teve mais concorrentes no interior do sindicalismo americano até o surgimento de CIO (1935), com o qual se fundiu em 1955. Na Alemanha, a socialdemocracia, e os sindicatos a ela ligados, estabeleceu seu controle sobre os trabalhadores por volta do começo do século. Apesar da concorrência do Partido Comunista (a partir dos anos 20 até a ascensão do nazismo em 1933) permaneceu como a corrente dominante no movimento operário e ressurgiu triunfante no após-guerra. Nos demais países, como Áustria, Bélgica, Holanda, Países Escandinavos, os sindicatos e partidos socialistas mantêm até hoje sua posição hegemônica.

A situação na França e Itália parece mais complexa e menos definida. Dos países industrializados da Europa Ocidental, são as sociedades que estão passando por transformações mais profundas do ponto de vista de sua modernização industrial, concentração de capital, transferência de populações do setor primário, etc.. Contudo, apesar da concorrência do sindicalismo cristão, a CGT e a CGIL mantêm-se, desde o após-guerra, como as centrais sindicais majoritárias.

Essas observações não se destinam a afirmar a impossibilidade de mudanças, de natureza variada, nas organizações majoritárias nem tampouco a excluir a emergência de outras tendências sindicais. Elas sugerem, porém, que as associações sindicais quando se transformam em organizações de massa, demonstram grande longevidade. As correntes de oposição às lideranças estabelecidas geralmente têm tido êxitos bastante $\operatorname{limitados}^{62}$. A persistência das organizações majoritárias indica que elas têm

\footnotetext{
${ }^{62} \mathrm{Na}$ Inglaterra, de 128 eleições envolvendo 24 sindicatos, há somente dois exemplos em que o candidato de oposição ao cargo de secretário-geral foi vencedor. Cf. W. GALENSON, Trade-Union Democracy in Western Europe, p. 52. Lembremos que os candidatos são eleitos vitaliciamente. No entanto, em outros países em que a vitaliciedade não existe, os que
}

sido capazes de se adaptar às transformações ocorridas no interior da sociedade (mudanças na composição profissional da classe, na tecnologia industrial, etc.) e de responder, de algum modo, às expectativas da massa de aderentes $^{63}$. Como as mudanças sociais e políticas nesses países geralmente têm-se dado gradualmente, as lideranças das organizações hegemônicas dispõem de tempo suficiente para se adaptar a elas e se apresentar como os canais pelos quais passam as novas reivindicações das camadas assalariadas $^{64}$. Em outras palavras: a partir de certa etapa de seu crescimento, transformam-se elas próprias em elementos da situação, em instituições integrantes da própria dinâmica (e estabilidade) da sociedade industrial desenvolvida ${ }^{65}$.

Assim sendo, malgrado a "americanização" da Europa Ocidental, cumpre observar que ela se efetua sobre um fundo cultural e institucional em muitos aspectos divergente daqueles envolvidos no desenvolvimento norte-americano. Mais concretamente, os grandes partidos europeus de base operária - que na sociedade americana não conseguiram firmar-se - serão quase inevitavelmente participantes das mudanças futuras.

ocupam postos de comando nos grandes sindicatos consolidados dificilmente perdem uma eleição. Na realidade, na maior parte das vezes, não têm opositores.

${ }^{63}$ A guisa de ilustração, notemos que a maioria dessas organizações sobreviveu a duas guerras mundiais e a crises econômicas profundas.

${ }^{64}$ É possível que o debilitamento das motivações ideológicas de adesão aos sindicatos esteja relacionado à persistência das organizações majoritárias. Os trabalhadores adeririam a elas principalmente pelo fato de se tratar de "grandes organizações", em melhores condições de defender seus interesses concretos. A adesão a organizações minoritárias envolve motivações de natureza ideológica mais profundas. Os trabalhadores fabris, ao contrário dos grupos intelectuais, necessitam de associações que possam atender necessidades "materiais" mais imediatas.

${ }^{65}$ Naturalmente, a questão poderia ser analisada do prisma da persistência de estruturas organizatórias e do fenômeno burocrático, aproximando-se da análise clássica de Michels nos Partidos Políticos da lei de ferro da formação das oligarquias internas bem como do monopólio das informações e das habilidades de liderança, como acentua S. M. Lipset no artigo "O Processo Político nos Sindicatos Operários". (El Hombre Político, Buenos Aires, Eudeba, 1963). Esse tipo de análise, fascinante sob múltiplos aspectos, escaparia ao escopo deste trabalho. Para uma apreciação mais geral das organizações sindicais na sua fase de estabilidade (ou de "afluência"), os estudos de Richard A. LESTER, As Union Mature, Nova Jersey, Princeton University Press, 1966 ( $3^{\mathrm{a}}$. ed.), e de William A. MYERNIK, TradeUnions in the Age of Affluence, Nova York, Randon House, 1962 (2 ${ }^{\mathrm{a}}$. ed.), oferecem dados e sugestões importantes. 


\section{PARTE II}

\section{CLASSE OPERÁRIA E} SOCIEDADE INDUSTRIAL NO BRASIL

\section{Introdução}

O objetivo desta parte do trabalho é a análise das orientações sindicais, políticas e valorativas dos trabalhadores industriais brasileiros. Não se pretende aqui um estudo da organização sindical. Da bibliografia existente ${ }^{1}$ este aspecto tem sido, entre os estudos sobre o proletariado no Brasil, relativamente bem investigado, talvez por se relacionar com a parte mais institucionalizada do movimento sindical e envolver uma faceta da ação do Estado ${ }^{2}$.

Não constitui, igualmente, objeto sobressalente das preocupações desta segunda parte, a investigação da história do sindicalismo e do movimento operário no Brasil, embora muitos pontos do passado permaneçam ainda obscuros ${ }^{3}$.

Interessa-nos, sobretudo, buscar estabelecer os fatores relevantes, de natureza mais ampla, ligados à formação da classe e a algumas de suas características, que possibilitam estabelecer algumas hipóteses referentes às alternativas possíveis de orientação dos trabalhadores, de natureza sindical, política e ideológica. Este desiderato implica em considerar certas questões

Ver: Leôncio Martins RODRIGUES, "Bibliografia Sobre o Sindicalismo e os Trabalhadores Industriais no Brasil. Notas para um Esquema Explicativo", I Encontro Internacional de Estudos Brasileiros, Instituto de Estudos Brasileiros (USP), São Paulo, 1971. (Publicado também nos Cadernos $n^{\circ} 4$, Centro de Estudos Rurais e Urbanos, São Paulo, 1971).

Em nossa opinião, a melhor exposição sobre os aspectos jurídicos e legais relativos à intervenção estatal na área trabalhista e o tipo de estrutura sindical daí resultante encontra-se em Evaristo MORAES FILHO, O Sindicato Único no Brasil, Rio, Editora "A Noite", 1966. Por outro lado, o livro de José Albertino RODRIGUES, Sindicato e Desenvolvimento no Brasil, (São Paulo, Difusão Européia do Livro, 1968) oferece uma descrição bastante detalhada e informativa do funcionamento da organização sindical no Brasil.

Sobre os primórdios do movimento sindical brasileiro, ver Azis SIMAO, Sindicato e Estado, São Paulo, Dominus Editora, 1966. de natureza mais ampla, ligadas ao processo de formação da sociedade industrial no Brasil.

Nessas condições, a descrição circunstanciada da história do sindicalismo não é nossa intenção. O objetivo dessa parte é destacar os fatores cruciais, de natureza estrutural e histórica, que afetam o comportamento dos trabalhadores, suas orientações políticas, sindicais e valorativas, assim como os meios de pressão de que dispõem. Esses fatores são de natureza bastante variada. A hipótese básica, que orientará a exposição, é de que o movimento operário não pode ser analisado como resultado das características da tecnologia, do sistema de Poder, do meio social, etc., consideradas isoladamente. A partir dessa hipótese, nossa intenção foi procurar os efeitos de um conjunto de múltiplas variáveis sobre as orientações da classe operária, o que nos obrigou a lidar com problemas que escapam de nosso campo de especialidade. Nesses casos, procuramos nos apoiar nos estudos e pesquisas efetuados por outros especialistas. 


\section{CAPÍtulo III \\ SINDICALISMO E IDEOLOGIAS OPERÁRIAS}

\section{Populismo e Classe Operária}

Três aspectos parecem particularmente marcantes para quem observa o movimento operário brasileiro: no plano profissional, a fraqueza do sindicalismo e sua dependência dos poderes públicos; no plano políticopartidário, a inexistência de partidos operários de massa; e, no plano ideológico, a predominância do populismo sobre as ideologias socialistas.

Esses três aspectos estão mutuamente correlacionados e, na realidade, expressam a fraqueza sindical, política e social do proletariado industrial brasileiro, sua heteronomia organizatória, sua reduzida capacidade de atuação autônoma ante as empresas ou ante o Estado.

Na Europa, nos principais países industrializados, já pelo começo do Século XX, os sindicatos haviam alcançado relativa capacidade de pressão política e de defesa ante os empregadores. No Brasil, mesmo hoje, os sindicatos não têm influência semelhante, apesar da importância adquirida pelo valor da produção industrial no conjunto do sistema econômico. Por outro lado, como assinalamos na Primeira Parte deste trabalho, o avanço da industrialização europeia marchou pari passu com a emergência de partidos operários, que lograram converter-se em organizações de massas. No Brasil, excetuando o curto período de 1945 a 1947, quando o PCB obteve alguns êxitos eleitorais ${ }^{1}$, em nenhuma outra ocasião a política nacional foi marcada pela presença de um "partido operário". O PCB, nesse sentido, nem de longe pode ser equiparado aos grandes partidos socialdemocratas, trabalhistas ou comunistas da Europa.

${ }^{1}$ É difícil determinar a composição social do eleitorado do PCB no seu período de legalidade. É possível que parte da votação que obteve tenha sido recolhida dos setores de classe média baixa, embora, em São Paulo principalmente, uma parte dos trabalhadores fabris possa ter votado pelos candidatos comunistas. Uma pesquisa sobre a votação operária no período considerado sugere que o PCB obteve mais votos nos velhos bairros operários, entre trabalhadores mais qualificados e urbanizados enquanto o PTB teve maior penetração entre os trabalhadores de mais baixa qualificação e de origem rural. Cf. Azis SIMÃO "O Voto Operário em São Paulo" in: Anais do I Congresso Brasileiro de Sociologia, São Paulo, Sociedade Brasileira de Sociologia, 1955.
Ademais, nos países de antiga industrialização, a participação política operária exprimiu-se tipicamente de modo "classista", orientada por ideologias de reformulação da ordem social. O conflito entre o capital e o trabalho marcou profundamente a formação das sociedades europeias. Entre nós, a emergência política do proletariado industrial efetuou-se sob ideologias de tipo populista, sob a influência de líderes políticos originários das camadas superiores ${ }^{2}$.

$\mathrm{Na}$ verdade, o proletariado, enquanto classe, esteve ausente dos eventos políticos mais marcantes da história brasileira (a Proclamação da República, os movimentos políticos da década de 20, a Revolução da Aliança Liberal, a redemocratização do país depois da II Guerra, etc.).

Na década de 1950 houve a reativação da militância operária, o aumento do número de sindicalizados e a ocorrência de movimentos grevistas de envergadura, especialmente em São Paulo nos anos de 1952, 1953 e 1957. Em agosto de 1954, quando do suicídio de Getúlio Vargas, ocorreram grandes manifestações populares e operárias, possivelmente as maiores a que o país tenha assistido.

Conviria nos determos um pouco mais nesses fatos. As greves da década dos cinquenta, para o ambiente industrial e social brasileiro, foram de grande importância. Do ângulo de uma visão militante da classe, elas são fontes perenes de esperanças. Para os grupos empresariais, o fruto da ação de "agitadores", uma ameaça perigosa à paz social. Olhando-as mais de perto percebe-se nelas algumas das características do sindicalismo nacional. Em primeiro lugar, se as compararmos com movimentos grevistas de outros países, no presente e no passado, sua importância, em homens-horas perdidos, duração e amplitude, reduz-se consideravelmente, embora tanto os dirigentes sindicais quanto os industriais concordem - pelo menos publicamente, e por motivos diferentes - em exagerar a importância dessas

${ }^{2}$ É certo que em São Paulo, pelo menos até a I Guerra, havia se formado um proletariado cujas principais lideranças estiveram influenciadas por ideologias de negação do sistema (anarcossindicalista, primeiro, socialista e comunista, depois), e que movimentos grevistas de certa magnitude (como a famosa e sempre citada greve de 1917) chegaram a ocorrer. Tratava-se, no entanto, de um proletariado em grande maioria formado por trabalhadores estrangeiros, cujo âmbito de atuação não ultrapassou os limites das fábricas e da luta por reivindicações as mais elementares. Em nenhum momento chegou a influir na "grande política" ou a obter uma legislação social mais elaborada. 
greves. Os sindicatos brasileiros - mesmo no caso de relativa neutralidade dos poderes públicos - não têm condições de travar longas disputas com os grupos empresariais. As associações sindicais, entre outras deficiências organizatórias, não dispõem de "fundos de greves", razão pela qual dificilmente podem suportar prolongadas paralisações do trabalho. Nas raras vezes em que elas ocorrem, as lideranças são obrigadas a recorrer à solidariedade da população, de eficácia duvidosa ${ }^{3}$. De fato, os movimentos grevistas destinam-se principalmente a exercer pressão sobre o governo e a Justiça do Trabalho que, em última instância, decide qual deve ser a magnitude do reajustamento salarial reivindicado. Dizemos "reajustamento salarial" porque a imensa maioria das greves brasileiras são desencadeadas por motivos econômicos (reajustamento, atraso de pagamento, etc.). As estatísticas sobre movimentos grevistas são extremamente deficientes ou inexistentes entre nós, o que tornam imprecisas as considerações a respeito de movimentos grevistas. Contudo, pode-se aceitar que geralmente têm objetivos econômicos e que são raras as greves que se prolongam depois de uma decisão dos Tribunais do Trabalho. Os movimentos grevistas são frutos de um "clima", dependem de um estado de desespero reinante entre os trabalhadores que deve ser aproveitado pelos ativistas sindicais. Se não encontram "cobertura legal", ou apoio de outros setores políticos, declinam rapidamente por maior que tenha sido a radicalização inicial ${ }^{4}$. O grau de racionalidade das ações grevistas, em comparação com outros países, é muito pequeno. Na maior parte das vezes, a paralisação efetiva do trabalho nas indústrias depende da ação dos piquetes grevistas ${ }^{5}$. Nada há de surpreendente nessas afirmações, se consideramos a inexistência de comissões sindicais de empresa, a baixa taxa de sindicalização e, sobretudo, as motivações assistenciais da minoria de trabalhadores que adere aos sindicatos.

Os sindicatos brasileiros não têm influência significativa no interior das empresas. Não são consultados pelos empresários nem ouvidos quando

\footnotetext{
${ }^{3}$ Caso da greve nas empresas "Perus", de propriedade do grupo Abdalla.

Caso da greve nas empresas "Perus", de propriedade do grupo Abdalla.
${ }^{4}$ Ver nesse sentido a minuciosa descrição das greves de Contagem e Osasco, realizada por Francisco C. WEFFORT, "Participação e Conflito Industrial; Contagem e Osasco" - 1968, São Paulo, Caderno Cebrap n.o 5, 1972.

${ }^{5}$ Ver nossa análise sobre os movimentos grevistas e a ação dos piquetes Leôncio Martins RODRIGUES, Conflito Industrial e Sindicalismo no Brasil, São Paulo, Difusão Européia do Livro, 1966 (II Parte: “Greves Operárias em São Paulo").
}

de modificações técnicas ou de outra natureza no interior das indústrias. $\mathrm{Na}$ ausência de "comissões de fábrica", ou de delegados sindicais, que discutam com a gerência problemas relacionados ao pessoal (dispensa, férias, classificação profissional, etc.), os empresários brasileiros têm sua liberdade de ação limitada apenas pela legislação do trabalho. A prática gerencial é tomar as decisões e esperar, se elas não agradam aos empregados, que suas queixas sejam encaminhadas para a Justiça do Trabalho.

As organizações sindicais que tiveram sua estrutura, modo de funcionamento e funções fixados pela legislação do trabalho - num processo longo que se iniciou em 1930 - não podem apresentar ou apoiar candidatos às eleições em qualquer nível nem participar legitimamente da política nacional. Na realidade, o sindicalismo brasileiro encontra-se em situação de extrema dependência dos poderes públicos - concretamente, do Ministério do Trabalho - para o reconhecimento de novas associações, para a validação das diretorias eleitas, etc.. Cabe ao Ministério do Trabalho a fixação das normas eleitorais nos sindicatos, das condições em que uma greve pode ser decretada e, enfim, de todo o funcionamento interno dos sindicatos $^{6}$. O controle exercido sobre as organizações sindicais pode estreitar-se ou alargar-se de acordo com os interesses governamentais, o que significa dizer que as funções e papéis que o sindicato pode desempenhar dependem, em larga medida, dos grupos que controlam o aparelho estatal e do tipo de orientação política ou econômica que procuram aplicar.

Nos momentos de eleição, tal como vigoravam antes de 1964, não seria preciso dizer que aumentava o campo de barganha das lideranças sindicais. Essas procuravam, então, obter através de compromissos e acordos eleitorais certas reinvindicações que não tinham condições para conquistar por vias conflitivas, através de um confronto direto com o patronato.

\section{A influência do populismo}

Do ponto de vista das orientações políticas e ideológicas dos trabalhadores, observou-se, por outro lado, a persistente predominância do populismo. Estamos entendendo por populismo os movimentos políticos urbanos que mobilizam, geralmente de modo assistemático e desorganizado, diferentes setores das populações pobres em torno de reivindicações que se

${ }^{6}$ Para essa parte, ver especialmente José Albertino RODRIGUES, op. cit. 
situam no plano do consumo, no de melhorias urbanas ou de serviços assistenciais. Não são movimentos que se estruturam em bases "uniclassistas", reunindo grupos sociais homogêneos, unidos por um mesmo modo de vinculação com determinados setores do sistema de produção. Os movimentos populistas, programaticamente, propõem uma melhor participação das camadas baixas na ordem social estabelecida, visando "incorporá-las ao sistema". Apesar disso, a radicalização dos movimentos populistas, a partir de pressões originadas de reivindicações "consumistas" e assistenciais, além de abalar as estruturas estabelecidas de Poder, pode levar a reivindicações alternativas que ponham em questão o modo de organização da produção, o sistema social e político no seu conjunto.

Nas condições brasileiras, os diferentes tipos de movimentos populistas, surgidos no restabelecimento do sistema eleitoral após 1945, formaram-se em torno de líderes das camadas superiores ou médias. Mas não necessariamente, no populismo, as lideranças necessitam sair dessas camadas $^{7}$. A predominância de tais líderes tem decorrido, em larga medida, da incapacidade - que pode ser conjuntural - das camadas populares de criar lideranças próprias, de âmbito nacional. Até agora, quaisquer que tenham sido as diferenças políticas e ideológicas que os separavam, todos os grandes líderes populistas de prestígio nacional saíram das camadas superiores, mais ultimamente, das camadas médias: Getúlio Vargas, Luiz Carlos Prestes, Adhemar de Barros, João Goulart, Miguel Arraes, Jânio Quadros, etc. . .

\footnotetext{
7 Di Tella considera a heteronomia organizatória como um dos componentes dos movimentos populistas. "O populismo pode ser definido como um movimento político que conta com o apoio da classe operária urbana e/ou camponesa mas que não resulta da organização autônoma de nenhum desses dois setores. Ele também é apoiado por setores não operários que mantêm uma ideologia anti-status quo". Torcuato DI TELLA, "Populism and Reform in Latin America" in: Claudio Veliz (ed.), Obstacle to Change in Latin America, Londres, Oxford University Press, 1966 (2 ed.), p. 47. Embora os movimentos populistas tenham tido lideranças originadas de outras classes, tendemos a enfatizar mais seu caráter policlassista do que sua heteronomia uma vez que movimentos de cunho marcadamente operário podem ser dirigidos também por lideranças de classe média ou alta.

${ }_{8}$ Para avaliação mais detalhada das diferenças sócio-profissionais entre os eleitores dos políticos populistas, ver a pesquisa de Francisco C. WEFFORT, "Raízes Sociais do Populismo em São Paulo", Revista Civilização Brasileira, Rio, maio de 1965. Sobre o populismo brasileiro ver, também do mesmo autor, "Estado y Masas en el Brasil", Revista Latinoamericana de Sociologia, Buenos Aires, março de 1965; e Classes Populares e
}

Poder-se-ia analisar com mais segurança as relações entre essas lideranças populistas e a classe operária se dispuséssemos de melhores informações sobre o voto operário. Infelizmente, há pouco estudo a respeito. Os dados e estudos disponíveis indicam que, provavelmente, os eleitores operários dividiam seus votos pelos diferentes candidatos, segundo as opções que lhes eram dadas pelos partidos (ou coligações deles). Há indicações, no entanto, de que nas áreas mais urbanizadas as preferências do proletariado industrial e das classes baixas eram pelos candidatos populistas cujos temas eleitorais iam do paternalismo redistributivista ao moralismo, passando pelo nacionalismo e pelo desenvolvimento ${ }^{9}$. Entre os dirigentes dos principais sindicatos, as preferências eram pelos candidatos que enfatizavam o nacionalismo e o incremento da participação do Estado na economia e na sociedade. Quaisquer que sejam, no entanto, as variações no comportamento eleitoral dos grupos operários e dos dirigentes sindicais, não se delineou, em nenhum momento, uma orientação "classista" do tipo existente nos países de velha industrialização. Mais concretamente, o problema da propriedade privada, que constituiu uma forte motivação para o ativismo das antigas elites operárias, é para todos os fins de adesão dos trabalhadores brasileiros a organizações políticas ou sindicais, praticamente sem significado.

Por outro lado, no plano da participação política, percebe-se que o avanço da industrialização e o consequente aumento numérico do proletariado fabril nem de longe se acompanhou de uma igual ampliação da

Política (Contribuição ao Estudo do Populismo), São Paulo, Faculdade de Filosofia, Ciências e Letras (USP), 1968 (mim.).

${ }^{9}$ Ainda que a distribuição dos votos não obedeça a uma nítida demarcação de classe, alguns estudos sugerem que as camadas baixas tendiam a preferir, para os cargos executivos, os candidatos populistas e que os "partidos conservadores" (UDN e PSD), nas cidades maiores, tinham significativamente menos votos entre os eleitores pobres. Trata-se de uma tendência muito geral porque, por exemplo, Adhemar de Barros, politicamente conservador, recolhia mais votos entre os estratos de baixa escolaridade e nível profissional inferior. Jânio Quadros que, em 1953, nas eleições municipais de São Paulo obteve grande parte de seus votos entre a população pobre, nas eleições presidenciais de 1960, teve forte votação entre as camadas altas. Cf. Gláucio Dillon SOARES, "Classes Sociais e Eleições Presidenciais de 1960", Sociologia, São Paulo, setembro de 1961. Em outro artigo, o autor mostra que os antigos PTB e PSP tendiam a ser, nos centros urbanos, partidos que obtinham seus votos predominantemente entre os estratos baixos, enquanto a UDN se configurava como um partido de classe média. Cf. "Alianças e Coligações Eleitorais", Revista Brasileira de Estudos Políticos, Belo Horizonte, julho de 1964. 
capacidade de intervenção autônoma da classe na política nacional, quer pensemos a questão do prisma da criação de um sindicalismo independente e desvinculado do Estado, ou da formação de um partido de classe.

Poucos operários se apresentam como candidatos nas eleições municipais, estaduais ou federais. Na composição do Congresso brasileiro, particularmente, os trabalhadores não dispõem de nenhuma representação própria. A afirmação não exclui a existência de deputados das camadas médias ou altas que recolhem seus votos preponderantemente entre os trabalhadores e que, nas assembleias estaduais ou na Câmara Federal, se apresentem como porta-vozes dos "trabalhadores", defendendo ou apresentando projetos e leis que respondam a certas reivindicações dos operários ${ }^{10}$.

A constatação da situação acima não implica em afirmar que o processo de industrialização e de urbanização, a ampliação do eleitorado e o aumento numérico das camadas de baixa renda não tivessem alterado significativamente o contexto eleitoral e político, a relação de forças entre os diferentes grupos ${ }^{11}$. Pelo contrário: o aumento do peso eleitoral das camadas baixas mudou o estilo de política "elitista" vigorante na Velha República e criou as condições sociais para a emergência do fenômeno do populismo. A importância política das novas camadas urbanas pobres profissionalmente heterogêneas, politicamente inexperientes e dificilmente controláveis nos centros urbanos pelas velhas técnicas do coronelismo e do chamado "voto de cabresto" - foi percebida bastante cedo por uma nova geração de políticos. Alguns deles, escapando dos velhos esquemas e estilos eleitorais, conheceram um sucesso vertiginoso (e às vezes uma queda rápida) explorando as expectativas dos novos grupos urbanos, entre os quais o proletariado fabril.

\footnotetext{
${ }^{10}$ Ver, para os aspectos relacionados' aos grupos de pressão e as vinculações dos deputados com associações "de classe", a pesquisa de Philippe SCHMITTER, Interest Conflict and Political Change in Brazil, Stanford, Stanford University Press, 1971, especialmente o capítulo: "The Pattern of Interaction: Legislative and Electoral Arenas".

${ }^{11} \mathrm{Na}$ Guanabara, por exemplo, analisando os resultados de vários pleitos, Francisco Pedro de Coutto chama a atenção para o fato de que as chamadas "classes pobres" representam $70 \%$ do total de eleitores, o que torna difícil a eleição de qualquer candidato a um posto executivo sem o apoio de pelo menos uma parte expressiva desse eleitorado. Francisco Pedro de COUTTO, O Voto e o Povo, Rio, Civilização Brasileira, 1966.
}

Ademais, nada do que foi dito implica em negar os conflitos no interior das empresas e mesmo a possibilidade da eclosão de movimentos grevistas de certa envergadura. Não é mesmo de se afastar a hipótese de formas espontâneas de violência operária originadas da situação de trabalho ou de outras situações urbanas. Estas explosões anárquicas são habituais face à inexistência de sindicatos representativos, de negociações sistemáticas entre as empresas e os sindicatos, de comunicações institucionalizadas entre os diferentes níveis do Poder e as camadas operárias (ou suas associações).

As páginas precedentes acentuaram alguns traços do sindicalismo e do proletariado brasileiro que vigoraram até o presente. Cabe indagar, porém, se tenderão a persistir e, em caso negativo, quais as alternativas mais prováveis de mudança. Mais concretamente: as características assinaladas se devem a circunstâncias conjunturais nas quais a conduta das lideranças e o "amadurecimento" político da classe desempenham papel relevante ou decorrem de um contexto estrutural mais amplo, relacionado ao tipo de desenvolvimento industrial e às circunstâncias que presidiram a formação da classe? Quais as possibilidades de emergência de outras modalidades de organização sindical e de outras orientações políticas diferentes das que vigoraram até agora? Em suma: que papéis poderá desempenhar o proletariado industrial na sociedade brasileira? Em que medida poderá ter sua importância aumentada em comparação com outras classes e camadas sociais que até hoje ocuparam as primeiras posições na vida política nacional?

\section{A Estrutura Sindical Brasileira}

Um dos fatos que chama a atenção na história do sindicalismo brasileiro é a extraordinária persistência do tipo de sindicato esboçado após a vitória de Vargas e completado durante o Estado Novo. Atribuiu-se sua criação à influência das doutrinas fascistas então em moda, principalmente à Carta do Trabalho italiana. No entanto, depois de 1945, com a chamada redemocratização do país, o modelo de organização sindical que parecia ter sido uma imposição artificial da ditadura varguista (sob influência fascista) não sofreu alterações que afetassem sua essência. Os sindicatos, sua estrutura, sua legitimidade, seu modo de funcionamento, seus papéis e, em especial, sua subordinação ao Estado, continuaram basicamente aqueles 
estabelecidos durante os anos de Vargas. Visto à distância, parece claro que esse modelo de sindicalismo tem raízes mais profundas na sociedade brasileira e não foi o fruto de uma conjuntura política e institucional excepcional (embora longa).

Naturalmente, houve modificações na atuação dos sindicatos entre 1945 e 1964 e, depois desta última data, até os dias atuais. Após a queda do Estado Novo, na qual novamente os trabalhadores não tiveram participação contra ou a favor, os sindicatos reivindicaram, e conseguiram, o afrouxamento dos laços que os subordinavam muito estreitamente ao Ministério do Trabalho. Obtiveram, principalmente, o direito de greve, formalmente abolido durante os primeiros governos de Vargas. Após 1964, novamente, o controle governamental fez-se mais severo, voltando os sindicatos, por assim dizer, à posição em que estavam durante o Estado Novo. Apesar das mudanças ocorridas, variou apenas o grau e o tipo de dependência ante o Estado, permanecendo os sindicatos - para utilizar uma expressão de J. Albertino Rodrigues - como uma espécie de órgão paraestatal, representante dos trabalhadores ante o poder público e deste ante os trabalhadores. A cobertura dos gastos e despesas dos sindicatos continuou sempre fortemente dependente dos recursos provenientes do então imposto sindical ${ }^{12}$. Além disso, todo o sistema montado para a resolução dos conflitos, especificamente a Consolidação das Leis do Trabalho e a Justiça do Trabalho, não sofreu modificações importantes, a não ser, depois de 1964, a extinção da "lei de estabilidade" e a prerrogativa que o Executivo Federal chamou a si de fixar os reajustamentos salariais, os quais anteriormente eram atribuição dos Tribunais do Trabalho.

Percebe-se, pois, que as mudanças ocorridas depois de 1930 - e que em nossa opinião tenderão a repetir-se - oscilaram sempre no sentido do afrouxamento ou estreitamento do controle governamental sobre os sindicatos, mas jamais se encaminharam para o rompimento dos laços de dependência que amarram as associações operárias ao poder estatal.

${ }^{12}$ Segundo uma pesquisa realizada em São Paulo, o imposto ou a contribuição sindical como é atualmente denominado, representava cerca de $54 \%$ da arrecadação bruta dos sindicatos. Cf. Ophélia RABELLO, A Rede Sindical Paulista, São Paulo, Instituto Cultural do Trabalho, 1965. A porcentagem indicada está provavelmente deflacionada uma vez que decorrem das declarações dos próprios dirigentes sindicais.
É significativo que, mesmo nos momentos politicamente mais favoráveis, as lideranças sindicais não envidassem nenhum esforço sério no sentido da criação de um sindicalismo autônomo. Na realidade, desejaram maior liberdade de ação, maior influência nas decisões políticas através $d a$ aproximação com o Poder, sem pretenderem romper a vinculação estrutural com o aparelho estatal, isto é, sem perderem a "proteção" e a garantia legal de sua representatividade face aos trabalhadores, de um lado, e às empresas, de outro.

Não há dados fidedignos sobre a proporção de operários brasileiros sindicalizados. José Albertino Rodrigues considera que a taxa de sindicalização, em todo o país, por volta de 1960, era aproximadamente de um terço do total dos trabalhadores. Na região sudeste, segundo o mesmo autor, era de $40 \%^{13}$. Ophelia Rabello, baseando-se em informações prestadas pelos próprios sindicatos, estima que a proporção de sindicalizados estaria entre $35 \%$ a $40 \%$ dos assalariados de São Paulo ${ }^{14}$. Segundo os resultados de seu inquérito, aproximadamente $70 \%$ dos sindicatos apresentariam índices de sindicalização inferior à metade dos empregados da indústria. Para Miglioli, $47 \%$ dos empregados na indústria, em 1957, estariam sindicalizados ${ }^{15}$. Para Freitas Marcondes, cerca de um quarto dos órgãos sindicais de São Paulo possuem menos de um terço de trabalhadores do setor ${ }^{16}$. Utilizando outro procedimento (número de trabalhadores que votaram nas eleições sindicais) encontramos $10 \%$ de votantes entre os metalúrgicos, $10 \%$ entre os têxteis (1961), $21 \%$ entre os gráficos e $7 \%$ entre os trabalhadores da indústria química e farmacêutica (1962) ${ }^{17}$.

Quanto ao número total de sindicalizados, Aziz Simão ${ }^{18}$ aponta mais de um milhão já em 1957. Albertino Rodrigues, utilizando dados extraídos do Anuário Estatístico do IBGE, estima em cerca de 1.200 mil o número de aderentes a sindicatos em 1961. Essas cifras, que não se referem apenas a

${ }^{13}$ José Albertino RODRIGUES, op. cit.

${ }^{14}$ Ophélia RABELLO, op. cit.

${ }^{15}$ Jorge MIGLIOLI, Como São Feitas as Greves no Brasil, Rio, Civilização Brasileira, 1963.

${ }^{16}$ Freitas MARCONDES, Radiografia da Liderança Sindical Paulista, São Paulo, Instituto Cultural do Trabalho, 1964.

${ }^{17}$ Leôncio Martins RODRIGUES, Conflito Industrial e Sindicalismo no Brasil.

18 Azis SIMÃO, "Industrialisation et syndicalisme au Brésil", in: Ouvriers et Syndicats d'Amérique Latine (número especial da revista Sociologie du Travail), Paris, n.? 4, 1961. 
operários, mas ao conjunto da população assalariada, são em si mesmas expressivas mas em nossa opinião são fortemente inflacionadas por decorrerem de informações prestadas pelas próprias direções sindicais. Assim, J. Albertino Rodrigues alerta que as cifras geralmente referem-se ao número de associados inscritos (ou que se inscreveram) nos sindicatos e que, a rigor, apenas nominalmente poderiam ser considerados sócios:

Um grande número de trabalhadores procura sua organização sindical no momento em que tem um grave problema a enfrentar, seja de natureza jurídica, seja de natureza assistencial. Não sendo sócio, precisa adquirir essa qualidade para ser atendido ... Resolvido o problema, nem sempre continua a frequentar o sindicato embora nele permaneça inscrito ${ }^{19}$

Deixando de lado o problema da fidedignidade das cifras referentes ao volume de sindicalizados - sobre o que tendemos a concordar com as restrições feitas pelos diferentes autores - cabe indagar se a representatividade das associações operárias pode ser medida apenas em termos numéricos ${ }^{20}$. Diferentes pesquisas com grupos de trabalhadores ${ }^{21}$ mostram, persistentemente, que a grande maioria de sindicalizados adere às suas organizações predominantemente por razões assistenciais (serviços médicos, dentários, etc. e jurídicos). Deste modo, a sindicalização não é suficientemente indicativa de um grau de solidariedade profissional e não significa que o sindicato seja considerado basicamente como um instrumento de pressão e de luta.

É significativo, nesse sentido, que o êxito das greves decorra fundamentalmente da ação dos piquetes. Sem a presença deles os operários

\footnotetext{
${ }^{19}$ José Albertino RODRIGUES, op. cit., p. 140.

${ }^{20}$ Schmitter estima que 16,4\% dos empregados urbanos estavam, em 1940, formalmente inscritos em sindicatos; em 1950, 17,9\%; em 1960, 25,4\%. Mesmo aceitando os critérios utilizados nas estatísticas oficiais, a taxa de sindicalização brasileira é baixa quando comparada com outros países da América Latina. Schmitter considera que, tomando-se como critério de cálculo o total da população, as taxas de sindicalização no Brasil são inferiores às de Cuba, Venezuela, Argentina, Colômbia, Chile, Uruguai, México, Peru, Bolívia e Paraguai. P. SCHMITTER, op. cit., p. 159.

${ }^{21}$ Ver principalmente Juarez R. Brandão LOPES, Sociedade Industrial no Brasil São Paulo, Difusão Européia do Livro, 1964; Leôncio Martins RODRIGUES, Industrialização e Atitudes Operárias; Inaiá Maria Moreira de CARVALHO, "Operário e Sociedade Industrial na Bahia", Estudos Bahianos n. ${ }^{\circ}$, Salvador, Universidade Federal da Bahia, 1971.
}

raramente obedecem a ordem de paralisação do trabalho decretada pelo sindicato. Ora, a maior ou menor liberdade de ação dos piquetes depende da "legalidade" do movimento e da disposição das autoridades em reprimi-lo. O sucesso eventual de uma greve, assim, está em grande parte subordinado à atitude do governo face ao movimento, do apoio ou simpatia que os sindicatos possam encontrar entre os que detêm o poder ou entre outras facções das camadas superiores. A ação sindical necessita considerar esses outros atores e evitar ultrapassar certos limites que levem a uma coalizão geral antioperária das "classes altas".

Em síntese: um balanço da evolução do sindicalismo nos últimos decênios mostra, em comparação com o passado, uma elevação sensível do número de sindicatos e de trabalhadores sindicalizados. Mostra também o aumento da importância dos sindicatos na vida política nacional. Detenhamonos um pouco sobre essas questões. Os trabalhadores industriais constituem hoje um grupo social importante que deve ser tido em consideração por qualquer governo, em situações eleitorais ou fora delas. Numericamente inferiores à massa de trabalhadores agrícolas, ou às populações pobres das grandes cidades, empregadas ou subempregadas no setor terciário, o proletariado industrial localiza-se, no entanto, no setor mais dinâmico da economia. Enquanto consumidor, representa um volume importante de pessoas cujos níveis aquisitivos influem sobre a venda de bens de consumo imediato e mesmo sobre alguns bens de consumo durável. Nos momentos eleitorais, constitui uma massa importante de votos, que deve ser levada em conta. Nesses aspectos, que resultam do simples crescimento numérico dos trabalhadores fabris, a situação parece irreversível.

De outro ponto de vista, no que diz respeito à atuação dos sindicatos, pode-se igualmente afirmar que de 1945 a 1964 de modo geral - apesar de certos períodos de retrocesso - os sindicatos aumentaram sua influência na vida da sociedade brasileira, aumento esse que é parcialmente decorrente do aumento da população operária e do processo de industrialização, ou seja, de transformações socioeconômicas.

Estabelecidos esses pontos, cabe focalizar a questão do ponto de vista político Em relação a outras camadas e grupos sociais, a influência dos sindicatos na política brasileira, no controle ou na participação nas decisões (ao nível municipal, estadual ou nacional), é bastante reduzido. O peso do 
sindicalismo no sistema econômico ou político, sua capacidade de influir sobre as decisões depende essencialmente de sua capacidade de mobilização dos trabalhadores ${ }^{22}$. Até o presente momento, os sindicatos mostraram que só conseguem autonomamente uma mobilização operária de certa envergadura, sem o apoio governamental, quando se trata de reivindicações salariais conduzidas dentro das normas impostas pela legislação do trabalho. O sindicalismo brasileiro, de um modo geral, não dispõe de condições para enfrentar as grandes empresas. Um conjunto de fatores (que tentaremos detalhar mais adiante) lhe é amplamente desfavorável. Daí resulta parcialmente sua vocação "governista", isto é, a necessidade de procurar constantemente a proteção estatal. É a legislação social que legitima os sindicatos, que os transforma obrigatoriamente em representantes dos trabalhadores nas negociações com as empresas. Fundamentalmente, os sindicatos procuram obter por vias políticas, isto é, através de alianças com setores ou facções dominantes, o que não podem conseguir por meio de negociações diretas com o poder econômico. Por isso, estão constantemente à procura de "aliados" nas camadas superiores nos grupos que controlam ou influenciam as decisões do Estado, ou do Legislativo - pois não podem obter, por vias conflitivas, nenhuma reivindicação importante ${ }^{23}$.

Face a um poder estatal hostil, a capacidade de pressão dos sindicatos, especificamente, a de desencadear greves, declina rapidamente. Os dados sobre ocorrência de movimentos grevistas são escassos. Para o Estado de São Paulo, um levantamento feito através de jornais das greves ocorridas entre 1960 e 1964 apresenta o seguinte resultado:

\footnotetext{
${ }^{22}$ A greve, ou a ameaça de a ela recorrer, constitui o instrumento por excelência de pressão de que dispõem os trabalhadores. Entretanto, não é o único. Há outros modos indiretos de pressão, mais desorganizados e relativamente mais espontâneos, capazes de prejudicar a produção, tais como: ausências no trabalho, frenagem, desinteresse, etc. De modo geral, quanto mais sofisticado e caro o equipamento utilizado, maior a necessidade de se ter trabalhadores bem integrados e relativamente "satisfeitos". Daí decorre, em parte, as preocupações pelos "aspectos humanos do trabalho" nas empresas modernas.

${ }^{23}$ Por reivindicação importante estamos entendendo as reivindicações que vão além do simples aumento salarial, tais como: férias remuneradas, aposentadoria, seguro contra desemprego, estabilidade no trabalho, etc.
}

Greves no Estado de São Paulo ${ }^{24}$

\begin{tabular}{|c|c|}
\hline Ano & Número de Greves \\
\hline 1960 & 30 \\
\hline 1961 & 40 \\
\hline 1962 & 68 \\
\hline 1963 & 96 \\
\hline 1964 & 18 \\
\hline
\end{tabular}

Provavelmente, nos algarismos acima, o número de greves está subestimado porquanto os jornais não necessariamente registram todas as paralisações de trabalho e conflitos. Ainda assim percebe-se a queda ocorrida depois de 1964, quando os principais sindicatos do país foram colocados sob intervenção e as antigas lideranças eliminadas. Depois desse ano, praticamente não houve mais greves, com a exceção da de Osasco, que se propagou, se radicalizou e terminou rapidamente. A experiência de outros países demonstra que o movimento sindical não tem condições de desencadear e vencer grandes batalhas insurrecionais contra um poder público bem estabelecido, unificado e hostil. É certo, por outro lado, que mesmo em tais circunstâncias, a classe operária tem sido capaz de fustigar o poder econômico e o poder político com pequenos ou grandes movimentos grevistas. Historicamente, esse processo de conflito resultou na legitimação das organizações sindicais e de suas reivindicações. No caso brasileiro, o que chama atenção foi a facilidade com que os regimes militares estabelecidos depois de 1964 desmontaram o anterior "esquema sindical" e conseguiram impedir, apesar da compressão salarial, a eclosão de qualquer conflito importante. Provavelmente, não há um só país de nível de industrialização equiparável ao brasileiro em que o movimento operário e sindical seja tão fraco.

O estudo do sindicalismo nacional nos primeiros anos da década de 1960 acrescenta novos elementos para a avaliação do tipo de orientação predominante entre as lideranças sindicais e dos instrumentos de pressão de que dispõem para participar da "grande política". O período que começa em 1960 e termina em 1964 representa os anos de grande atividade sindical, em que o movimento operário brasileiro experimentou o desencadeamento de

${ }^{24}$ Cf. Cassiano Marcondes RANGEL FILHO e Maria Hermínia B. Tavares de ALMEIDA, Nacionalismo e Greve, São Paulo (dat.). 
greves de caráter nacional e de fundo político. Cinco "greves políticas" podem ser registradas: a) agosto de 1961, quando da renúncia de Jânio Quadros; b) dezembro de 1961, no Recife, em favor da Sudene; c) janeiro de 1962, na Petrobrás, em prol de uma "diretoria nacionalista"; d) julho de 1962, greve nacional de 24 horas (o objetivo principal dessa greve foi a recusa da Câmara Federal em apoiar Santhiago Dantas para Primeiro Ministro. Os sindicatos - representados especialmente pela CNTI, PUA, Sindicatos de Aeroviários, Operários Navais, Federação dos Trabalhadores em Indústrias Gráficas, Condutores de Veículos Rodoviários, etc. apresentavam, ademais, outras reivindicações tais como a formação de um "governo nacionalista e democrático", "reformas de base", medidas contra a carestia, etc.); e) Greve de setembro de 1962, reclamando especialmente a realização do plebiscito relativo à extinção do "regime parlamentar".

A simples verificação dos objetivos dessas greves indica que os sindicatos deveriam contar com o apoio ou simpatia de outros setores políticos "extrassindicais". Detenhamo-nos um pouco mais sobre as "greves gerais" de julho e setembro de 1962. As finalidades do movimento grevista coincidiam com os propósitos da Presidência da República: o fim do regime parlamentarista. A primeira greve geral dura 24 horas; a segunda é desencadeada numa sexta-feira ( 14 de setembro) e suspensa no domingo ... Uma apreciação dos setores econômicos afetados mostra que a paralisação do trabalho atingiu basicamente as empresas estatais ou paraestatais: Petrobrás, transportes urbanos, portos, Rede Rodoviária Nacional, etc.. Nas empresas privadas não houve greve. Em outras palavras, isso significa que a adesão dos trabalhadores aos movimentos grevistas só ocorreu nas empresas em que, provavelmente, os trabalhadores contavam que não haveria represálias por parte da administração nem mesmo desconto no salário. Por outro lado, é possível que nesses setores, de empresas estatais ou paraestatais, os sindicatos tenham conseguido maior penetração e influência entre os trabalhadores, face à posição mais tolerante da direção das empresas, ao contrário do que sucedia no setor privado.

Seria superficial concluir que parte do movimento sindical, especificamente os novos organismos da cúpula, como o PUA, a CGT, o Forum Sindical de Debates, etc., serviram como grupos de pressão em benefício de interesses políticos de outras facções das classes superiores ${ }^{25}$ Entretanto, essa constatação, evidente quando se examinam os motivos da greve, não explica por que as direções sindicais, no período considerado, optaram por essa via. Percebe-se, ao examinar-se as "reivindicações secundárias" que justificaram o desencadeamento do movimento, que as lideranças sindicais, aliando-se a outras facções, dando "base de massa" ao governo, procuravam outras vantagens para os trabalhadores que só conseguiriam mediante a sua incorporação numa coalizão "nacionalistapopulista" mais ampla que facilitasse a mobilização da classe ${ }^{26}$.

A alternativa seria uma política autônoma (e conflitiva) voltada para o fortalecimento das organizações sindicais, com a tentativa de incorporar largas parcelas das camadas trabalhadoras às associações operárias, de fortalecimento da coesão interna da classe, em oposição ao governo e às empresas. Essa via, que uma visão militante do sindicalismo e do proletariado tende a valorizar, tem seu preço e, no fundo, não decorre de uma opção livremente oferecida aos militantes e dirigentes sindicais. Como acentua E. Faletto,

.... a natureza do sindicalismo está sempre em estreita relação com o sistema social em que se insere ... A incorporação dos setores operários não depende tão somente da existência de uma 'vontade de participação'; sua possibilidade, a natureza que venha a adquirir, caso

\footnotetext{
${ }^{25}$ Agindo no sentido dos interesses imediatos da Presidência da República, os sindicatos aproveitaram para incluir outras reivindicações, de caráter mais geral, tais como: independência econômica e política; alteração da estrutura agrária; democratização do Poder e ampliação das liberdades sindicais e democráticas; aumento da participação do Estado na economia; defesa do nível de vida das camadas populares (Cf. Cassiano RANGEL FILHO e Maria Hermínia T. de ALMEIDA, op. cit.). Claro está que o atendimento de tais reivindicações suporia transformações sociais mais profundas. Note-se, contudo, que após a greve de julho de 1962 (indicação de um Primeiro-Ministro que apoiasse as "reformas de base"), os sindicatos obtiveram o $13^{\circ}$ salário.

${ }^{26}$ Certamente os aspectos ideológicos desempenharam, no período considerado, um papel relevante na aproximação das lideranças sindicais com o governo. Em alguns casos, tudo indica que houve preponderantemente um esforço das lideranças nacionalistas de promover e facilitar a mobilização dos trabalhadores e de ampliar a participação dos sindicatos no aparelho governamental. Ver especialmente Keneth Paul ERICKSON, Labor in the Polical Process in Brazil 1970 (Tese de doutorado apresentada no Departamento de Ciências Políticas da Universidade de Columbia, Nova York). O capítulo V, "The Labor Ministery Under Almino Afonso:a Case Study in Political Change", é particularmente importante.
} 
isso ocorra, depende das características da situação social e das transformações que possam ser realizadas na estrutura do $\operatorname{poder}^{27}$.

No caso brasileiro, a opção por uma linha independente pressuporia o conflito com as empresas e o Estado. Essa alternativa não depende apenas de uma vontade das lideranças. Estas refletem sempre, de alguma maneira, as características da classe operária: seu grau de coesão, o tipo de aspiração predominante na massa, sua situação em relação a outros grupos e camadas sociais, etc.

As ideologias nacionalistas ou populistas, o esforço das lideranças sindicais de se integrarem num movimento social mais amplo e de estabelecerem vinculações com outras forças políticas e grupos sociais não decorrem apenas da fraqueza do sindicalismo, reflexo em última instância, da fraqueza da classe operária no Brasil. O tipo de orientação populistanacionalista advém igualmente da natureza dos problemas que afetam aos trabalhadores nos países subdesenvolvidos e do papel desempenhado pelo Estado na promoção do desenvolvimento econômico. Nos países da velha industrialização, as condições sociais, econômicas, políticas e culturais requeridas para a formação das sociedades modernas criaram-se mais lentamente, em função geralmente da própria evolução e expansão da indústria. Em outras palavras, a modernização resultou basicamente da expansão econômica, o que equivale dizer, da ação da burguesia enquanto classe. Os aspectos relacionados à situação fabril, à defesa do status profissional, etc., foram sobressalentes para os trabalhadores e constituíram o ponto central da ação sindical. Nas nações de industrialização recente, um conjunto de problemas que afetam a situação do operário, enquanto consumidor pobre e morador de áreas urbanas, sobrepõem-se aos aspectos sócio-profissionais do trabalho e não encontram solução no âmbito das relações industriais. Dependem, numa escala desconhecida nos países de industrialização liberal, da política do governo e de sua atitude face às demandas dos grupos assalariados. Em qualquer país, as posições assumidas pelo Estado ante as exigências operárias é fator importante para a estratégia sindical. Nas condições brasileiras, é fator decisivo.

${ }^{27}$ Cf. Enzo FALETTO, "Industrialização e Classe Operária na América Latina" in: Leôncio Martins Rodrigues (org.), Sindicalismo e Sociedade, pp. 336-7.

\section{A legislação do trabalho e a classe operária}

Os efeitos da legislação do trabalho sobre as atitudes do proletariado brasileiro ainda não estão bem esclarecidos, assim como os motivos que levaram à sua promulgação. De um lado, pode-se aventar a hipótese de que a falta de agressividade reivindicatória dos trabalhadores seria decorrência da concessão, pelo governo surgido com a vitória da Aliança 'Liberal, de uma legislação social "avançada para a sua época". Subjacente a esta hipótese, está a ideia de que, sem a intervenção do Estado na área sindical e industrial, os trabalhadores seriam compelidos a se organizar autonomamente, a criar sindicatos mais sólidos e representativos de onde emergiriam "líderes autênticos". De outro lado, afirma-se que a legislação social nada mais fez do que ceder a uma pressão operária preexistente.

A história do movimento sindical brasileiro não oferece muitas evidências favoráveis a essa última hipótese, embora não haja muitos elementos que possibilitem rejeitá-la categoricamente, uma vez que vários aspectos relativos ao período em questão requerem uma investigação histórica mais detalhada. Os dados disponíveis sugerem, no entanto que, antes de 1930, apesar do aumento do número de associações operárias, o movimento operário teria escassa possibilidade de obter, por si mesmo, vantagens equivalentes às outorgadas pela legislação do trabalho. Azis Simão registrou um total de 108 greves ocorridas em todo o Estado de São Paulo no período compreendido entre 1901 e 1914; para os anos que antecederam o início da intervenção estatal na "questão social" (1915-1929), o mesmo autor anotou 107 greves. A. Simão assinala que

... em 1919, ainda ocorreu uma greve generalizada, seguida de uma série de outras, setoriais e interprofissionais de expressivas amplitudes. Em 1920, verificou-se uma única greve interprofissional. Daí a 1937, não se registraram senão conflitos de trabalhos limitados a estabelecimentos ou setores econômicos. E a partir de 1923, decresceu até mesmo o número de ocorrências circunscritas a categorias profissionais e empresas, sendo que houve anos sem nenhum registro na Capital ou no interior ${ }^{28}$.

Ademais, a década de 1930, quando se ampliou a intervenção estatal no terreno trabalhista, coincide, em São Paulo, com o incremento das

${ }^{28}$ Azis SIMÃO, Sindicato e Estado, p. 108. 
migrações internas para o Estado e para a Capital, aumentando a disponibilidade de mão de obra e pondo à disposição dos empregadores uma massa de trabalhadores inteiramente desprovida de experiência política e sindical. Muito provavelmente, como também acontece nos casos de crise econômica e desemprego, a capacidade de pressão dos trabalhadores diminuiu $^{29}$. Não há dados que sugiram, no período considerado, um aumento da influência política e sindical dos trabalhadores que tivesse sido quebrada, subitamente, pela ação regulamentadora do Estado. A hipótese mais provável, é que a intervenção e o controle dos sindicatos, que se inicia na década de 1930, deu-se num momento de refluxo do movimento sindical ${ }^{30}$

Nada indica que, com a possível exceção dos grupos de trabalhadores qualificados, a massa operária estivesse em condições de obter, através de um processo de enfrentamento direto com os empregadores, um conjunto importante de vantagens profissionais e sociais. Parece-nos, pois, que a intervenção estatal garantiu, para os grupos de trabalhadores urbanos de baixa qualificação, mais benefícios sociais do que os sindicatos teriam podido consolidar. As vantagens foram essencialmente de natureza social: férias, aposentadoria, descanso semanal remunerado, regulamentação da jornada de trabalho, pagamento de horas-extras, etc. Do ponto de vista estritamente salarial, a intervenção estatal deve ter tido influência bastante reduzida, pois a decretação do primeiro salário mínimo, que interessa à

${ }^{29}$ W. Dean, na sua excelente monografia sobre a industrialização paulista, afirma que a "força dos sindicatos e, portanto, sua capacidade de negociar independentemente da intervenção governamental, crescera muito desde a I Guerra Mundial” (p. 174). Há, ao nosso ver, uma superestimação do poder dos sindicatos. O mesmo autor assinala mais adiante, referindo-se à crise econômica de 1930, que o desemprego aumentara e que muitas indústrias operavam muito abaixo de sua capacidade, fato que, como salientamos, normalmente coloca a classe operária em posição desvantajosa para a negociação (ver o cap. "Os Industriais e o Estado Liberal”). Warren DEAN, A Industrialização de São Paulo, São Paulo, Difusão Européia do Livro, 1971.

${ }^{30}$ De fato, o fenômeno não foi apenas brasileiro. A segunda metade da década de 1920 foi mareada pelo recuo mundial da classe operária. Esta havia começado já antes de 1918 a se recompor do abalo produzido em suas fileiras pela eclosão da I Guerra. O armistício deu-se num momento de debilitamento das economias e do sistema de poder das principais nações capitalistas e da vaga ascendente do movimento operário, estimulado pela Revolução Russa. Porém, na década seguinte, depois do malogro dos levantes da Alemanha, da Hungria, da derrota da greve geral inglesa, etc., o movimento político e sindical operário, dilacerado por cisões internas, refluiu novamente. imensa maioria dos trabalhadores braçais, só veio a ocorrer muitos anos mais tarde, durante a II Guerra. É certo, no entanto, que as vantagens outorgadas representaram uma elevação indireta dos salários e, para o empregador, um aumento do custo da mão de obra, estimulando a racionalização da produção e o emprego de equipamento.

A história do movimento sindical em outros países mostra que são os grupos de trabalhadores qualificados, com forte solidariedade profissional e "tradição operária", os mais capazes de constituir associações com condições de enfrentar um patronato poderoso e obter vantagens sociais de maior amplitude. Trabalhadores de baixa qualificação geralmente tendem a procurar, por meios legislativos e ou políticos, certos benefícios que não podem conseguir através da barganha direta com os empregadores. Nos EUA, a sindicalização dos trabalhadores não qualificados das grandes indústrias e a expansão do CIO foi facilitada pelas novas leis que favoreceram as organizações sindicais durante o New Deal. Em outros países do Terceiro Mundo, com forte excesso de mão de obra de baixa qualificação, o conjunto da classe operária só conseguiu certas vantagens sociais quando da ascensão ao poder de elites modernizantes e nacionalistas.

O estudo de Juarez B. Lopes, sobre a formação do sindicato em duas comunidades do interior de Minas, mostra como na presença de um patronato forte que dominava o sistema político local, com relações de trabalho predominantemente paternalistas e grande disponibilidade de mão de obra, a formação do sindicato e a aplicação do salário mínimo foi facilitada pela existência da legislação do trabalho e pela intervenção do Ministério do Trabalho. As lideranças operárias locais apoiaram-se nas exigências legais e nas garantias oferecidas pelo Ministério do Trabalho para organizarem localmente o sindicato dos têxteis ${ }^{31}$.

Considera-se, às vezes, que a intervenção do Estado seria responsável pelo declínio do revolucionarismo proletário existente no passado. A observação da evolução do sindicalismo em outros países leva a encarar com ceticismo essa tese. $\mathrm{O}$ declínio das concepções revolucionárias foi um fenômeno geral no interior do sindicalismo depois que certas conquistas foram obtidas e as organizações sindicais legitimadas. A formação de

31 Juarez R. Brandão LOPES, Crise do Brasil Arcaico, São Paulo, Difusão Européia do Livro, 1971. 
"burocracias sindicais", que no Brasil se deveu à intervenção estatal, é igualmente um fenômeno que se encontra em toda parte, quando os sindicatos se transformaram em organizações de massa e desapareceu o antigo sindicalismo de elites operárias.

Além disso, quando se atenta para o número de sindicatos formados e de trabalhadores que aderiram aos sindicatos nos diferentes períodos, percebe-se que a legislação trabalhista facilitou a adesão dos operários (e demais setores assalariados) às novas associações. $\mathrm{O}$ aumento do número de sindicatos e de operários sindicalizados, depois de 1930, foi de tal magnitude que não pode ser atribuído ao simples crescimento do proletariado industrial.

Seria ocioso afirmar que a legitimação dos sindicatos e a extensão das vantagens trabalhistas se acompanhou do controle das associações operárias e eliminação das que não se enquadraram nas exigências legais.

Do ponto de vista dos efeitos da legislação do trabalho sobre as orientações da classe, especificamente de sua capacidade de pressão e barganha, parece não haver dúvida que os novos dispositivos contribuíram, em escala difícil de ser medida, para a eliminação de alguns pontos de atrito entre empregados e empregadores, ou melhor, os transferiram para a esfera legal. Mas novamente volta a pergunta: em que medida a fraca coesão grupal dos trabalhadores e sua baixa agressividade reivindicatória é uma resultante do paternalismo estatal? Por que os trabalhadores, principalmente depois de 1945, não procuraram romper a camisa de força que tolhia a autonomia sindical? Por que não procuraram tornar-se independentes do Ministério do Trabalho?

Nossa hipótese é que certas características do sindicalismo (e da classe operária) no Brasil, especificamente sua limitada capacidade de atuação autônoma e de pressão, não resultaram principalmente da outorga da legislação do trabalho e da vinculação das instituições sindicais ao aparelho do Estado, mas de outras variáveis socioeconômicas, culturais e políticas relacionadas ao processo de formação do proletariado, à sua posição na sociedade em confronto com as demais classes e forças políticas. A intervenção do Estado, em razão do momento histórico em que ocorreu, foi, como era natural, interpretada em função das doutrinas corporativistas e fascistas. A "inspiração italiana” parece evidente quando se cotejam certos trechos da "Carta del Lavoro" com as concepções corporativistas brasileiras, teorizadas por Oliveira Vianna ${ }^{32}$.

A evolução posterior da sociedade brasileira, a coexistência da estrutura sindical "corporativa" com as instituições da democracia representativa após a redemocratização de 1945, sua manutenção na reação antipopulista iniciada em 1964, sugerem que a reordenação da estrutura sindical e sua vinculação com o aparelho estatal, começada em 1930 não resultaram de fatores políticos circunstanciais, mas respondem a modificações mais profundas na sociedade brasileira. Fator essencial foi a modificação das funções preenchidas pelo Estado após o esboroamento do esquema oligárquico de poder. A partir de então, o Estado passou a assumir maiores responsabilidades na promoção da expansão econômica e modernização da sociedade brasileira e, nesse passo, chamou a si a regulamentação do relacionamento das classes sociais entre si. Não se trata aqui de que o Estado - apesar de seus aspectos bonapartistas - esteja acima das classes e de seus conflitos. A política governamental reflete, de algum modo, mudanças estruturais na sociedade brasileira, como por exemplo, a ascensão da burguesia nacional, o aumento da importância das camadas médias, dos setores populares e operários, etc.. Porém, os grupos e camadas emergentes, na medida em que são relativamente pouco coesos, segmentados e limitados a algumas áreas do país, isto é, na medida em que no existem nacionalmente, procuram agir principalmente através do Estado, quer se trate dos cafeicultores, dos usineiros, dos industriais, dos grupos de classe média, do capital estrangeiro ou dos assalariados e proletários urbanos. Obviamente, a influência dos diferentes grupos e classes sociais sobre a política governamental, assim como o tipo e meios de pressão de que dispõem, variam de acordo com a sua natureza social específica e com as transformações sociais e econômicas do país. Porém, o Estado continua sendo o instrumento básico a ser utilizado por cada grupo para a defesa dos seus interesses. À fraqueza do proletariado industrial corresponde, noutra dimensão, a fraqueza da burguesia industrial e, de um modo geral, das demais "classes econômicas", tais como os fazendeiros, os trabalhadores agrícolas, etc., o que confere a certas instituições, como o Estado, as Forças

${ }^{32}$ Ver Oliveira VIANNA: Problemas do Direito Corporativo, São Paulo, José Olympio, 1938. Problemas do Direito Sindical, Rio, Editora Max Limonad, 1943, e Direito do Trabalho e Democracia Social, São Paulo, José Olympio, 1951. 
Armadas, a Igreja, e a certas categorias sociais, como os militares, os tecnocratas, os intelectuais, um papel sobressalente na política e no desenvolvimento econômico brasileiro.

Trata-se de uma situação que tem raízes na própria formação histórica da sociedade nacional e na natureza do processo de industrialização. Ao contrário dos países de desenvolvimento capitalista "clássico" e de tradição liberal, a "sociedade civil" como atualmente está em voga denominar, é fraca perante o Poder do Estado ${ }^{33}$. Assim, a constante procura de apoio nas estruturas do Poder estatal por parte das direções sindicais não decorre de sua vocação conciliadora inata, mas das escassas chances de êxito de um tipo de ação baseada no conflito aberto com o Poder político e econômico sem o apoio de outros setores e forças sociais.

\section{Os Trabalhadores Brasileiros: Expectativas e Atitudes}

Antes de passarmos à análise das expectativas e tipos de orientação predominantes entre os trabalhadores industriais, conviria destacar algumas características mais gerais da classe operária no Brasil.

Com exceção de São Paulo e do Rio de Janeiro onde, desde o início do século, constituíram-se alguns núcleos industriais, pode-se dizer que o proletariado fabril brasileiro é de formação bastante recente, contando no seu meio forte proporção de trabalhadores de origem agrícola. Não se dispõe de estatísticas nacionais que possibilitem averiguar com precisão o meio social de origem do atual proletariado. As pesquisas realizadas com grupos de operários (de caráter monográfico) sugerem que a proporção de trabalhadores originários de famílias operárias é pequena. Ao que tudo 110 indica, parte importante da força de trabalho recrutada nos últimos decênios veio do setor rural ou do setor terciário ${ }^{34}$.

A proporção de trabalhadores recrutados da agricultura varia segundo a região e o ramo industrial. Ao que parece, a indústria paulista abriga uma proporção de trabalhadores de origem rural mais elevada do que em outras partes uma vez que seu parque fabril atraiu trabalhadores de todos os Estados e regiões agrícolas. Talvez São Paulo seja uma das poucas cidades do Brasil cujo crescimento urbano foi determinado basicamente pela expansão industrial. Em outras cidades, como o Rio de Janeiro, é possível que a proporção de operários originários da agricultura seja menor. Pelo que sugere uma pesquisa realizada na Bahia, a proporção de trabalhadores vindos da agricultura não é tão elevada nesse Estado. Nossa hipótese seria de que, nas cidades onde o crescimento urbano precedeu a instalação de indústrias, como no caso de Salvador, o patronato local disporia de uma força de trabalho urbana empregada ou subempregada no setor terciário ${ }^{35}$, ao contrário do que ocorreria em São Paulo. Não seria possível, na ausência de pesquisas de maior âmbito, determinar com precisão a porcentagem de trabalhadores de origem rural na indústria brasileira no seu conjunto. Os dados fragmentários disponíveis indicam situações variadas. A pesquisa de Juarez Brandão Lopes (dados coletados em 1958) revela forte proporção de trabalhadores com experiência pretérita de trabalho na agricultura ${ }^{36}$. Outra pesquisa mais recente, de Andréia Loyola, ainda no Estado de Minas (Juiz de Fora), encontrou $37 \%$ de trabalhadores nascidos no meio rural ${ }^{37}$. É possível que em algumas cidades pequenas, em razão do paternalismo mais fortemente estabelecido, o patronato local se incline a recrutar seus novos operários nas famílias de trabalhadores já empregados em seus estabelecimentos (caso das

\footnotetext{
${ }^{34} \mathrm{Na}$ pesquisa que realizamos numa indústria automobilística, a proporção de trabalhadores semiqualificados que tinha trabalhado na agricultura era de 53\%. Leôncio Martins RODRIGUES, Industrialização e Atitudes Operárias.

35 Estudo, sobre o operariado industrial baiano, indica que $62 \%$ dos trabalhadores entrevistados $(\mathrm{n}=840)$ se declararam de origem urbana, embora a porcentagem variasse bastante segundo a cidade. Operário Industrial na Bahia, Salvador, Secretaria do Trabalho e Bem Estar Social. (Dados coletados em 1967).

${ }^{36}$ Juarez R. Brandão LOPES, Crise do Brasil Arcaico, São Paulo, Difusão Européia do Livro, 1967.

${ }^{37}$ Andréia Loyola, O Trabalhador Têxtil: Atitudes e Expectativas (Um Estudo de Caso em Minas Gerais). 1972 (dat.).
} 
fábricas estudadas no interior de Minas). Assim sendo, a porcentagem de operários provenientes do "meio urbano" passa a ser mais elevada do que nas Capitais, especialmente São Paulo ${ }^{38}$. Cumpre ver, ademais, que o grosso da corrente migratória se realiza do campo para as grandes cidades e não para as pequenas cujas possibilidades de emprego são escassas.

Embora não se possa estimar as dimensões da força de trabalho fabril oriunda da agricultura, pode-se aceitar que ela é elevada e que ainda mais elevada é a proporção de trabalhadores que, embora não tenham pessoalmente trabalhado na lavoura, vêm de famílias camponesas ou de assalariados agrícolas.

Esse fato tem levado alguns sociólogos a falar na persistência de modos de sentir, pensar e agir de tipo tradicional. Os laços de solidariedade que uniriam os operários seriam de tipo primário, dificultando sua adesão a ações coletivas baseadas numa solidariedade profissional ou de classe, de tipo secundário. Além disso, os trabalhadores tenderiam a ver nos sindicatos uma instituição de prestação de serviços jurídicos e médicos, transferindo para a cidade expectativas elaboradas no meio rural ${ }^{39}$.

Do ponto de vista da orientação social da classe, as pesquisas realizadas evidenciam que os trabalhadores estão movidos por aspirações de ascensão social ("conduta de mobilidade", no sentido definido por Touraine $^{40}$. A entrada no meio fabril não seria percebida como um rebaixamento na escala social. Não necessariamente esses trabalhadores integrar-se-iam facilmente à indústria, adaptar-se-iam sem problemas ao trabalho, à hierarquia da fábrica, às normas disciplinares, ao sistema de autoridade, etc.. Os operários recém-ingressados ao sistema industrial valorizariam principalmente os aspectos externos desse último, isto é, não tanto o trabalho mas o emprego fabril (salários mais elevados, férias, aposentadorias e outras vantagens). Esse tipo de participação no sistema industrial não seria favorável para a emergência de formas coletivas de

${ }^{38}$ A expressão "meio urbano" deve ser tomada com reserva. Em se tratando de pequenas cidades, as atitudes e valores dominantes e o padrão de relações industriais podem ser marcadamente tradicionais.

${ }^{39}$ Juarez R. Brandão LOPES, Sociedade Industrial no Brasil, Cap. II: "O Ajustamento do Trabalhador à Indústria: Mobilidade Social e Motivação".

${ }^{40}$ A. TOURAINE e O. RAGAZZI, Ouvriers d'Origine Agricole. ação, para a solidariedade grupai e para a adesão às associações operárias. Pelo contrário: incentivaria as aspirações de evasão da "condição operária" e o desejo de se estabelecer por conta própria. O sentido da mobilidade desses grupos dar-se-ia mais em direção ao meio urbano do que ao meio industrial, sendo o emprego fabril entendido principalmente como um momento passageiro da vida do trabalhador ${ }^{41}$.

A influência dos valores tradicionais passou a ser notada após o estudo pioneiro e importante de Juarez B. Lopes sobre trabalhadores de origem rural em São $\mathrm{Paulo}^{42}$. Nossas pesquisas numa indústria automobilística sugerem, no entanto, que a conduta de mobilidade é mais geral, no sentido de ser encontrada igualmente entre trabalhadores de origem urbana ${ }^{43}$. A pesquisa de Luiz Pereira ${ }^{44}$, assim como a de Inaiá Carvalho ${ }^{45}$ dão indicações no mesmo sentido. Os estudos efetuados com grupos operários sugerem que as aspirações de evasão, de estabelecimento por conta própria, não parecem tão vinculadas à origem rural da mão de obra, mas um traço comum da orientação dos trabalhadores fabris.

Porém, ainda que os novos operários não se integrem facilmente ao meio social da indústria, economicamente esta constitui um forte atrativo em virtude dos salários mais elevados e de outras vantagens que oferece a trabalhadores provenientes de regiões escassamente industrializadas. $\mathrm{Na}$ verdade, e de modo mais amplo, não só o trabalho fabril stricto sensu mas também os "bolsões" industrializados e modernizados, os grandes centros urbanos, a inserção no mercado de trabalho capitalista significam uma ascensão social para os trabalhadores das áreas atrasadas economicamente.

As pesquisas efetuadas com operários industriais e outros extratos populares vêm indicando que a maior parte dos entrevistados considera que

\footnotetext{
${ }^{41}$ Essa hipótese, levantada inicialmente por A. Touraine ("Industrialisation et Conscience Ouvrière à São Paulo" in: Ouvriers et Syndicats d'Amérique Latine, número especial da Sociologie du Travail) vem sendo corroborada por posteriores estudos. Veja-se, a propósito, a pesquisa de Inaiá Maria M. de CARVALHO, op. cit.

${ }_{42}$ Juarez R. Brandão LOPES, Sociedade Industrial no Brasil.

${ }^{43}$ Leôncio Martins RODRIGUES, Industrialização e Atitudes Operárias.

${ }^{44}$ Luiz PEREIRA, Trabalho e Desenvolvimento no Brasil, São Paulo, Difusão Européia do Livro, 1965.

${ }^{45}$ Inaiá Maria de CARVALHO, op. cit.
} 
sua situação econômica vem melhorando ${ }^{46}$. Face à extrema concentração da renda no Brasil, ao fato de que parcela considerável de trabalhadores industriais tem rendimento pouco mais elevado do que o salário mínimo ${ }^{47}$, as opiniões "otimistas" só encontram explicação quando se considera a situação pretérita de pobreza dos entrevistados no meio urbano e principalmente no meio rural. A hipótese, no caso, seria de que, embora a pirâmide da distribuição da renda não se tenha modificado substancialmente no transcorrer do avanço da industrialização, a maior parte dos grupos urbanos, inclusive os trabalhadores manuais, experimentou alguma melhora durante o processo de desenvolvimento: os trabalhadores de origem agrícola, ao se inserirem no mercado de trabalho urbano, passando a receber pelo menos o salário mínimo e a gozarem dos benefícios assegurados pela legislação ${ }^{48}$; os trabalhadores de origem operária, mais qualificados, ao ascenderem nas próprias empresas ou se estabelecerem por conta própria. Nestas condições, os trabalhadores manuais e os grupos de baixa renda teriam melhorado sua situação e elevado seu padrão de vida no decorrer do processo de desenvolvimento, principalmente mediante benefícios

46 Em nossa pesquisa com os trabalhadores da indústria automobilística, apenas uma pequena parcela dos respondentes declarou que sua situação tinha piorado economicamente. No caso, tratava-se de operários de uma indústria moderna, cuja média de salários era bem mais elevada do que a vigorante no parque industrial paulista. Contudo, pesquisa mais recente, abrangendo a população de 14 favelas do Rio e seis de São Vicente (Estado de São Paulo) indica que 68\% (contra apenas 32\%) dos entrevistados declararam que sua situação tinha melhorado. (A coleta do material é do segundo semestre de 1969). Cf. Carlos Estevan MARTINS, "Integración Social y Mobilización Política en la Clase Baja Urbana del Brasil", Revista Latinoamericana de Ciência Política, Santiago, FLACSO, abril de 1971. O autor conclui que "como essa avaliação (dos entrevistados) apenas parcialmente se baseia em avanço efetivamente obtido dentro do sistema interno de estratificação, os resultados marginais parecem sugerir que a experiência de mobilidade reportada pelos favelados deve ter origem em grupos de referência situados fora do contexto urbano, e que servem de base para as comparações a partir das quais os favelados experimentam um sentimento de satisfação relativa com o ocorrido nos últimos cinco anos” (p. 61).

47 Assinala Francisco Oliveira que "até 1967, 36,3\% do total de empregados urbanos registrados no Brasil, estavam incluídos na faixa de remuneração de um salário-mínimo... essa porcentagem variava de um mínimo de $28 \%$ para o Rio Grande do Sul, passando por São Paulo com 30,6\% ate Minas Gerais com o máximo de 50,5\%; 67,5\% dos que recebiam salário-mínimo eram trabalhadores industriais". Francisco OLIVEIRA, A Economia Brasileira: Notas para uma Revisão Teórica, São Paulo, Cebrap, 1972 (mim.).

${ }^{48}$ Inaiá Maria de Carvalho assinala que, na Bahia, o "simples cumprimento da lei aparece (para o operário) como fator positivo para a imagem da direção (da empresa)". Op. cit., p. 54 assistenciais e novas oportunidades profissionais, apesar de que a distribuição da renda não se tenha tornado mais igualitária e de que os salários reais, para o conjunto dos trabalhadores manuais e assalariados pobres, tenham aumentado pouco.

Os dados da tabela abaixo são suficientemente ilustrativos. Cinco por cento da população apropriam-se de mais de um terço da renda total. Foi também o grupo que, no decênio em questão, mais aumentou sua participação. Observa P. Singer que a classe E, cuja maioria de seus membros vive no campo, pode ser considerada como "fora da economia de mercado, pelo menos como parcela significativa da demanda efetiva. Quanto à classe D, que corresponde às massas urbanas de baixa renda, sua participação na renda total, deteriorou-se menos, sendo a sua queda principal o resultado do "arrocho salarial" 49 .

Distribuição da renda no Brasil - 1960-1970

\begin{tabular}{|l|c|c|c|c|c|}
\hline \multirow{2}{*}{$\begin{array}{l}\text { Classe } \\
(1)^{*}\end{array}$} & $\begin{array}{c}\text { \% da } \\
\text { Renda } \\
\text { Total }\end{array}$ & $\begin{array}{c}\text { Renda per } \\
\text { capita } \\
(3)^{*}\end{array}$ & $\begin{array}{c}\text { \% da } \\
\text { Renda } \\
\text { Total }(3)^{*}\end{array}$ & $\begin{array}{c}\text { Renda per } \\
\text { capita(3)* }\end{array}$ & $\begin{array}{c}\text { Aumento em\% } \\
\text { da renda per } \\
\text { capita }\end{array}$ \\
\hline $\mathrm{A}$ & 11,7 & 8.350 & 17,8 & 17.700 & 112,0 \\
\hline $\mathrm{B}$ & 15,6 & 2,780 & 18,5 & 4.590 & 65,0 \\
\hline $\mathrm{C}$ & 27,2 & 1.295 & 26,9 & 1.780 & 37,5 \\
\hline $\mathrm{D}$ & 27,8 & 662 & 23,1 & 768 & 16,0 \\
\hline $\mathrm{E}$ & 17,7 & 253 & 13,7 & 272 & 7,5 \\
\hline SOMA & 100,0 & 714 & 100,0 & 994 & 39 \\
\hline
\end{tabular}

Observações:

(1)* Classes: A - os $1 \%$ de renda mais elevada; B - os $4 \%$ logo abaixo na escala de repartição da renda; C - os $15 \%$ seguintes na escala; D - os $30 \%$ seguintes e E - os $50 \%$ de rendas mais baixas.

(2)* Em milhões de cruzeiros de 1953

(3)* Em cruzeiros de 1953.

FONTES: J. C. Duarte, Aspectos da Distribuição da Renda no Brasil em 1970 (mimeo.), dissertação de mestrado apresentada a ESALQ da USP, 1971.

${ }^{49}$ Op. cit., p. 65.

${ }^{50}$ Paul SINGER, O "Milagre Brasileiro": Causas e Conseqüências, São Paulo, Cebrap, 1972. (mim.) 
Rotatividade, Formação Profissional e Nível de Instrução

Outros elementos que afetam a capacidade de pressão e as orientações dos trabalhadores brasileiros necessitam ser ainda mencionados: a rotatividade no emprego, a formação profissional e o nível escolar. Os trabalhadores brasileiros, em especial as camadas de baixa qualificação, evidenciaram, em todas as pesquisas realizadas, alta rotatividade profissional, passando seguidamente de um emprego para outro, dentro ou fora do sistema industrial. A rotatividade no emprego, não seria preciso ressaltar, dificulta a integração do trabalhador no grupo operário, enfraquece a solidariedade profissional e estimula a busca de soluções individuais, notadamente por parte dos estratos operários dotados de maior qualificação. Por outro lado, a deficiente formação técnica do operário brasileiro, aspecto que está relacionado ao anterior, aumenta o desinteresse pelos assuntos referentes à situação sócio-profissional de trabalho, pois o operário não se sente ligado duradouramente a uma profissão e a seus companheiros. Cumpriria ressaltar, ainda, o baixo nível escolar dos trabalhadores, ponto que é usualmente subestimado, mas que afeta fortemente a capacidade de organização autônoma dos trabalhadores e a possibilidade de emergência de lideranças originadas do próprio meio operário. Os dados disponíveis indicam uma elevada proporção de analfabetos, ou de semiletrados no interior da classe operária brasileiras ${ }^{51}$. A frequência de leituras de jornais é baixa e os trabalhadores são mal informados dos acontecimentos políticos e de outros eventos relacionados à vida nacional. Muitas vezes mal conhecem certos direitos estipulados na Legislação do Trabalho. Sabe-se, por exemplo, que os sindicatos amiúde

\footnotetext{
${ }^{51} \mathrm{Na}$ indústria automobilística estudada em São Paulo, encontramos 6\% de trabalhadores analfabetos e $30 \%$ com primário incompleto (Leôncio Martins RODRIGUES, Industrialização e Atitudes Operárias); a pesquisa com trabalhadores industriais baianos registrou $10,7 \%$ de analfabetos; $27,1 \%$ de semianalfabetos e $28,6 \%$ com primário incompleto. Outra pesquisa sobre a mão de obra na indústria paulista, revelou apenas $1 \%$ de analfabetos e $78 \%$ com curso primário, entre os trabalhadores não especializados. Os dados para estes últimos, não descriminam, entretanto, os que têm curso primário completo e incompleto. É possível, dado os elevados índices de evasão escolar, que parte importante dos operários, considerados com curso primário, de fato não o tenham terminado. Cf. João do Carmo LOPES e José PASTORE, $A$ mão de obra Especializada na Indústria, São Paulo, IPE, 1971. Andréia LOYOLA (op. cit.) encontrou $39 \%$ com curso primário incompleto.
}

alertam aos trabalhadores para não assinar "papéis" apresentados pelos empregadores antes de consultarem os advogados dos sindicatos.

Alguns dos pontos salientados não determinam por si mesmos, e isoladamente, o grau de capacidade reivindicatória dos sindicatos, embora possam influir nas orientações mais gerais da classe, de natureza ideológica ou política. Especificamente, as aspirações de participação nas vantagens da civilização industrial, de integração na sociedade urbana, e as frustrações que daí podem decorrer, pode constituir-se em pontos de apoio para uma política reivindicatória mais agressiva de parte das associações sindicais, enfatizando a ampliação e a diversificação do consumo e outras vantagens sociais. Em outros termos, embora dificultem a emergência de "condutas classistas", poderiam eventualmente levar os sindicatos a uma política reivindicatória que teria alguns pontos de semelhança com a dos sindicatos norte-americanos, ou seja, um tipo de pressão que, embora não contestasse os fundamentos do sistema de poder, a estrutura de classes e os valores fundamentais do sistema social, fosse organizatoriamente autônoma e agressiva.

Outros fatores, no entanto, enfraqueceram a capacidade de barganha dos trabalhadores brasileiros, e, por extensão, de suas associações. O primeiro deles poderia ser resumido no que denominamos de "fraco peso social da classe”. Os trabalhadores industriais, no conjunto da população brasileira, representam parcela minoritária. O crescimento do produto industrial, nos últimos decênios, não aumentou significativamente a importância relativa dos trabalhadores fabris em virtude da tecnologia poupadora de mão de obra. Este fator, apesar de não impossibilitar a formação de sindicatos fortes em determinados setores industriais, reduz a influência geral da classe na sociedade e torna difícil, se não impossível, a formação de partidos operários de alguma expressão eleitoral. Em outros termos, apesar da importância adquirida pela indústria no produto nacional, o peso político e social dos trabalhadores industriais não aumentou na mesma proporção. Dir-se-ia mesmo que diminuiu, em razão da expansão do setor terciário e do aparecimento, no meio urbano, de populações que passaram a pesar - mesmo que passivamente - no sistema de decisões: aumento da importância dos grupos "marginais" nos momentos eleitorais, orientação dos investimentos públicos no sentido da absorção desta mão de obra disponível, etc. 
O segundo fator que reduz a capacidade de barganha, e que no fundo torna os sindicatos dependentes da política governamental, é o excesso de mão de obra à disposição dos empregadores. Nesse sentido, o crescimento urbano efetuou-se em detrimento da força de pressão direta dos sindicatos sobre as empresas. Com exceção de pequenos grupos de trabalhadores, a grande massa operária é de baixa qualificação e facilmente substituível no emprego. Esta é uma situação que perdura há longos anos. O excesso de oferta de mão de obra se iniciou com as grandes migrações de trabalhadores do Nordeste e de outras regiões para as capitais e centros industriais. $\mathrm{Na}$ década de 1930, em São Paulo, completa-se o processo de mudança étnica (e cultural) do proletariado, passando os operários de origem europeia a ser uma minoria no conjunto de mão de obra ${ }^{52}$. Quando a produção fabril se organizava predominantemente com base no chamado sistema profissional de trabalho, a presença de amplo exército industrial de reserva não prejudicava seriamente a capacidade reivindicatória das associações operárias: os trabalhadores de origem rural ou das pequenas cidades do interior que se dirigiam para os grandes centros urbanos, especialmente São Paulo, eram dotados de tão baixa qualificação profissional e educacional, tão pouco socializados para o sistema social e técnico da fábrica que não concorriam com os operários já empregados, geralmente de origem europeia. Porém, quando o sistema de produção em série passou a preponderar, tornando possível o adestramento rápido do trabalhador para a execução de tarefas que não requerem longo aprendizado, o mercado de trabalho passou a evoluir de modo favorável aos empregadores. A heterogeneidade do proletariado nacional aumentou e sua solidariedade interna enfraqueceu-se ante a presença, ao lado dos antigos operários estrangeiros (da Europa Latina, principalmente), de uma massa de trabalhadores vindos de diferentes regiões do país. Ademais, no período compreendido entre 1920-40, a indústria brasileira, em termos de sua capacidade de absorção de mão de obra, cresceu e diversificou-se lentamente ${ }^{53}$, fazendo com que a demanda de emprego

${ }^{52}$ Sobre as migrações de mão de obra ver: José Francisco CAMARGO, Êxodo Rural no Brasil, São Paulo, Faculdade de Ciências Econômicas e Administrativas (USP), 1957. No livro Conflito Industrial e Sindicalismo no Brasil, analisamos mais demoradamente os efeitos das migrações internas sobre as orientações políticas e sindicais do proletariado paulista. Ver a III Parte: "Do Anarquismo ao Nacionalismo: Transformações no Comportamento Operário".

${ }^{53}$ Embora discordando entre si quanto aos efeitos da Primeira-Guerra e da depressão dos anos 30 sobre a economia brasileira, tanto W. BAER (A Industrialização e o Desenvolvimento superasse amplamente a oferta, acentuando a posição desvantajosa dos trabalhadores na barganha com os empregadores.

As mudanças na composição profissional e étnica da classe operária, principalmente em São Paulo, não ocorreram subitamente. Embora seja difícil fixar uma data inicial, todos os dados disponíveis indicam, depois de 1930, o debilitamento progressivo da capacidade reivindicatória autônoma da classe operária, e das formas classistas das condutas e ideologias dos trabalhadores. $\mathrm{O}$ processo de incorporação de novas camadas ao sistema fabril continuou desde então nas condições de forte excesso de oferta de mão de obra, fator essencial que se deve ter em conta para a avaliação da capacidade de pressão da classe operária e consequentemente das táticas a serem utilizadas pelas lideranças.

Econômico no Brasil, Rio, Fundação Getúlio Vargas, 1966), como Warren DEAN (A Industrialização de São Paulo), concordam que a performance da economia brasileira, em termos de capacidade de absorção de mão de obra e de diversificação interna, foi pobre. Tanto econômica como politicamente, nada indica que as mudanças operadas entre 1920-40 tenham sido de molde a incrementar o poder de pressão dos trabalhadores industriais. 


\section{CAPÍtulo IV \\ O Proletariado E A INduSTRIALIZAÇÃo Brasileira}

\section{O Desenvolvimento Econômico: Concentração Industrial e Tecnologia}

Duas características do processo de industrialização no Brasil são particularmente relevantes para a compreensão das orientações e atitudes operárias face ao capitalismo e à sociedade moderna: seu caráter limitado, restrito a algumas áreas do país e o tipo de tecnologia utilizado na expansão fabril das últimas décadas. Apenas esses dois aspectos configuram um quadro social e econômico bastante afastado daquele existente nos países de velha industrialização.

Apesar da extraordinária diversificação do parque fabril nacional e do progresso realizado na substituição de importações, a industrialização brasileira permaneceu restrita a algumas áreas, especialmente ao Estado de São Paulo, onde se originou uma estrutura industrial relativamente complexa e tecnologicamente sofisticada. Não há dúvida que o processo de desenvolvimento mudou o panorama geral da sociedade brasileira, fortalecendo certas camadas sociais, alterando as estruturas anteriores de poder, mudando o estilo de vida e os padrões de consumo de milhões de pessoas. Contudo, o processo de desenvolvimento econômico não destruiu inteiramente a estrutura social e o sistema de poder vigorantes no interior do país e em outras regiões, principalmente do Norte e Nordeste. Uma parcela importante, talvez majoritária da população do país, não se afastou radicalmente dos padrões de consumo e estilo de vida que perduravam há séculos. O caráter limitado da industrialização brasileira ${ }^{1}$ consequentemente, fez com que apenas em algumas áreas surgisse uma classe operária suficientemente importante, concentrada em grandes estabelecimentos. Em termos de concentração operária, apenas São Paulo pode aproximar-se dos grandes centros industriais dos países avançados.

Além disso, quando a industrialização ganhou impulso - a partir da II Guerra mais especificamente, com o surgimento das indústrias de base e de

\footnotetext{
${ }^{1}$ Ver Heinrich RATTNER, Localização da Indústria e Concentração Econômica em São Paulo, São Paulo, Faculdade de Filosofia Ciências e Letras (USP), especialmente Cap. II: "Desequilíbrios Regionais do Desenvolvimento Urbano-Industrial Brasileiro".
}

bens de consumo durável - o modelo de tecnologia utilizado foi aquele existente nos países desenvolvidos. A conjugação desses dois fatores - o caráter limitado da industrialização e o tipo de tecnologia utilizado - fez com que o proletariado fabril - malgrado a importância adquirida pelo setor secundário no PNB - continuasse a representar parcela bastante pequena da força de trabalho.

A participação do emprego industrial em relação à população economicamente ativa passou apenas de 7,86\%, em 1949, para 8,26\% em 1964, enquanto o valor da produção industrial no PIB subia de $19,1 \%$ para $27,3 \%$ nos mesmos anos. A comparação com outros países mostra que a indústria brasileira, em relação ao valor de sua produção, emprega uma proporção bastante pequena da força de trabalho. Na Argentina, para não irmos muito longe, o produto industrial representava $34,0 \%$ do PIB e empregava $25 \%$ da população. Nos EUA, o valor da produção industrial (média 1949-1959) era de 30,3\%, absorvendo 25,6\% do emprego global ${ }^{2}$. Estudo mais recente, indica que no Brasil a tendência do recuo do setor secundário, observada entre 1950-1960, declinou na década de 1960, havendo novamente o crescimento relativo do emprego industrial ${ }^{\text {. }}$. Contudo, o setor que apresenta crescimento constante mais acelerado, é o terciário. Em 1920, o setor terciário absorvia 15,3\% do emprego; em 1940, subiu para 20,0\%; em 1950, para 21,8\%; em 1960 para 23,6\% e, finalmente, em 1969 atingiu 38,0\% ${ }^{4}$.

Ao contrário, portanto, do que sucedeu nos países de velha industrialização, o peso social dos trabalhadores industriais no interior da sociedade brasileira continuou reduzido. As ideologias operárias que vigoraram nos inícios da industrialização europeia alimentavam, em parte, suas esperanças de renovação social no crescimento constante da população

\footnotetext{
${ }^{2}$ Programa Estratégico de Desenvolvimento (1968-70). Estudo Especial: A Industrialização Brasileira: Diagnóstico e Perspectivas. Ministério do Planejamento e Coordenação Geral, 1969. Ver especialmente o Cap. IV: "Participação da Indústria Manufatureira no Produto Interno Bruto e no Emprego. Comparações Internacionais e Produtividade Setorial da Mão de obra".

3 Paul SINGER, Força de Trabalho e Emprego no Brasil: 1920-1969, São Paulo, Cadernos Cebrap $\mathrm{n}^{\circ} 3,1971$. O autor considera que o crescimento da força de trabalho empregada no setor secundário, nos últimos anos "pode ser interpretado como resultado do esgotamento do processo de substituição das unidades artesanais" (p. 56).

${ }^{4}$ Dados extraídos de P. SINGER, op. cit.
} 
fabril. Os partidos operários puderam acreditar, por longos decênios, que a continuação da industrialização levaria ao constante aumento da base social sobre a qual apoiavam sua política e suas esperanças revolucionárias ou reformistas. No Brasil, malgrado o peso social do proletariado fabril nos grandes centros, e sua posição estratégica nos setores dinâmicos da economia nacional, nada evidencia um desenvolvimento semelhante. Pelo contrário. $\mathrm{O}$ setor terciário vem demonstrando maior capacidade de absorção de mão de obra, enquanto se forma, no interior ou nos arredores das grandes cidades, uma população semiempregada, extremamente heterogênea, social e profissionalmente. A perspectiva histórica que parecia abrir-se para os trabalhadores europeus não existe para os trabalhadores fabris brasileiros. Concretamente, pensada a questão em termos políticos, a base social sobre qual se poderia apoiar um partido operário, uniclassista, é extremamente limitada. Quaisquer que sejam as considerações sobre o papel hegemônico do proletariado, os partidos e movimentos que integram as camadas de baixa renda serão essencialmente populares mais do que operários, formados pelas massas pobres do meio urbano que não foram incorporadas ao sistema fabril e que dificilmente o serão. Politicamente, esses setores populares do setor terciário adquirem no contexto brasileiro $-\mathrm{e}$ de outros países subdesenvolvidos - uma importância que não tiveram nos países de velha industrialização. Até o momento, foram espectadores relativamente passivos dos processos de mudanças e das lutas sociais e políticas. Não necessariamente a passividade que demonstraram até o presente precisa continuar. Na cidade, os estímulos para o consumo são mais fortes; certas necessidades elementares de sobrevivência, que no meio rural poderiam ser preenchidas por meio de uma economia de subsistência, não podem ser atendidas do mesmo modo no meio urbano, ao passo que os gastos e despesas, numa economia de mercado, tendem a aumentar. Diluídas as formas de comportamento pautadas pela passividade, pela submissão, pelo respeito e temor ante as camadas altas, essas massas populares (cuja proporção no conjunto da população brasileira é difícil de estimar com exatidão) podem transformar-se em "classes perigosas". Os modos de protesto contra a miséria e as frustrações urbanas, assim como sua extensão, podem variar das explosões de violência coletiva difusa, do banditismo individual à adesão a movimentos religiosos ou políticos de tipo populista.
É difícil de prognosticar com segurança o comportamento e atitudes futuras dessas camadas. Suas aspirações não se cristalizaram até agora em torno de objetivos políticos e sociais claramente definidos e não deram origem a movimentos político-partidários autônomos. Entretanto, sua simples existência cria uma situação de intranquilidade e de ameaça latente para o status quo. Sua heterogeneidade profissional dificulta a emergência de padrões coletivos organizados de conduta. Não estão vinculadas a organizações ou lideranças políticas. São, nesse sentido, "massas politicamente disponíveis". Se não se pode predizer suas orientações futuras, pode-se, no entanto, prever que os elementos catalizadores de suas ações não se localizarão nas estruturas industriais e que os fatores de coesão não serão tampouco de natureza profissional. As questões fabris dificilmente poderão servir de elo de união ou de solidariedade para as camadas marginais.

O tipo de tecnologia e as discrepâncias da expansão industrial, além de reduzirem o peso do proletariado fabril no conjunto das populações pobres, têm ainda outros efeitos sobre a classe operária, mais precisamente sobre suas atitudes com relação ao capitalismo contemporâneo. Na medida em que as condições de vida vigorantes no meio rural persistiram relativamente estáveis durante a industrialização, o emprego fabril representou uma forte atração para as populações pobres das áreas tradicionais, sejam elas a agricultura, a lavoura de subsistência ou as pequenas cidades do interior que oferecem limitadas alternativas profissionais. A incorporação à indústria, nesse contexto, reveste-se de um significado diferente do que teve para os trabalhadores dos países europeus. O prosseguimento da industrialização no Brasil não implicou preponderantemente a "proletarização" de uma pequenaburguesia, de uma camada artesanal ou a ruína de camponeses acomodados. Pelo contrário: significou um processo de ascensão social, de melhoria de status e de nível de vida. Isso não implica, como já acentuamos, que o trabalho industrial em si mesmo, enquanto tarefa, seja estimado positivamente pelos trabalhadores. As pesquisas efetuadas tendem a sugerir o contrário. $\mathrm{Na}$ realidade, o modo de organização do trabalho, de realização das tarefas nas fábricas de produção em massa, não são de natureza a despertar o entusiasmo de ninguém. Tudo indica que o operário valoriza mais o emprego do que a tarefa, em virtude de outras vantagens, tais como salário mais elevado, férias e demais benefícios assegurados pela legislação social. 
No contexto do desenvolvimento brasileiro, os trabalhadores de nível educacional, intelectual e profissional mais elevado - que poderiam constituir as elites operárias sindicalmente ativas - normalmente encontram possibilidades de aperfeiçoamento que lhes possibilitam ascender na empresa ou se estabelecer por conta própria. Nas áreas mais industrializadas, as chances para esse tipo de ascensão não parecem negligenciáveis.

A concentração extrema da indústria em algumas áreas (especialmente no Estado de São Paulo que contribui com cerca de $60 \%$ do valor da transformação industrial do país), tem, ademais dos fatores apontados, o efeito de deprimir a capacidade de reivindicação dos operários. Precisamente em função da concentração da propriedade agrícola, dos baixíssimos níveis de sobrevivência das populações rurais e das escassas oportunidades de emprego nas demais regiões, os "bolsões industriais" atraem grandes levas de migrantes que aumentam a oferta de mão de obra barata. Se essas populações, pelo baixo nível de qualificação profissional e de escolaridade não chegam a afetar seriamente a escala de remuneração dos trabalhadores qualificados, elas tendem a rebaixar os salários dos semiqualificados. (Na realidade, não apenas dos trabalhadores industriais, mas de toda a massa de assalariados manuais das grandes cidades). O desenvolvimento econômico da década dos 50, especialmente a melhoria do sistema de transporte, acentuou essas tendências. Paradoxalmente, a mobilização ${ }^{5}$ das populações rurais, na medida em que não se canalizou preponderantemente para uma pressão sobre as estruturas locais de poder (formação de sindicatos rurais, luta pela legislação social, etc.) e resultou num forte êxodo rural, afetou negativamente a capacidade de barganha dos assalariados urbanos. Até o presente, as conexões entre o setor "arcaico" e o "moderno" agiram em favor da manutenção da estabilidade do sistema social no seu conjunto: as áreas agrárias fornecem mão de obra barata para o parque industrial enquanto os "polos dinâmicos" aliviam as pressões sociais e políticas que a baixa

\footnotetext{
5 O termo "mobilização" é utilizado no sentido do G. Germani, significando o "processo psicossociológico através do qual os grupos submergidos na "passividade" correspondente ao padrão normativo tradicional (predomínio de ação prescritiva através do cumprimento de normas internalizadas) adquirem certa capacidade de comportamento deliberativo, alcançam níveis de aspiração diferentes dos fixados por esse padrão preexistente e, consequentemente, no campo político, chegam a exercer certa atividade", G. GERMANI, Política y Sociedad en una Época de Transición, Buenos Aires, Paidos, 1962, p. 151.
}

produtividade e a escassez de oportunidades poderiam criar nas áreas agrícolas atrasadas. Por outro lado, em virtude do descompasso entre a urbanização e a industrialização, as mudanças operadas na sociedade brasileira nas últimas décadas parecem ter aumentado a importância política e social das classes médias e das camadas populares e diminuído relativamente a dos operários fabris.

\section{A Integração dos Trabalhadores: Autoritarismo e Cultura de Massas}

A crescente participação dos trabalhadores na sociedade industrial (direito de voto, legitimação dos sindicatos, benefícios sociais, ampliação da participação no consumo, etc.) foi um processo que se produziu de diferentes modos nas regiões do mundo que se industrializaram. De modo geral, nos países atualmente desenvolvidos da Europa e da América do Norte, a integração da classe operária na sociedade capitalista resultou de um processo conflitivo que se desenrolou por decênios, no final dos quais as organizações sindicais foram aceitas como representantes autorizadas dos trabalhadores e os partidos operários passaram a participar da "grande política". Na Europa, a mobilização sindical dos trabalhadores precedeu sua participação no sistema político e social formado com a industrialização. Nos Estados Unidos, pelo contrário, os "direitos políticos" precederam os "direitos sindicais" pois, se o direito de votar e ser votado foi desde cedo estendido ao conjunto da população adulta branca e considerado um valor básico da ordem democrática, a legitimação da organização sindical foi bastante posterior. Assim, de modo esquemático, na Europa, os trabalhadores tiveram que lutar tanto pelos direitos sindicais como pelos direitos políticos enquanto, nos Estados Unidos, as principais batalhas da classe operária foram travadas em torno do reconhecimento da organização sindical.

No Brasil, o direito de voto foi concedido muito cedo a toda população, quando da proclamação da República. Mas se tratava de um direito formal que precedeu a mobilização da população assalariada e das camadas pobres. As medidas relacionadas à integração social das massas operárias não estiveram vinculadas a um processo de ampliação democrática do sistema político, mas de seu fechamento ${ }^{6}$. Concretamente, a

6 "O desenvolvimento maciço da população urbana e industrial abalou ou derrubou o sistema político tradicional; as massas urbanas, apoiando os movimentos de natureza autoritária, indiretamente, por seu peso mais do que por sua ação natureza autoritária, indiretamente, por 
outorga de benefícios sociais se realizou por intermédio de um modelo autoritário de poder. A obtenção de vantagens trabalhistas e sociais deu-se à custa da perda dos direitos políticos e da autonomia associativa e reivindicatória dos trabalhadores. A democracia representativa, em especial na Primeira República, foi antes um instrumento de poder e de compromisso entre as diferentes facções oligárquicas.

O proletariado brasileiro não esteve comprometido com a formação das instituições da democracia representativa e não parece, presentemente, que veja nela a via mais adequada para a obtenção de suas reivindicações.

Os resultados de nossa pesquisa com trabalhadores da indústria automobilística ${ }^{7}$, assim como a maciça votação que certos líderes populistas que enfatizavam a autoridade receberam das camadas pobres, sugerem o fraco interesse que os grupos de baixa renda demonstram pelas instituições da democracia representativa. $\mathrm{O}$ estudo com os operários da indústria automobilística indicou uma estreita relação entre baixo nível de qualificação profissional e educacional, de um lado, e preferência por regimes autoritários, de outro lado. Estes eram considerados pelos operários como os mais capazes de elevar o nível de vida do povo e apressar o desenvolvimento nacional. Não se trata, porém, da preferência por qualquer regime autoritário, mas sim por aqueles de cunho populista, capazes de defender os "pobres" contra os "ricos", os "políticos" e os "comerciantes desonestos". Os trabalhadores pensavam, portanto, numa "ditadura popular". Não julgamos que esses resultados reflitam um caso particular. A adesão às instituições da democracia liberal pressuporia, entre outras condições, que as camadas operárias (e as classes populares de um modo geral) fossem suficientemente coesas e organizadas, capazes de atuar autonomamente no plano político e sindical. Pressuporia, sobretudo, que os

seu peso mais do que por sua ação própria, acarretaram o aparecimento de um intervencionismo social do Estado. Esta transformação da sociedade, esta democratização por via autoritária, não se apoia sobre a ação de uma classe; a ação de classe, por definição, repousa sobre a consequência da unidade profunda dos aspectos econômicos, sociais, políticos e culturais da situação de uma categoria social, definida por esta razão como classe". Alain TOURAINE, "Industrialisation et Conscience Ouvrière à São Paulo", Ouvriers et Syndicats d'Amérique Latine, pp. 87-88 (sublinhado por nós).

Leôncio Martins RODRIGUES, Industrialização e Atitudes Operárias, especialmente o cap. IV: "Os Trabalhadores e a Política". sindicatos pudessem se orientar para uma via contratual de relações com a empresa, decorrendo de seus próprios esforços as vantagens eventualmente obtidas por meios conflitivos. Se a classe operária e suas associações não dispõem de força para o enfrentamento direito com o patronato, veem-se constrangidas a esperar ou solicitar do Estado. Os benefícios assim obtidos acarretam necessariamente certo grau de intervencionismo estatal e de paternalismo nas questões trabalhistas. Para uma classe operária de fraca coesão interna e baixo nível de capacidade organizatória, as expectativas de benefícios sociais e elevações salariais dependem fundamentalmente da boa vontade do Estado. Nas condições brasileiras, o regime liberal-democrático favorece os grupos de classe média e alta, dotados de melhores recursos para atuar politicamente e para agir como classe. As esperanças das camadas pobres voltam-se naturalmente para os "regimes fortes", populistas-autoritários, que sejam mais sensíveis às demandas vindas "de baixo", capazes de outorgar vantagens que os trabalhadores por si mesmos, num contexto de luta de classes, não podem conseguir.

Desse modo, se a emergência da classe operária e das camadas urbanas tendeu a criar condições favoráveis para destruição das formas de dominação de tipo agrário-tradicional e dos valores de tipo estamental e elitista, sua participação política não ajudou a afirmação de uma ordem democrática liberal, mas diferentes modalidades de autoritarismo que tendem a se estabelecer, seja como resultado da pressão dos grupos populares, seja como uma reação a ela. Nos dois casos há o reforçamento do poder do Estado, apesar de que, no primeiro, a política estatal seja mobilizadora das camadas populares e, no segundo, desmobilizadora.

$\mathrm{O}$ outro fator relacionado à ausência de condutas classistas entre o proletariado deriva da massificação precoce das áreas urbanizadas e industrializadas da sociedade brasileira. As camadas trabalhadoras adquiriram certo peso social já no momento de predomínio de uma "cultura de massas" divulgada pelos novos meios de comunicação. Não houve tempo para a consolidação de uma "subcultura operária" que marcasse um

${ }^{8}$ Certamente, como acentua Sérgio Micelli, não existe no Brasil uma "cultura de massas" no sentido em que se encontra nos países desenvolvidos, em razão, entre outras, da "inexistência de um mercado simbólico unificado" e da exclusão de uma parte da população de certas formas de consumo. Cf. Sérgio MICELLI, A Noite da Madrinha (Ensaio sobre Indústria Cultural no Brasil), São Paulo, Ed. Perspectiva, 1972. 
estilo de vida e de valores contrapostos ao da cultura dominante. As camadas operárias e de assalariados de baixa renda, ao se incorporarem à indústria ou à vida urbana, passaram de uma situação que poderia ser denominada de cultura tradicional para uma situação de cultura de massas. Esquematicamente, a evolução na Europa poderia ser definida nas seguintes etapas: cultura tradicional - cultura de classes - cultura de massas. No Brasil, o período de "cultura de classe" foi muito curto, e reduzido a São Paulo, em certos grupos operários de origem europeia, geralmente trabalhadores "profissionais", com um tipo de qualificação "artesanal".

Os novos grupos de trabalhadores não elaboraram formas de condutas, estilos de vida e aspirações contrapostas aos padrões socioculturais dominantes. Ao contrário da classe operária europeia dos inícios da industrialização, não procuraram marcar suas diferenças com relação ao modo de vida e à visão do mundo da burguesia ou da pequenaburguesia. As novas massas, que passaram a participar do mundo urbano e fabril, da "sociedade moderna", buscaram predominantemente, quando podiam fazê-lo, imitar os modos de comportamento dos grupos superiores ou da classe média, difundidos pelos meios de comunicação de massas, especialmente pela televisão.

Em razão da concentração da renda, das diferenças educacionais, o abismo entre as "classes ricas" e as "classes baixas" no que tange às oportunidades de consumo, de lazer, etc., é extremamente grande, mesmo nos centros urbanos e industrializados. Desse ângulo, não pode haver nenhuma "homogeneização" social equivalente à que se observa nos países industrialmente avançados.

Porém, o que não se encontra entre as camadas trabalhadoras brasileiras é uma orientação de rejeição dos valores e do estilo de vida dos grupos de alta renda, ou das camadas médias, mas de participação nas formas de vida "superiores" e "modernas". É ilustrativo, nesse sentido, a rapidez com que as massas populares procuram adquirir certos bens que lhes aparecem como símbolos de status, adotam novos modos de trajar, etc.

A maior ou menor capacidade reivindicatória dos trabalhadores não está relacionada à influência dos meios de comunicação e consumo de massas ou à existência de "subculturas" de classes. Ela depende de outras variáveis que examinamos anteriormente, tal como o excesso de mão de obra, a alta rotatividade profissional, etc.. Os efeitos da "massificação" fazem-se sentir de outro modo: no enfraquecimento de formas de condutas "classistas", de ideologias "obreiristas", "antiburguesas", etc..

É possível que nos países desenvolvidos a "sociedade de massas", com seus apelos ao consumo, atenue os anteriores antagonismos de classe. $\mathrm{Na}$ sociedade brasileira, no entanto, tendemos a considerar que tem efeito "mobilizador", no sentido da diluição da passividade tradicional que leva a aceitação de um estado de miséria e submissão. A emergência política e social das massas urbanas e dos trabalhadores fabris vem-se realizando a partir de uma pressão que tem como alvo aspirações de integração e participação nas formas "modernas" de vida; dirige-se antes sobre a "distribuição" do que sobre a "produção". Ao que parece, é a partir da insatisfação da situação como consumidor pobre que os movimentos populistas e operários podem chegar a questionar o modo de acumulação, apropriação e utilização do excedente econômico ${ }^{9}$.

Nos períodos iniciais da industrialização europeia, o movimento sindical apoiou-se sobre uma camada de trabalhadores profissionais, orgulhosos de sua condição de "produtores" e que tentava se defender da expropriação a que eram progressivamente submetidos pelo avanço do capitalismo. As elites operárias não procuraram "igualar-se" aos burgueses, participar de seus estilos de vida. Face aos valores da burguesia e da aristocracia, afirmaram seus próprios valores, em cujo centro estava a sua condição de produtores. A abolição da propriedade privada e a reapropriação dos meios de produção parecia a via mais adequada para a eliminação da miséria e da situação de assalariados. Estes temas, porém, não podem ter o mesmo significado para trabalhadores, como os do Brasil, cujas orientações se fazem no sentido de sua integração num modo de vida urbano-industrial, que partem de um nível de consumo muito baixo e

\footnotetext{
9 “A ênfase posta na economia de consumo induz os vários estratos das diferentes classes sociais a propensões aquisitivas que só poderiam ser satisfeitas através do aumento acelerado da renda nacional e da constante elevação dos níveis de renda real dos assalariados em geral e das classes médias em particular. Como isso não ocorre (nem poderia ocorrer), as contradições surgem e se fortalecem no choque entre níveis de aspiração e poder aquisitivo real ou potencial". Florestan FERNANDES, Sociedade de Classes e Subdesenvolvimento, Rio, Zahar, 1968, p. 51. (Sublinhado no original).
} 
associam a industrialização, independentemente da forma jurídica da propriedade, com o progresso e melhores condições de vida.

\section{O Papel da Agricultura e do Capital Estrangeiro}

Os diferentes estudos sobre a expansão do parque manufatureiro e a formação da sociedade industrial no Brasil são pelo menos convergentes num ponto: o papel secundário desempenhado pela burguesia industrial brasileira, tanto economicamente, no que se relaciona ao fornecimento dos recursos exigidos para a continuidade do desenvolvimento, quanto politicamente, no que se relaciona à criação das condições institucionais necessárias para o crescimento industrial. Nas páginas seguintes, concentraremos a análise em dois aspectos que indiretamente influenciaram as atitudes e orientações dos trabalhadores face ao capitalismo industrial: as origens do capital e dos recursos captados para constituição do sistema fabril e, correlatamente, o papel desempenhado pelos industriais e outros grupos sociais no processo econômico e político.

A constituição das sociedades modernas nos países de antiga industrialização realizou-se lentamente como resultado de um processo de acumulação que pouco a pouco passou a criar os recursos necessários para seu crescimento ${ }^{10}$. Em muitos aspectos, o crescimento industrial brasileiro difere do esquema liberal. Para os fins que nos interessam, são sobressalentes os recursos originados do setor agrícola (lavoura de exportação) e a importância dos recursos externos sob suas diferentes formas (investimentos diretos, empréstimos ao governo, etc.).

A lavoura de exportação e os capitais estrangeiros representaram fontes de financiamento para a acumulação industrial que, nos países de antiga industrialização, não tiveram papel de relevo. É nossa hipótese de que, dadas as características da industrialização brasileira, o aporte de recursos provenientes de fora do setor industrial nacional (em relação com o papel desempenhado pelo Estado e pelo processo inflacionário) permitiu uma rápida acumulação de capital num clima de relativa paz social e industrial. As características do meio rural e do modo de produção aí

\footnotetext{
10 “A expansão de uma empresa quase não colocava problemas porque o aumento da produção podia efetuar-se bastante gradualmente" (...) "O autofinanciamento foi a forma predominante e quase exclusiva do financiamento das empresas no começo do desenvolvimento". Paul BAIROCH, op. cit., pp. 130 e 132.
}

prevalecentes, fornecendo excedentes de mão de obra e de capitais para o setor urbano-industrial, agiram no sentido de atenuar os conflitos entre o capital e o trabalho, que normalmente são bastante violentos nas fases iniciais da industrialização.

No caso brasileiro, nas décadas de implantação das primeiras fábricas, geralmente de iniciativa de imigrantes, grande parte dos recursos, tanto para sua instalação quanto para a posterior ampliação, veio de empréstimos externos, mesmo quando a propriedade pertencia às famílias de imigrantes aqui radicadas. Até a I Guerra, é pouco provável que tenha havido transferência direta de capitais da agricultura para a indústria e que os fazendeiros se tenham transformado em fabricantes. A nascente burguesia industrial, assim como os importadores e comerciantes, eram na imensa maioria imigrantes. O estudo de Luciano Martins, realizado em 1966-67, revela que "exatamente a metade dos grandes industriais (São Paulo e Guanabara) são filhos de pais estrangeiros e $72 \%$ têm avô paterno estrangeiro..."11. Por outro lado, como insiste W. Dean, entre os imigrantes que fizeram fortuna "muitos chegaram com alguma forma de capital: economias de algum negócio realizado na Europa, um estoque de mercadorias, ou a intenção de instalar uma filial de sua firma". E mais adiante: "Há quem suponha que os empreendimentos industriais dos imigrantes tenham sido criados gradualmente pelos reinvestimentos. Com efeito, a maior parte dos fundos originais parece ter provindo de fontes ultramarinas" ${ }^{, 2}$.

O setor agrícola exportador serviu para gerar uma grande massa de renda e criar um mercado consumidor urbano, utilizado progressivamente pelas indústrias que se instalavam no país à medida que se reduzia a capacidade de importar. A transferência de recursos agrícolas para as atividades econômicas urbanas avolumou-se depois da II Guerra, com o confisco cambial que facilitou aos industriais divisas a baixo custo para a aquisição de equipamentos, matérias-primas, etc. ${ }^{13}$.

${ }^{11}$ Luciano MARTINS, Industrialização, Burguesia Nacional e Desenvolvimento, Rio, Ed. Saga, 1968, p. 136

${ }_{12}^{12}$ Warren DEAN, op. cit. pp. 59 e 62 (sublinhado por nós)

${ }^{13}$ A política cambial variou no após-guerra. Após a sangria das divisas acumuladas durante a guerra, os controles cambiais foram restabelecidos em junho de 1947 e mantidos até janeiro de 1953. O cruzeiro foi mantido a Cr\$18,50 por dólar enquanto subiam os preços internos. A Carteira de Exportação e Importação (CEXIM) do Banco do Brasil estabeleceu um 
Trata-se, pois, de um tipo de desenvolvimento que se diferencia do observado nos países em que a indústria teve que criar seus próprios mercados, sem contar com outras fontes de financiamento a não ser aquelas proporcionadas pelos seus próprios lucros.

É difícil estimar a contribuição da agricultura brasileira para o processo de industrialização. Teoricamente, ela pode fazer-se de diferentes maneiras: desvio de lucros agrícolas mediante transferência "voluntária" da atividade econômica, financiamento através da rede bancária, tributação, confisco cambial, etc.. Entre os economistas há divergência com relação ao papel exato da agricultura na acumulação industrial brasileira. W. Baer afirma que a "rede de comercialização se apropria de grande parte da renda que cabe à agricultura e que existe uma tendência de aplicar no setor urbano essa renda captada (muitos capitalistas de hoje começaram como atacadistas). Sabe-se também que os proprietários de terra colocam suas poupanças à disposição do setor industrial; assim, por exemplo, boa parte das primeiras indústrias que se criaram em São Paulo iniciaram sua existência com fundos provindos das poupanças do setor cafeeiro" ${ }^{14}$.

Celso Furtado, analisando os efeitos da crise econômica nos anos de 1930, julga que a crise do mercado mundial e seus reflexos sobre a lavoura cafeeira ocasionou o desvio de parte dos capitais aí aplicados para setores ligados ao mercado interno, apesar de que outros ramos ligados à agricultura de exportação tenham recebido parte desses recursos,

sistema de prioridade nas importações que desencorajava a importação de bens considerados supérfluos. Em janeiro de 1953, o sistema foi tornado mais flexível e em fevereiro do mesmo ano foram criadas três categorias para as exportações. As receitas provindas das exportações tradicionais - café, cacau, algodão, por exemplo - deviam ser convertidas a taxa oficial. Em outubro de 1953, a Instrução 70 da SUMOC e a lei 2.145 estabeleceram o sistema de taxas múltiplas de cambio, introduzindo o sistema de leilões. As importações foram classificadas em cinco categorias e a cada uma delas correspondia uma taxa de cambio. Certas importações foram enquadradas numa categoria preferencial, não participando do sistema de leilões e obtinham cambio à taxa oficial, acrescida de sobretaxas determinada pela SUMOC. Estavam aí incluídos os produtos considerados prioritários para o desenvolvimento, tais como equipamento, petróleo e derivados, papel de imprensa, etc.. De agosto de 1957 a março de 1961, as cinco categorias foram reduzidas a duas: uma "geral" (matérias-primas, bens de capital, trigo, petróleo, etc.) e uma "categoria especial" abrangendo os bens considerados não essenciais. Cf. W. BAER, op. cit., pp. 50 a 59.

${ }^{14}$ Werner BAER, op. cit., p. 125. principalmente a do algodão. Para o período do após-guerra, Celso Furtado considera que não houve transferência de renda da agricultura para a indústria, "pois a relação interna dos preços agrícolas com o índice geral de preços evoluiu favoravelmente à agricultura durante todo o período". Contudo, segundo mesmo autor, o setor industrial apropriou-se de "parte substancial do aumento da renda da coletividade que resultou da melhora na relação de preços do intercambio externo" ${ }^{\text {"15 }}$. Em obra posterior, Celso Furtado afirma, de modo mais explícito, que o setor exportador financiou involuntariamente a expansão industrial ao possibilitar aquisição de equipamento no exterior a baixo preço: "Os recursos para o financiamento das indústrias substituidoras de importações eram, assim, retirados do setor exportador, mediante taxas diferenciais de câmbio, e ao conjunto da população, em consequência da elevação dos preços relativos dos bens cuja oferta estava sendo restringida. Assim, durante essa fase, os exportadores nordestinos (para citar o caso da região onde na época eram quase nulos os investimentos industriais) receberam muito menos cruzeiros pelos dólares gerados pelas suas vendas no exterior, do que eram pagos pelos importadores de bens destinados ao mesmo Nordeste, a fim de que as grandes firmas estrangeiras, como as que. instalaram a indústria automobilística, recebessem subsídio cambial para formar seu capital. Essa situação prolongou-se pela segunda metade dos anos 50 , quando os termos do intercambio se degradaram"16.

Paul Singer considera igualmente que a agricultura subvencionou em diferentes momentos a expansão fabril. " $\mathrm{E}$ significativo constatar que, entre 1932 e 1940, o preço dos alimentos, no Rio, tenha aumentado 53\%, ao passo que o do vestiário aumentou $94 \%$ e o de miscelânea (em geral, produtos industriais) aumentou $179 \%$. Como a expansão industrial relativamente rápida, neste período, deve ter proporcionado baixas de custos graças a ganhos de escala, é de se supor que a margem de lucros tenha se alargado sobremaneira, intensificando-se a acumulação de capital industrial. Não há dúvida, por outro lado, que boa parte do excedente acumulado pela indústria foi produzida pela agricultura e transferida aos empresários industriais, devido à piora das relações de intercambio entre o campo e cidade". Segundo

${ }^{15}$ Celso FURTADO, Formação Econômica do Brasil, Rio, Fundo de Cultura, 1959, p. 256.

${ }^{16}$ Celso FURTADO, Análise do "Modelo" Brasileiro, Rio, Civilização Brasileira, 1972, p. 25 
o autor, a transferência de recursos do setor agrícola exportador para o industrial continuou no após-guerra, graças à ação do Estado.

Esta sangria, que atingiu sobretudo os cafeicultores, não lhes tomou todos os lucros extraordinários pois, (...) no mesmo período, o preço externo do café aumentou de $144 \%$. Deste modo, o preço do café, em cruzeiros deflacionados, ainda eram 34\% mais elevado em $1953 \mathrm{em}$ comparação com 1947. O que se deu, de fato, foi uma divisão dos lucros extraordinários provenientes da alta do café no mercado externo entre exportadores e importadores, isto é, entre empresários do Setor de Mercado Interno ${ }^{17}$.

De outro ponto de vista, Francisco de Oliveira mostra a importância do tipo de relações de produção vigente no setor agropecuário para a acumulação industrial, proporcionando maciços contingentes populacionais (que ampliaram as possibilidades de acumulação industrial) e forneceram "os excedentes alimentícios cujo preço era determinado pelo custo de reprodução da força de trabalho rural..."18.

A. Castro julga que a transferência direta de recursos agrícolas não deve ter sido importante mas não exclui as transferências "não voluntárias", em particular o confisco cambial que, do imediato pós-guerra até 1953, "traduziu-se em vultuosos desvios de recursos em favor da industrialização e contra as culturas de exportação. A partir deste momento, a maioria dos produtos de exportação passam a contar com crescentes 'bonificações' que tendiam a anular, progressivamente, as transferências; o café, porém, continuou transferindo grandes somas até 1958/9"19.

Ainda que seja difícil de estimar o quantum, parece certo que a agricultura de exportação financiou parte da expansão industrial do apósguerra e que, de um modo geral e de diferentes maneiras, contribuiu amplamente para facilitar a acumulação de capital do setor manufatureiro.

Por outro lado, o capital estrangeiro significou outra fonte importante de financiamento. Além dos empréstimos bancários, concedidos diretamente

\footnotetext{
${ }^{17}$ Paul SINGER, O “Milagre Brasileiro": Causas e Conseqüências, p. 19 e 27. (Sublinhado no original).

${ }^{18}$ Francisco OLIVEIRA, op. cit., p. 9 (Sublinhado no original).

${ }^{19}$ Antônio Barros de CASTRO, Sete Ensaios sobre a Economia Brasileira (A Agricultura e Desenvolvimento no Brasil), Rio, Ed. Forense, 1969, p. 135.
}

aos primeiros empresários de origem europeia, o capital estrangeiro esteve presente sob outras diferentes formas, através dos empréstimos aos governos ou de aplicações diretas no setor industrial e, em particular, no de serviços (rede ferroviária, investimentos urbanos, como gás, eletricidade, telefone etc.). A crise dos anos 30 e depois a eclosão da II Guerra provocaram a retração dos investimentos europeus, substituídos pelo afluxo de capital norte-americano. Após a reconstrução do após-guerra, ocorre novamente o retomo do capital europeu (e japonês) que, embora minoritário com relação ao norte-americano, participou ativamente do impulso econômico e das mudanças estruturais que se processaram na indústria brasileira ${ }^{20}$

Certamente, a inflação e a ação estatal não estiveram alheias ao processo de acumulação industrial. Os investimentos diretos do Estado começaram no final do Estado Novo. Antes da guerra, sua ação fora basicamente ordenadora das atividades econômicas ${ }^{21}$ mas, a partir daí, passou a investir diretamente na produção, nos setores que requeriam grande volume e longa maturação de capital. Como assinala Candal, a implantação da Usina de Volta Redonda pode ser considerada como o marco de inflexão da política econômica estatal ${ }^{22}$. Na década de 1950, ampliou-se a participação do Estado, ao lado dos investimentos estrangeiros, quando a economia brasileira passou para uma nova fase de substituição de importações (produção de bens de consumo duráveis e de maior complexidade tecnológica). A criação da Petrobrás e da indústria automobilística são os dois exemplos mais salientes da coexistência, na década de 1950, dos investimentos estatais com as maciças inversões de capital estrangeiro ${ }^{23}$.

A ação do processo inflacionário relaciona-se com a participação crescente do Estado na economia. Segundo Baer, a inflação foi responsável, em boa parte, pela redistribuição de recursos do setor privado para o setor público. Celso Furtado mostra, por outro lado, como através do processo inflacionário e das diferenças entre os preços internos e externos (mediante o controle

${ }^{20}$ Cf. Pinto FERREIRA, Capitais Estrangeiros e Dívida Externa do Brasil, São Paulo, Ed. Brasiliense, 1965

21 Octávio IANNI, Estado e Planejamento Econômico no Brasil (1930-1970), Rio, Civilização Brasileira, 1971

${ }^{22}$ A Industrialização Brasileira: Diagnóstico e Perspectivas.

${ }^{23}$ A participação do setor público na formação de capital fixo, de acordo com W. Baer, passou de $15,8 \%$ em 1947, para 38,2\% em 1950. Op. cit., p. 84. 
cambial), o setor industrial obteve maiores recursos para os reinvestimentos. Para a classe operária, a inflação representou um aumento invisível das poupanças empresariais, menos perceptível do que o "arrocho" salarial.

Não é difícil calcular a participação do capital estrangeiro, do Estado e da agricultura no produto nacional. Mais difícil de estimar é a proporção do crescimento do produto nacional resultante de lucros gerados no interior do próprio setor industrial comparativamente à que se deveu ao aporte externo (agricultura e capital estrangeiro). Pode-se, contudo, afirmar que em comparação com os países de velha industrialização, os lucros obtidos do próprio setor manufatureiro privado nacional desempenharam um papel menos importante no processo de acumulação. O setor secundário nacional era, na verdade, bastante fraco, sem possibilidades de gerar um excedente capaz de sustentar a imensa máquina burocrática, os gastos urbanos, os investimentos de infraestrutura além de financiar seu próprio crescimento mediante contínuas reinversões, de modo a criar, num prazo relativamente curto, uma estrutura industrial diversificada e complexa. Em termos marxistas, dir-se-ia que a mais-valia extraída dos operários industriais, por maior que fosse a exploração do trabalho, não poderia ter sustentado os gastos civis e militares, a construção de uma rede de transporte, o crescimento acelerado da própria indústria, etc.

A presença de fontes externas de financiamento (agricultura e capital estrangeiro), aliada a outros fatores relacionados às características da industrialização substitutiva de importações, não só configuraram um dado modo de formação da sociedade industrial como determinaram outros papéis e pesos políticos para os diferentes grupos sociais. Nesse sentido, uma das consequências dos fatores assinalados foi a redução do período de compressão salarial e de exploração máxima da força de trabalho.

É habitual referir-se às más condições de trabalho e aos baixos salários vigentes na primeiras indústrias brasileiras, especialmente em São Paulo $^{24}$. As instalações fabris eram precárias, o volume de mulheres e

\footnotetext{
${ }^{24}$ Warren Dean chama a atenção para o elevado número de mulheres e menores nas fábricas paulistas e para os baixos salários nas primeiras décadas da industrialização. Porém, na Inglaterra, em 1878, a porcentagem de menores de 13 anos empregados nas indústrias de fiação e tecelagem era de $14 \%$ do total da mão de obra do setor. Para o fim do século (1895)
}

menores empregados era elevado e longas as jornadas de trabalho. Mas não há indicações de que a exploração do trabalho tivesse atingido proporções equivalentes às que marcaram a formação do capitalismo industrial nos países da antiga industrialização. Na Europa, foi necessário aproximadamente um século para que certas vantagens sociais - tais como férias, aposentadoria, descanso semanal remunerado, etc. - fossem estendidas aos trabalhadores. Somente depois de ultrapassadas as fases iniciais de acumulação de capital, quando os aumentos de produtividade passaram a depender mais da utilização do equipamento do que da simples extensão da jornada de trabalho (e aceleração de seu ritmo) é que esta se reduziu para dez horas e depois para oito. No Brasil, em poucos decênios, quando o setor secundário pouco representava no conjunto do sistema econômico (e talvez justamente por isso), as vantagens que os trabalhadores dos países desenvolvidos haviam obtido num processo de luta que durara vários decênios foram outorgadas pelo poder estatal aos assalariados urbanos. Trata-se de entender porque - numa economia que deveria estar em fase de acumulação - o Estado se apressou em elaborar uma legislação social que redundava no encarecimento da força de trabalho. Conviria não ver aí a capacidade de luta do proletariado brasileiro. Nos demais países, malgrado a virulência dos conflitos e a importância do movimento sindical, o patronato resistiu tenazmente à mera redução da jornada de trabalho. Apesar das denúncias no Parlamento, na imprensa liberal e socialista sobre as lamentáveis condições de vida dos trabalhadores (especialmente mineiros e tecelões), o Estado não se apressou a elaborar uma legislação social nem se lançou a uma política de "integração" da classe operária. Ocorre que num tipo de desenvolvimento "voltado para fora", para a conquista de mercados externos, como o europeu, qualquer elevação do preço da força de trabalho que redundasse no encarecimento da produção, diminuía a capacidade de competição das mercadorias exportadas pelos principais países industrializados. Do excedente fornecido pelo setor industrial, provinham os recursos para os reinvestimentos e para os diferentes tipos de gastos da sociedade.

A industrialização brasileira, orientada "para dentro" e contando com outras fontes de recursos, efetuou-se num contexto bastante diferente. Durante a Primeira República, os gastos governamentais eram cobertos em

havia baixado para 5,8\%. Na Bélgica, em 1880, os menores de 16 anos representavam 14\% da força de trabalho industrial. P. BAIROCH, op. cit., p. 135-6. 
grande parte através das tarifas sobre as importações e empréstimos externos. Em última instância, a lavoura de exportação fornecia os recursos, pois tanto as importações como os empréstimos deveriam ser saldados.

De parte dos empresários nacionais, não houve o empenho na conquista agressiva de novos mercados (internos ou externos), através do barateamento dos produtos, da melhoria de sua qualidade, da introdução de técnicas mais racionais de administração e produção, da formação de mão de obra, de pesquisas para a elaboração de novos produtos, etc.. A indústria nacional acomodou-se a um mercado consumidor preexistente, anteriormente abastecido pelo similar estrangeiro.

No após-guerra, especialmente nos anos de 1950, quando a industrialização ganhou novo impulso, o setor industrial não foi obrigado a uma forte e continuada contenção salarial com o fito de aumentar a capitalização e obter maiores excedentes para as reinversões. O capital estrangeiro e a lavoura (especialmente o setor cafeeiro) propiciaram parte dos fundos para a expansão industrial, enquanto o Estado ocupava-se dos investimentos de base e de infraestrutura mediante recursos inflacionários.

Não foi necessário um especial esforço por parte das modernas indústrias no sentido de reduzir os custos derivados dos gastos com salários. Em primeiro lugar, por que eles já não eram elevados; em segundo lugar, porque nas novas indústrias de tecnologia mais complexa, o custo do fator trabalho tende a diminuir em relação aos demais gastos (equipamentos, matérias-primas, etc. ${ }^{25}$; em terceiro lugar, porque se tratava de ramos de elevada produtividade, capazes de proporcionar salários superiores ao nível da média da indústria nacional $^{26}$; e, last but not least, porque a inflação e a situação de monopólio que grande parte das novas fábricas gozavam desde o início, permitia transferir para os consumidores as eventuais "elevações" salariais.

Assim, uma das peculiaridades do desenvolvimento substitutivo de importações, nas condições da estrutura agrícola nacional, foi permitir uma

25 "De 1955 a 1965 o peso relativo dos salários no valor da transformação industrial, passou de 32,9\% a 24,4\%". Wilson CANO, "Industrialização e Absorção de Mão de obra no Brasil”, Indústria e Produtividade, $n^{o}$ 1, junho, 1968. Citado por A. Castro, op. cit. p. 109.

${ }^{26}$ Os setores mais modernos da indústria brasileira operam com uma tecnologia equivalente à dos países desenvolvidos onde os salários são relativamente altos. Porém, a remuneração do trabalho é fixada em grande parte segundo os níveis vigentes no Brasil. elevada taxa de acumulação de capital sem graves conflitos sindicais apesar de os salários operários permanecerem muito abaixo do ritmo de elevação da produtividade do setor industrial ${ }^{27}$ e apesar de ter havido, em determinados períodos, diminuição dos salários reais ${ }^{28}$.

Não se deve inferir do que foi dito que os lucros gerados pelo próprio setor industrial e posteriormente reinvestidos não tivessem desempenhado papel importante na expansão econômica. As empresas estrangeiras, passados os períodos iniciais de sua implantação, remetem lucros para o exterior e podem prosseguir seu crescimento com os ganhos obtidos no mercado nacional. Porém, tanto o setor industrial estrangeiro como o nacional (privado ou estatal), beneficiaram-se, numa escala difícil de ser dimensionada, com os recursos transferidos do setor agrícola, através da rede bancária, do confisco cambial ou dos diferenciais de produtividade ${ }^{29}$. É sintomático como os trabalhadores rurais têm ficado permanentemente à margem de quaisquer benefícios sociais e que nem a burguesia nacional, nem os "governos desenvolvimentistas e populistas" se tenham empenhado em estender a legislação trabalhista ao campo.

Os fatores assinalados explicam, em grande parte, como foi possível a rápida expansão econômica brasileira num clima de relativa "paz industrial". As relações de trabalho vigorantes na agricultura, os recursos proporcionados pela lavoura de exportação, os baixos padrões aquisitivos dos trabalhadores rurais e a ampla oferta de mão de obra contribuíram para

27 “... para a grande parcela de trabalhadores urbanos, a inflação representou uma redistribuição do incremento do produto real em proveito do setor de produção. Isto significa que os trabalhadores não tiveram necessariamente reduzido seu nível de vida mas o aumento deste último não acompanhou o crescimento do produto real". W. BAER, op. cit., p. 124

${ }_{28}$ Segundo Singer, houve queda do salário médio na indústria de São Paulo e Guanabara entre 1949 e 1951. Entre 1952 e 1959, o salário real médio teria passado de 104 para 131. No período compreendido entre 1949 e 1959 o salário real médio teria aumentado de 31\%, enquanto o produto real da indústria teria se elevado de 138,5\%.Paul SINGER, $O$ "Milagre Brasileiro": Causas e Conseqüências.

${ }^{29}$ Na verdade, a contribuição da agricultura - ou dos trabalhadores rurais para a "paz social" no meio industrial pode-se efetuar sem que haja transferências de capitais da agricultura para a indústria. Observa A. Castro que "o declínio dos preços relativos dos alimentos (por exemplo) permite reduções de salários nominais, sem compressão dos salários reais, o que reforça o processo de acumulação fora da agricultura". Antônio B. de CASTRO, op. cit., p. $132($ nota 111$)$. 
propiciar um desenvolvimento industrial no qual a oposição entre o capital e o trabalho foi um fator secundário na modernização das indústrias, na democratização da sociedade e na dinâmica geral da mudança social. Em última instância, os trabalhadores rurais sustentaram a elevação do nível de consumo urbano e, em certa medida, dos operários fabris.

Os salários industriais, na economia nacional, fixaram-se desde cedo em níveis mais elevados do que os vigorantes na agricultura, levando à permanente valorização das ocupações fabris, enquanto os constantes deslocamentos da população rural para os centros urbanos deprimiam a capacidade de reivindicação do proletariado industrial. Instalando-se desde cedo como grandes empresas, contando com um mercado interno protegido, em regime de oligopólio numa economia marcada pela inflação, a indústria teve condições para, ao mesmo tempo, oferecer melhores condições de trabalho e de remuneração às camadas operárias, garantir altas taxas de lucros e evitar um clima de exacerbação dos conflitos.

Não se deve, no entanto, concluir que o tipo de desenvolvimento verificado no país esteja isento de tensões e de "pontos de estrangulamentos". O peso que o café (e outros produtos primários) conserva na balança comercial torna a economia brasileira especialmente vulnerável às oscilações do mercado internacional; as aplicações de capital estrangeiro e suas remessas aumentam a dependência com relação a decisões que são tomadas externamente e sobre as quais o país tem limitados meios de controle; a inexistência de um amplo mercado interno, correspondente ao grau de diversificação atingido pelo parque fabril, cria capacidade ociosa e encarece os preços dos produtos. Do ponto de vista da criação de empregos, o setor industrial expande-se a ritmo inferior ao crescimento demográfico urbano; a aglomeração industrial em algumas poucas cidades e a concentração da renda aumentam a massa de desempregados e da população pobre nas cidades e as desigualdades sociais e regionais. No entanto, os desequilíbrios surgidos com o tipo de industrialização ocorrido no Brasil não se refletem com a mesma intensidade no meio fabril e nem geram um clima de forte insatisfação entre os trabalhadores ${ }^{30}$. Uma singularidade da industrialização brasileira parece

\footnotetext{
30 Assim, é possível que os recursos utilizados para a implantação de uma indústria automobilística na qual os carros de passeio e de luxo ocupam lugar preponderante teriam sido melhor aplicados - do prisma de outros modelos de desenvolvimento - na produção de tratores,
}

ser sua capacidade de deslocar os conflitos e as tensões mais agudas para fora das fronteiras do sistema industrial. As crises políticas de maior envergadura que o país conheceu não foram ocasionadas pelos conflitos trabalhistas, nem o proletariado fabril foi nelas ator de primeiro plano. É significativo, nesse sentido, que em São Paulo onde se concentra quase a metade da indústria do país, os trabalhadores fabris tenham estado praticamente alheios à efervescência nacionalista e reformista dos primeiros anos da década de 1960. É também significativo que as grandes greves operárias que eclodiram no Brasil, deflagradas em São Paulo (1953, 1957, por exemplo) não tenham provocado nenhuma crise política ou institucional. A história de outros países indica que o sistema industrial, principalmente na sua etapa "moderna", demonstra alto grau de flexibilidade e de absorção das pressões sindicais.

A implantação de uma nova unidade fabril, de alta densidade de capital, orientada para o mercado urbano de alta renda, pode desviar recursos de outros setores que produzem para consumo popular. A tecnologia utilizada pode ser de limitada capacidade de absorção de mão de obra. Entretanto, por esses mesmos motivos, os salários aí tenderão a elevar-se acima da média; provavelmente, a empresa cumprirá mais estritamente as obrigações trabalhistas e fornecerá melhores condições de trabalho, além de outras vantagens adicionais (regularidade no pagamento, cooperativa de consumo, etc.). Comparativamente a outros setores de atividade econômica, terá mais recursos para atender as eventuais reivindicações trabalhistas. Em outras palavras: os efeitos negativos de tal tipo de industrialização não se revelam no interior do sistema industrial, mas fora dele. É claro que neste contexto as formas clássicas do conflito ou da luta entre o capital e o trabalho não podem se reproduzir.

Visto de outro ângulo, a importância dos fatores assinalados na expansão econômica (capital estrangeiro, setor exportador e ação do Estado) indicam a fraqueza da burguesia industrial e seu papel comparativamente louco relevante no processo de industrialização. Tal

caminhões, etc.. Porém, tanto para a classe média como para o proletariado, para não falarmos de outros grupos sociais, a instalação e ampliação deste ramo, não foi percebida negativamente, pois novos empregos se abriram com níveis mais elevados de remuneração enquanto a classe média teve acesso a um novo e valorizado bem de consumo. Não haveria motivos para que os trabalhadores industriais reagissem negativamente aos investimentos estrangeiros no setor automobilístico (ou em outros). 
como o proletariado, a burguesia industrial foi incapaz de definir um projeto próprio para a sociedade brasileira. Na realidade, a emergência da ordem industrial no Brasil não decorreu de uma ação de classe do empresariado nacional. Especificamente, face a outros grupos intelectuais, técnicos e militares, seu papel foi secundário na criação das condições institucionais e sociais que favorecessem a consolidação da sociedade industrial. Até a II Guerra, em razão das limitações de suas bases econômicas, de sua composição social e origem ${ }^{31}$, a burguesia industrial foi politicamente caudatária de outros grupos sócio-profissionais ${ }^{32}$. Depois da guerra, quando do novo surto de industrialização, o afluxo de capital estrangeiro e os investimentos estatais ocasionaram o declínio relativo do empresariado nacional. Sob múltiplos aspectos (obtenção de divisas, knowhow, financiamento, proteção contra a concorrência externa, etc.), os empresários brasileiros constituem uma burguesia dependente do Estado ${ }^{33}$, do capital estrangeiro e do setor agroexportador. Na década de 1950, quando o parque industrial se diversificou e se expandiu, os seus setores principais foram controlados pelo Estado e pelas grandes companhias internacionais. Na palavra de F. H. Cardoso, "quando surge a possibilidade estrutural de um projeto burguês de dominação política já não existem possibilidades objetivas de uma economia nacional ${ }^{\text {"34 }}$.

\footnotetext{
31 Observa F. H. Cardoso que "os industriais brasileiros constituem uma camada social recente e heterogênea. Por isso, se no seu conjunto, ainda não reagem como grupo aos problemas com que se defrontam, é preciso considerar que a situação comum de classe é recente e a diversidade dos grupos de origem é grande. Estes fatores dificultam a decantação de modos uniformes de pensar, sentir e agir e dificultam a formação de uma ideologia industrial capaz de nortear a ação de todos em função de interesses comuns". Fernando Henrique CARDOSO, Empresário Industrial e Desenvolvimento Econômico, São Paulo, Difusão Européia do Livro, 1964, p. 161.

32 Em 1930, quando da revolução da Aliança Liberal, os industriais paulistas não tiveram atuação importante. Em 1932, apoiaram o movimento "constitucionalista". "As ligações entre o PRP - sem dúvida, fundamentalmente, o representante dos interesses cafeeiros - e os setores industriais não constituem um acordo ocasional mas uma intima e permanente aliança”. Bóris FAUSTO, A Revolução de 1930, São Paulo, Ed. Brasiliense, 1970, p. 35.

${ }_{33}$ Caio Prado chega a falar de um "capitalismo burocrático" que se "alimenta diretamente da ação estatal e das iniciativas públicas e à custa delas se mantém e progride". Caio PRADO JR., A Revolução Brasileira, São Paulo, Editora Brasiliense, 1966, p. 195.

${ }^{34}$ Fernando Henrique CARDOSO, Política e Desenvolvimento em Sociedades Dependentes, Rio, Zahar, 1971, p. 116 (sublinhado no original).
}

Não se trata de subestimar a importância das camadas empresariais nacionais na política brasileira e sua influência no aparelho de Estado, mas de chamar a atenção para o contexto econômico e social no interior do qual se elaboram determinadas formas de conduta operária. A consciência de classe, as ideologias operárias socialistas, na Europa, definiram-se preponderantemente a partir da rejeição de um tipo de expansão econômica orientada para a acumulação do capital cuja força dirigente e propulsora era a burguesia industrial. Na medida em que essa mesma classe, nos países subdesenvolvidos, é fraca e levada a compartilhar sua posição de classe dirigente com outras forças políticas e grupos sociais (empresas estrangeiras, grandes proprietários, setores militares, etc.), é difícil que o mesmo tipo de consciência de classe "bipolar" possa se reproduzir. A persistência de importantes grupos ligados à agricultura, em especial à lavoura de exportação, cria a base para a emergência de uma consciência "antioligárquica"; a presença do capital estrangeiro pode ocasionar o aparecimento de atitudes nacionalistas, enquanto a influência do Estado na vida econômica e na situação da classe trabalhadora "politiza" as orientações sindicais. Não necessariamente os fatores assinalados devem conduzir ao aparecimento de tendências "nacionalistas" e à politização do proletariado industrial. Constituem, no entanto, marcos de referência na formação de atitudes e modos de comportamento dos trabalhadores industriais, na medida em que são componentes essenciais do quadro social mais amplo no qual a classe está inserida. 


\section{CONCLUSÃO}

\section{PERSPECTIVAS Do SindicAlisMo BRASILEIRO}

Procuramos mostrar, numa exposição sumária da evolução do sindicalismo e do comportamento dos trabalhadores nos diferentes países, que as orientações ideológicas e políticas assim como as formas de ação e de luta do proletariado decorrem da conjunção de muitos fatores. O meio técnico e a forma de propriedade não constituem as únicas variáveis a afetar o comportamento operário, pois, se assim fosse, os valores e os tipos de reivindicações dominantes entre a classe operária seriam aproximadamente os mesmos em toda parte onde o modo de produção capitalista fosse hegemônico. A ideia que orientou o presente trabalho é de que as características predominantes do movimento sindical (ideologias, tipo de organização, atitudes ante o poder político, ante a empresa privada, etc.) dependem, de um lado, do modo concreto de formação da sociedade industrial e, de outro lado, das particularidades do meio pré-industrial, cujo embricamento delimitam as opções operárias, em termos das táticas de luta, enfatizam certos alvos, em termos das motivações ideológicas e determinam o peso social e político da classe, em termos' de sua posição na sociedade.

O Brasil, como outros países que atingiram certo nível de industrialização e modernização, atravessa um período que costuma ser chamado de transição entre uma sociedade agrária e outra urbano-industrial. Trata-se de um período de crise das instituições anteriores e de formação e consolidação de outras mais adaptadas a uma sociedade de base industrial. Os caminhos políticos e institucionais que para aí possam conduzir não estão determinados e, na verdade, nada se pode dizer com segurança se essa transição poderá ser completada, como e quando. Sabemos, contudo, pela própria experiência e pela de outros países, que as fases iniciais de industrialização abrem um período de crise das formas de dominação tradicional (de tipo oligárquico, no caso dos países latino-americanos) e que a institucionalização e consolidação de novas estruturas de poder não se realizam facilmente. O proletariado industrial (como outras camadas sociais) vive este período de "indefinição" política e social, cuja duração parece também indefinida. Trata-se, como procuramos enfatizar, de uma classe que se forma num contexto em muitos aspectos bastante afastado daquele que cercou a formação da classe operária dos países de antiga industrialização. É, pois, muito difícil de prognosticar as orientações políticas e valorativas dessa classe e o tipo de sindicalismo que poderá prevalecer entre nós.

As mudanças políticos-institucionais ocorridas após 1964, e outras de natureza econômica e social que já estavam em gestação (diversificação do parque industrial, ampliação da participação do Estado e do capital estrangeiro na economia brasileira, expansão da urbanização, etc.) alteraram o esquema de forças sociais e políticas até então vigente e, nesse passo, cortaram uma dada evolução do sindicalismo brasileiro.

Parece-nos ocioso insistir no que é evidente: o controle estrito da atividade sindical, o arrocho salarial, a ênfase nos aspectos assistenciais do sindicalismo, etc... Mais importante se nos afigura indagar das alternativas possíveis de orientação dos trabalhadores industriais e do sindicalismo brasileiro. Mas concretamente: em que medida o "colapso do populismo" enquanto sistema político acarretou, correspondentemente, o fim das orientações populistas da massa trabalhadora? Não resta dúvida que o estilo populista de governo desapareceu em 1964. Não resta dúvida também que a participação das lideranças sindicais foi eliminada. Mas difícil de apreciar são as consequências das modificações políticas e institucionais para a atuação dos sindicatos num prazo mais longo.

A estrutura sindical erigida durante o Estado Novo, cujos alicerces permaneceram nos anos que lhe seguiram, possibilitaram, por via burocrática, uma relativa integração dos trabalhadores na sociedade nacional. Em 1964, os canais institucionalizados de comunicação com o Poder, se não foram destruídos, foram ao menos bloqueados, não tanto por iniciativa dos que ocupam os postos de direção nos sindicatos, mas por deliberação governamental. Esse fato, aliado à política de combate à inflação mediante o controle dos salários, e outros mais, parece sugerir a crescente inadequação da presente organização sindical como instrumento reivindicatório dos trabalhadores. Poder-se-ia ir mais além e pensar que abril de 1964 marca a falência de um tipo de orientação política e ideológica que até então tinha predominado entre as direções sindicais. Assim, eliminado o paternalismo 
populista, surgiriam, finalmente, as condições para a emergência de um sindicalismo mais autêntico e reivindicativo.

Embora um prognóstico sobre as reações futuras dos trabalhadores às mudanças políticas ocorridas seja difícil de ser feito, pode-se conjecturar sobre os tipos de movimento sindical e de tendências que, de modo abstrato, encontram maiores probabilidades de emergência. Procedendo por exclusão, a fim de ordenar a discussão, desde já algumas alternativas parecem pouco viáveis.

A reprodução de um sindicalismo semelhante ao que surgiu nos países europeus desenvolvidos, associado a partidos socialistas, necessitaria de um contexto social e econômico relativamente equivalente ao que cercou a industrialização do século passado. Esta hipótese, a nosso ver, está excluída. Um proletariado industrial como o brasileiro, amplamente minoritário no conjunto da população, orientado para a integração na sociedade industrial, não poderia criar um movimento operário do mesmo tipo, o qual seja: grandes partidos socialistas aliados a um sindicalismo sem ligações com setores das camadas superiores.

Por outro lado, a instalação de empresas modernas, a "internacionalização" da economia brasileira, o crescimento do produto nacional, o proclamado fim do paternalismo, o "progresso" enfim, poderiam sugerir que se criariam as condições para o aparecimento de tendências sindicais semelhantes às que vigoram nos EUA, ou seja: um sindicalismo voltado para a melhoria do contrato do trabalho, negociando preferentemente com as empresas e comparativamente pouco crítico com relação ao sistema de poder dominante.

Este tipo de movimento sindical pressuporia uma sociedade influenciada por ideais liberais e competitivos. Economicamente, a condição necessária seria a existência de um capitalismo desenvolvido, dirigido por uma classe empresarial dinâmica, capaz de acarretar o constante crescimento do produto industrial; pressuporia, ademais, a confiança por parte dos sindicatos na capacidade administrativa dos grupos empresariais, de modo a que a ação sindical pudesse se concentrar predominantemente na obtenção de novas vantagens para seus membros sem questionar o modo de gestão e o funcionamento do sistema no seu conjunto.
O sucesso do tipo de sindicalismo que se estabeleceu nos Estados Unidos, orientado para o contrato coletivo de trabalho através de negociações "bipártides" sindicato-empresa, foi possível não só pelo extraordinário dinamismo do capitalismo enquanto sistema econômico, mas também pela estabilidade das instituições da democracia representativa, pelos altos salários que vigoraram desde o início, pela força dos valores liberais, etc.. Pressupor que os sindicatos brasileiros poderiam adotar uma orientação semelhante 'a do sindicalismo americano implicaria também em aceitar a ideia de que o sistema político brasileiro se encaminharia para sua democratização e liberalização crescente. Em poucas palavras: significaria acreditar na possibilidade da consolidação de um sistema político e de um capitalismo privado equiparáveis aos existentes na América do Norte. Ora, não apenas as estruturas políticas e institucionais, as tradições jurídicas e culturais, mas também as bases sociais e econômicas da sociedade brasileira afastam-se inteiramente das existentes nos EUA. Por outro lado, no plano sindical, a emergência de um sistema de relações industriais predominantemente baseado em negociações coletivas que abrangessem amplos aspectos do relacionamento entre empresa e trabalhadores, suporia a diminuição da oferta de mão de obra, um mercado de trabalho organizado e a existência de grupos operários relativamente estáveis no emprego, em posição estratégica para negociar diretamente com as empresas. Essas condições inexistem mesmo na região de São Paulo, ou no eixo industrial São Paulo-Rio. Um conjunto de reivindicações e problemas, que interessam vitalmente os trabalhadores industriais, escapa do plano das relações industriais e só pode ser encaminhado através de medidas governamentais. Pensamos em questões que dizem respeito ao trabalhador enquanto consumidor pobre, tais como moradia, transporte, abertura de novos empregos, escolas, melhoramentos urbanos, etc.. Esses problemas só encontram solução nos quadros de uma política de desenvolvimento global da economia que depende, como procuramos mostrar anteriormente, menos das decisões do capital privado do que da ação governamental, o que inevitavelmente transforma o governo no principal interlocutor dos sindicatos.

Não excluímos, no entanto, que grupos de trabalhadores qualificados, empregados nos setores mais modernos e dinâmicos da economia, inclinemse a negociar diretamente com as suas empresas, fato que poderia dar base de apoio para um sindicalismo mais independente do Estado. Pensamos nas 
camadas operárias cuja qualificação e consciência• profissional possibilitariam formas diretas de pressão sobre as empresas. Tratar-se-ia de trabalhadores cujo mercado de trabalho não lhes seria tão adverso como para a imensa maioria de operários de baixa qualificação. Por sua parte, as grandes e modernas indústrias (multinacionais, na maioria dos casos) poderiam não ser contrárias a uma tal orientação que permitiria o estabelecimento de um sistema de negociações e de relações industriais menos burocratizado, mais flexível e dinâmico, fora dos quadros de uma legislação do trabalho ao mesmo tempo muito geral e rígida, estabelecida para o conjunto dos trabalhadores manuais assalariados. Cumpre notar que a descentralização das negociações, a realização de acordos por empresa e não por ramo industrial é uma tendência que se vem impondo na maior parte dos países industrialmente desenvolvidos. Pode ocorrer, portanto, que grupos operários "modernos", das grandes empresas, sejam tentados a se orientar por uma linha de exclusivismo profissional, a fim de ampliar sua parte nos rendimentos mais elevados das indústrias mais ricas e dinâmicas. Porém, ainda que ocorram pressões sindicais nessa direção e que nos pareça possível que o Estado outorgue maior autonomia às negociações diretas entre grandes empresas e sindicatos, não julgamos que um sistema de relações industriais baseado em efetivas negociações coletivas de trabalho possa tornar-se dominante no Brasil a curto ou a médio prazo. Do lado do Estado, isso significaria abdicar da direção de um aspecto da vida econômica que tem amplas implicações políticas e sociais. $\mathrm{O}$ controle do sindicalismo e do tipo de relacionamento entre empresas e trabalhadores é um dos elementos que vêm configurando a ação estatal no Brasil (e em outros países em processo de desenvolvimento). Do lado da maioria da classe operária brasileira e de outros setores assalariados de baixa qualificação, não pensamos que se possa cristalizar uma orientação no sentido da negociação coletiva de trabalho. Um sistema de relações industriais dessa natureza implicaria que a classe operária se sentisse em condições de enfrentar as grandes empresas em posição de barganha relativamente vantajosa. Nas condições de ampla oferta de mão de obra, de uma classe operária formada em larga medida por trabalhadores que ainda estão em processo de integração ao meio urbano e industrial, a predominância de formas de ação sindical voltadas para o conflito e negociações diretas não parece possível, a não ser para grupos qualificados e minoritários de trabalhadores. Um sistema de relações industriais baseado em negociações coletivas de trabalho requer uma classe empresarial e uma classe operária bem estruturadas e organizadas. Nas condições brasileiras, mesmo o estabelecimento de um sistema "tripártide" envolvendo empresa, sindicato e Estado parece-nos difícil face à esmagadora preponderância do último parceiro.

A maior parte das lideranças sindicais, em nossa opinião, deverá procurar legitimar suas demandas através de uma decisão do Estado, o que implica, em primeiro lugar, não romper totalmente os vínculos com o poder estatal e, em segundo lugar, tentar conseguir governos mais acessíveis às aspirações e demandas dos trabalhadores.

Se um sindicalismo orientado para as negociações coletivas de trabalho, parecido com o norte-americano, também parece não encontrar condições de emergência no meio brasileiro, poder-se-ia pensar no que parece ser o seu polo oposto, isto é, um sindicalismo revolucionário, inspirado em concepções de luta de classes (um pouco ao estilo do sindicalismo francês de antes da I Guerra). Esta hipótese parece ganhar consistência ante o fechamento do sistema político e o controle dos sindicatos oficiais. No entanto, em parte alguma, o sindicalismo - embora possa ser uma força de oposição social - está atualmente movido por concepções revolucionárias negadoras do sistema de salários. As ideologias operárias socialistas ou anarcossindicalista foram o resultado de uma situação particular que marcou a industrialização sob regime liberal. Seu surgimento esteve relacionado à marginalização do proletariado, tanto política como socialmente, nas condições de trabalho e de acumulação capitalista do século passado. Não há nenhuma evidência de que tal situação possa se reproduzir no Brasil, apesar da asfixia do movimento sindical e do fechamento do sistema político.

Uma hipótese não tão extremada seria a da formação de um movimento operário relativamente à margem das estruturas do sindicalismo oficial. Tal alternativa não parece inteiramente inviável. Porém, ela seria mais a reação a uma situação de momento, da impossibilidade da utilização dos mecanismos institucionalizados de desencadeamento e resolução de conflitos. A prazo mais longo, ela não define uma perspectiva, uma linha mais ampla de orientação valorativa. Reações espontâneas de trabalhadores, "greves selvagens" como são habitualmente designadas, podem eclodir em diferentes contextos nacionais, não importa qual seja o tipo de sindicalismo estabelecido e de ideologia operária predominante. Sua ocorrência pode ser 
um índice de descontentamento, de mal-estar social, de revolta. Mas trata-se de uma reação da qual não se pode inferir em tipo de orientação ou uma estratégia geral. No caso brasileiro, ainda que não se possa excluir a ocorrência de explosões desta natureza, cabe perguntar a que modelo de organização sindical e a que tipo de ideologia elas poderão conduzir. Podese pensar o aparecimento de "reações espontâneas" por melhores condições de trabalho, por elevações salariais, visando objetivos a curto prazo. Porém, não se pode pensar a formação de um movimento operário, ou sindical, sem a formação de lideranças, sem ideologias, sem estruturas organizatórias, sem uma tática e uma estratégia. Se assim é, cabe perguntar quais as possibilidades de êxito de tendências operárias à margem das estruturas do sindicalismo oficial? Que chances teriam para a obtenção de vantagens trabalhistas e sociais mais amplas, de consolidação de reivindicações eventualmente obtidas? Em que medida garantiriam para o operário benefícios maiores do que os oferecidos pela legislação trabalhista? Qual seria sua estratégia? Qual seria sua capacidade de pressão? Julgamos que, dependendo de uma série de fatores (entre eles a performance da economia nacional e da ação governamental) a possibilidade de ocorrência de movimentos grevistas, fora dos sindicatos oficiais, não está descartada, embora estes últimos anos tenham mostrado que eles são bem pouco numerosos. Contudo, tais movimentos dificilmente podem dar origem a um movimento sindical fora dos quadros da legislação vigente.

As orientações dos grupos de trabalhadores e a formação de um dado tipo de sindicalismo não decorrem unicamente de modificações de natureza político-institucional, embora elas não sejam destituídas de importância. Mas, na realidade, mudanças institucionais, o comportamento mais "duro" ou "flexível" dos governos com relação à classe operária parecem, quando se atenta para a história do movimento operário, não afetar, a curto prazo, as orientações ideológicas mais profundas da classe operária. Estas últimas estão relacionadas a mudanças sociais básicas que geralmente ocorrem lentamente. De modo mais preciso, as atitudes da classe não são apenas uma resposta a políticas repressivas. Governos mais ou menos sensíveis às reivindicações sindicais ou, pelo contrário, a repressão sistemática, afetam as táticas e os meios de pressão e de luta do sindicalismo, ou da classe no seu conjunto (aumento ou declínio das taxas de greves, do ativismo sindical ou político, da violência nos conflitos, etc.) porém não parecem mudar as orientações valorativas e as ideologias predominantes entre os trabalhadores que decorrem da posição da classe na sociedade, das características do processo de industrialização, dos valores de cada cultura nacional, das mudanças na tecnologia industrial, etc.. As políticas repressivas normalmente aumentam o grau de radicalismo nos conflitos e favorecem as minorias mais agressivas, aumentando seu prestígio no interior da classe em detrimento das correntes mais moderadas. Mas conviria não confundir a radicalização, e mesmo o aumento eventual da violência nos conflitos, com o conteúdo político e valorativo das orientações da classe. Nos Estados Unidos, a intransigência patronal, principalmente das grandes e novas empresas, como no setor automobilístico e do aço, elevou o nível de violência das lutas sindicais, mas não foi suficiente para levar à cristalização de uma consciência socialista entre o proletariado. A legitimação dos sindicatos, o estabelecimento de canais institucionalizados de resolução de conflitos', por outro lado, normalmente agem no sentido do declínio do radicalismo operário, mas seus efeitos em geral são longos e vinculados a outras transformações que ocorrem na sociedade global.

Um prognóstico sobre a evolução futura do sindicalismo brasileiro e do movimento associativo operário (qualquer que seja ele) deve inicialmente considerar alguns fatores cruciais para a análise do comportamento dos trabalhadores. O primeiro deles é o excesso de mão de obra que coloca os operários em posição bastante desvantajosa face às grandes empresas, que reduz sua capacidade de atuação autônoma e os leva a procurar "aliados" e "proteção" em outros grupos e forças sociais, dentro do Estado preferentemente. O segundo é o espírito de mobilidade social e as expectativas de uma maior e melhor participação na sociedade industrial. $O$ terceiro é o papel do Estado, o qual - quaisquer que sejam as alternativas institucionais - deverá ocupar uma posição sobressalente no ritmo e nos rumos do desenvolvimento. Portanto, como agente econômico e como instituição política, o Estado deverá continuar a ser um interlocutor essencial para os sindicatos.

Estabelecidas essas premissas, cabe indagar como os grupos de trabalhadores reagirão a um prolongado cerceamento da atividade sindical e de controle salarial. Nesse caso, falar num aumento do "descontentamento" da classe operária que pode, dependendo da circunstância, externar-se em movimentos grevistas, é vaticinar o óbvio. Porém, a "radicalização" do 
comportamento operário pode dar-se no quadro de orientações valorativas diversas. No caso brasileiro, mais provavelmente, a pressão dos diferentes grupos de trabalhadores far-se-á no sentido, não de uma negação da ordem industrial e do estilo de vida capitalista, mas no de sua participação. Mais concretamente, não terá, como ponto inicial, uma rejeição classista da sociedade. Desse ângulo, as ideologias operárias europeias, como elemento motivacional, não têm condições de sensibilizar os trabalhadores. As aspirações de participação nos modos de consumo e de vida "modernos", como notamos anteriormente, vêm desempenhando fator mais importante na mobilização dos grupos operários. Ao que tudo indica, é nessa direção que se poderá dirigir uma possível pressão operária. O papel dos sindicatos oficiais, na eventualidade de ações reivindicatórias autônomas dos trabalhadores é difícil de antever. Em determinadas ocasiões e circunstâncias é possível que a pressão operária se realize por outras vias, mais diretas, que escapem das direções oficiais e dos canais estabelecidos pelo sindicalismo vigente. Em outras ocasiões, os sindicatos oficiais poderão ser utilizados como canais para a condução de movimentos reivindicatórios "legais". Entretanto, quaisquer que sejam os possíveis desdobramentos da política nacional, não nos parece que seja viável a emergência de um sindicalismo desvinculado do Estado e de um movimento operário independente, isolado de um movimento social e de outras forças políticas mais amplas. A orientação das lideranças operárias, dentro ou fora do sindicalismo oficial, deverá ser no sentido de obter tipos de governos (ou de regimes) mais favoráveis aos trabalhadores, o que pode significar a ampliação do grau de autonomia sindical mas não a desvinculação total com relação ao aparelho estatal. O problema básico, assim, reside no caráter do Estado em relação com o tipo de desenvolvimento.

Se aceitarmos, como parece provável, que certos elementos cruciais para a configuração das orientações operárias, tais como a participação do Estado na economia, as aspirações de participação dos grupos operários e a tecnologia utilizada, não tenderão a curto ou a médio prazo a modificar-se de modo significativo, os tipos seguintes de sindicalismo são teoricamente possíveis:

1. Sindicalismo burocrático-assistencial - O sindicato, estreitamente controlado pelo Estado, preenche funções de desmobilização política e profissional dos trabalhadores. Ocupa-se essencialmente de questões assistenciais e encaminha, por vias burocrático-legais, as reivindicações e queixas dos trabalhadores. Esse tipo de sindicalismo implica, no plano político, um Estado autoritário-burocrático que delimita rigidamente o campo de atuação dos diferentes grupos sociais. No plano econômico, a ação estatal coexiste com a atuação das empresas privadas nacionais e estrangeiras. Embora o Estado regule as atividades econômicas, os mecanismos essenciais que regem o funcionamento do capitalismo privado não são afetados.

2. Sindicalismo populista - O Estado, embora controlando a organização sindical e fixando certas normas para a resolução de conflitos, concede mais autonomia ao sindicalismo. As funções conflitivas do sindicato são parcialmente legitimadas. O quadro econômico que possibilita a emergência desse tipo de sindicalismo pode ser equivalente ao anterior. Politicamente, no entanto, faz-se necessário um Estado de direito, com a vigência dos mecanismos eleitorais da democracia representativa. O Estado não estimula a sindicalização, mas não reprime inteiramente a atividade sindical autônoma desde que essa não ultrapasse certos limites.

3. Sindicalismo nacionalista-desenvolvimentista - O sindicalismo está associado a um Estado controlado por elites nacionalistasdesenvolvimentistas. Persiste a subordinação ao aparelho estatal mas o sindicato cumpre funções mobilizadoras da massa de trabalhadores. Reunido a outros grupos e forças políticas, o sindicalismo integra um movimento nacional de caráter mais amplo e pode servir de instrumento de pressão para vencer a resistência de setores políticos conservadores. Nesse contexto, os sindicatos adquirem maior participação nas decisões e podem constituir-se como uma das bases de sustentação do Poder. Do ponto de vista político, a vigência de um tal tipo de sindicalismo não exclui um Estado autoritário de cunho popular. Porém, ao contrário do primeiro caso, trata-se de um autoritarismo mobilizador das camadas populares. Economicamente, a política de desenvolvimento repousa mais na ação do Estado do que na do capital privado, estrangeiro ou nacional, ainda que o setor privado e a economia de mercado continuem importantes.

4. Sindicalismo socialista-desenvolvimentista - $\mathrm{O}$ sindicalismo continua estreitamente subordinado a um Estado autoritário. Cumpre, conjuntamente, funções mobilizadoras e controladoras da força de trabalho com vistas a um esforço nacional de desenvolvimento. As funções 
reivindicatórias e conflitivas do sindicato passam a segundo plano ou são eliminadas, ocupando-se o sindicato principalmente em auxiliar a reorganização da produção. Esse tipo de sindicalismo só pode ter vigência nos quadros de uma economia cujos principais meios de produção pertencem ao Estado, controlado politicamente por um partido único.

Os tipos de sindicalismo possíveis, "nas condições da sociedade e da classe operária brasileira, decorrem diretamente da natureza do Estado. Dadas as características do proletariado (baixo nível educacional, fraca coesão grupal, etc.) dificilmente um sindicalismo autônomo - qualquer que seja sua ideologia - poderá constituir-se. Por outro lado, a democracia representativa - que permite, em grande medida, os diferentes grupos ou classes sociais digladiarem-se entre si por mais prestígio, poder e consumo - não pode sensibilizar uma classe operária de fraco poder de pressão. A constituição e consolidação de um sindicalismo independente do Estado requer uma identificação ideológica, uma capacidade de organização burocrática e uma coesão interna da classe mais forte do que existem entre o proletariado brasileiro. Ao contrário de outras instituições - como as Forças Armadas, a empresa, etc. - a força do sindicato e sua capacidade de intervenção política dependem fundamentalmente da participação voluntária dos trabalhadores. Na medida em que esta não ocorre de modo persistente e continuado, a legitimidade da organização sindical e das eventuais conquistas operárias necessita ser sancionada pelo poder estatal.

Os laços de identificação grupal formam-se lentamente, em geral num processo de conflitos e de lutas. O tipo de industrialização liberal do passado, quando o proletariado foi deixado a sua própria sorte, constitui o terreno mais propício para a formação de um movimento sindical poderoso. Uma vez formado, o sindicalismo se torna uma instituição fundamental para a posterior evolução das sociedades industriais. Já ressaltamos que o modo de constituição das sociedades modernas é essencial para as suas características posteriores. As instituições que se consolidam nos momentos de formação da sociedade industrial, na medida em que não constituem um obstáculo para a continuidade do industrialismo, tendem a persistir, adaptando-se às ulteriores mudanças sociais. $\mathrm{O}$ ponto de partida do desenvolvimento econômico, isto é, o modo como ele tem início - meio sociocultural pré-industrial, classes ou grupos que impulsionam a industrialização, tipo de organização estatal, etc. - imprime sua marca na sociedade industrial subsequente. Não apenas as características da agricultura - como enfatiza Barrington Moore ${ }^{1}$ - mas de outras instituições e atores sociais como o Estado, tipos de elites, etc., determinam o papel e o peso relativo das diferentes classes e grupos sociais. Os sindicatos, no século passado, formaram-se conjuntamente com o avanço da industrialização burguesa e liberal. Suas lutas e seus valores foram fator importante na democratização do sistema de poder, na modernização industrial, na elevação do nível de participação política e social dos grupos de trabalhadores, etc.. A posterior ampliação do aparelho estatal ocorreu a partir de instituições operárias já consolidadas e poderosas.

No transcorrer de uma industrialização relativamente longa, os sindicatos adquiriram um valor emocional para os trabalhadores $\mathrm{e}$ assumiram funções que os situam, no presente, como um dos pilares essenciais para o equilíbrio e a dinâmica das sociedades desenvolvidas. No Brasil, ainda que no futuro o proletariado venha a aumentar seu peso e influência na sociedade brasileira e afetar de modo mais profundo o processo de mudança social e política, dificilmente poderá ter um papel equivalente ao da classe operária dos países de antiga industrialização.

${ }^{1}$ Barrington MOORE. Social Origins of Dictatorship and Democracy. Boston, Beacon Press, 1966. 


\section{AUTORES CITADOS}

ADAM, G; BON, F.; CAPDEVIELLE, J. e MOURIAUX, R.: L'Ouvrier Français en 1970, Paris, Armand Colin, 1970.

ALBA, Victor: Politics and the Labor Movement in Latin America, California, Stanford University Press, 1968.

ALEXANDER, Robert: Labor Relations in Argentina, Brazil and Chile, Nova York, McGraw-Hill Book, 1962.

ALEXANDER, Robert: A Organização do Trabalho na América Latina, Rio, Civilização Brasileira, 1967.

ANDRIEUX, André e LIGNON, Jean: L'Ouvrier d'Aujourd'hui, Paris, Ed. Gonthier, 1966.

ARON, Raymond: La Lutte de Classes, Paris, Gallimard, 1964.

ASHTON, T. S.: La Revolución Industrial (1760-1830), México, Fondo de Cultura Económica, 1964.

BAER, Werner: A Industrialização e o Desenvolvimento Econômico do Brasil, Rio, Fundação Getúlio Vargas, 1966.

BAILY, Samuel I:. Labor, Nationalism and Politics in Argentina, Nova Jersey, Rutgers University Press, 1967.

BAIROCH, Paul: Revolución Industrial y Subdesarrollo, México, Siglo Veintiuno, 1967.

BALANDIER, Georges e MERCIER, Paul: "El Trabajo en las Regiones en Vias de Industrialización" in: G. Friedmann e P. Naville (eds.): Tratado de Sociologia del Trabajo, México, Fondo de Cultura Económica, $1963,2^{\circ}$ vol.

BARRERA, Manuel: La Participación Social y los Sindicatos en Chile, International Institute for Labor Studies, Genebra, s. d. (mim.)

BASSO, Lelio: "Démocratie et Nouveau Capitalisme", Les Temps Modernes, Paris, setembro-outubro de 1962.
BASSO, Lelio: "Les Perspectives de la Gauche Européenne”, Les Temps Modernes, Paris, fevereiro de 1967.

BERSTEIN, E.: Socialismo Evolucionário, Rio, Zahar, 1964 (14 ed.: 1899).

BOTHÉREAU, Robert: Histoire du Syndicalisme Français, Paris, Presses Universitaire de France, 1946

BOTTOMORE, T. B.: As Classes na Sociedade Moderna, Rio, Zahar, 1968.

BOWEN. H. R. e MANGUN. G. L. (eds.): Automação e Progresso Econômico, Rio, Zahar, 1969.

CAMARGO, José Francisco: Exxodo Rural no Brasil, São Paulo, Faculdade de Ciências Econômicas e Administrativas (USP), 1957.

CANO, Wilson: "Industrialização e Absorção de Mão de obra no Brasil", Indústria e Produtividade, n. ${ }^{\circ}$ 1, junho de 1968.

CARDOSO, Fernando Henrique: Empresário Industrial e Desenvolvimento Econômico, São Paulo, Difusão Européia do Livro, 1964.

CARDOSO, Fernando Henrique e REYNA, José Luiz: "Industrialização, Estrutura Ocupacional e Estratificação Social na América Latina” in: Fernando Henrique Cardoso: Mudanças Sociais na América Latina, São Paulo, Difusão Européia do Livro, 1969.

CARDOSO, Fernando Henrique: Política e Desenvolvimento em Sociedades Dependentes, Rio, Zahar, 1971.

CARVALHO, Inaiá Maria Moreira de: "Operário e Sociedade Industrial na Bahia", Salvador, Estudos Bahianos n. ${ }^{\circ}$ 4. Universidade Federal da Bahia, 1971. CASTRO, Antônio Barros de: Sete Ensaios sobre a Economia Brasileira (A Agricultura e o Desenvolvimento no Brasil), Rio, Ed. Forense, 1969.

CHINOY, Ely: Automobile Workers and the American Dream, Boston, Beacon Press, 1955.

GLEGG, H. A, FOX. A. e THOMPSON, A. F.: A History of British TradeUnion Since 1889, Oxford, Clarendon Press, 1964. 
COLE, G.D.H.: A Short History of the British Working Class, Londres, George Allen and Unwin, 1945.

COLE, G.D.H.: History of the Labour Party from 1914, Londres, George Allen \& Unwin, 1948

COLE, G.D.H.: An Introduction to Trade Unionism, Londres, George Allen \& Unwin, 1943.

COLE, G.D.H.: Historia del Pensamiento Socialista, México, Fondo de Cultura Económica, 1964 (34 ed.) vol. I, "Los Precursores".

COLE, G.D.H.: História del Pensamiento Socialista, México, Fondo de Cultura Económica, 1965 (2 ed.), vols. III e IV "La Segunda Internacional".

COUTTO, Francisco Pedro do: O Voto e o Povo, Rio, Civilização Brasileira, 1966

CROZIER, Michel: "Sociologia del Sindicalismo" in: G. Friedmann e P. Naville (eds.): Tratado de Sociologia del Trabajo, México, Fondo de Cultura Económica, 1963, II Vol. (Tradução brasileira, in: Leôncio Martins Rodrigues (org.), Sindicalismo e Sociedade, São Paulo, Difusão Européia do Livro, 1968.

DAHRENDORF, Ralf: "Politique Syndicale et Structure des Entreprises en Allemagne", Sociologie du Travail, Paris, abril-junho de 1962.

DAVIES, Ioan, African Trade Unions, Londres, Penquin Books, 1966.

DEAN, Warren: A Industrialização de São Paulo, São Paulo, Difusão Européia do Livro, 1971.

DEANE, Phyllis: A Revolução Industrial, Rio Zahar, 1969.

DIAS, Everardo: História das Lutas Sociais no Brasil, São Paulo, Ed. Edaglit, 1962.

DIEBOLD, J.: Automation, the Advent of the Automatic Factory, D. Van Nostrand, 1952.

DI TELLA, Torcuato: El Sistema Político Argentino y la Clase Obrera, Buenos Aires, Eudeba, 1964.
DI TELLA, Torcuato: "Populism and Reform in Latin America" in: Claudio Veliz (ed.), Obstacle to Change in Latin America, Londres, Oxford University Press, 1966 (24 ed.).

DI TELLA, Torcuato; BRAMS, Lucien; REYNAUD, Jean-Luis; e TOURAINE, Alain: Sindicato y Comunidad, Buenos Aires, Editorial del Instituto, 1967.

DOBB, Maurice: A Evolução do Capitalismo, Rio, Zahar, 1963.

DOFNY, Jacques: “Os Sindicatos Americanos e a Automação”, Sociologie du Travail, Paris, julho-setembro de 1961. (Tradução brasileira in: Leôncio Martins Rodrigues (org.), Sindicalismo e Sociedade, São Paulo, Difusão Européia do Livro, 1968.)

DOLLEANS, Édouard e CROZIER, Michel: Mouvements Ouvriers et Socklistes (Chronologie et Biblio,eraphie), Paris, Les Éditions Ouvrières, 1950

DOLLÉANS, Edouard: Histoire du Mouvement Ouvrier, Paris, Librairie Armand Colin, 1953, 3 b vols..

EINZIG, Paul: “Automation et Relations Industrielles", Conséquences Sociales de l'Automation, Bulletin Internacional des Sciences Sociales, UNESCO, vol. X, $\mathrm{n}^{2} 1,1958$.

ENGELS, Frederic: La Situation des Classes Laborieuses en Anglaterre, Paris, Ed. Costes, 1933, ed.: 1845).

ERICKSON, Keneth Paul, Labor in the Political Process in Brazil, 1970 (Tese de doutorado apresentada ao Departamento de Ciências Políticas da Universidade de Columbia, Nova York).

FALLETO, Enzo: "Industrialização e Classe Operária na América Latina", in: Leôncio Martins Rodrigues (org.), Sindicalismo e Sociedade, São Paulo, Difusão Européia do Livro, 1968.

FAUSTO, Bóris: A Revolução de 1930, São Paulo, Ed. Brasiliense, 1970.

FERNANDES, Florestan: Sociedade de Classes e Subdesenvolvimento, Rio, Zahar, 1968. 
FÉRRATON, Hubert: Syndicalisme Ouvrier et Social-Démocracie en Norvege, Paris, Armand Colin, 1960.

FERREIRA, Pinto: Capitais Estrangeiros e Dívida Externa do Brasil, São Paulo, Ed. Brasiliense, 1965.

FOA, Vittorio: "Les Luttes Ouvrières dans le Développement Capitaliste", Les Temps Modernes, Paris, setembro-outubro de 1962.

FOURASTIÉ, Jean: "La Distribuición de la Mano de Obra" in: G. Friedmann e P. Naville (eds.), Tratado de Sociologia del Trabajo, México, Fondo de Cultura Económica, 1963.

FRIEDMANN, G.: Problemas Humanos del Maquinismo Industrial, Buenos Aires, Sudamérica, 1956.

FRIEDMANN, G.: El Trabato Desmenuzado, Buenos Aires, Sudamérica, 1958.

FRIEDMANN, G.: "Tendências de Hoy, Perspectivas de Maiiana" in: G. Friedmann e P. Naville (eds.), Tratado de Sociologia del Trabajo, México, Fondo de Cultura Económica, 1963, II vol.

FRIEDMANN, G.: O Futuro do Trabalho Humano, Lisboa, Moraes Editores, 1968.

FURTADO, Celso: Formação Econômica do Brasil, Rio, Fundo de Cultura, 1959

FURTADO, Celso: Análise do “Modelo" Brasileiro, Rio, Civilização Brasileira, 1972.

GALBRAITH, John: O Novo Estado Industrial, Rio, Civilização Brasileira, 1968.

GALENSON, Walter (ed.): Comparative Labor Movements, Nova York, Prentice-Hall, 1952.

GALENSON, Walter: Trade-Union Democracy in Western Europe, Los Angeles, University of California Press, 1961.

GARAUDY, Roger: A Grande Virada do Socialismo, Rio, Civilização Brasileira, 1970.
GERMANI, Gino: Política y Sociedad en una Época de Transición, Buenos Aires, Paidos, 1962.

GOETZ-GIREU, Robert: La Pensée Syndicale Française, Paris, Armand Colin, 1948.

GOLDTHORPE, John; LOCKWOOD, David; BECHHOFFER, Frank; e PLATT, Jennifer: The Affiuent Worker: Industrial Attitudes and Behaviour, Cambridge University Press, 1968.

GOMPERS, Samuel: Sindicalismo e Trabalhismo nos Estados Unidos. Autobiografia, Rio, Ed. Presença, s. d.

GORZ, André: Stratégie Ouvrière et Néocapitalisme, Paris, Seuil, 1964.

GORZ, André: Le Socialisme Difficil, Paris, Seuil, 1967.

GUÉRIN, Daniel: Anarquismo, Rio, Ed. Germinal, 1968.

GUEST, Robert e WALKER, Charles: The Man on the Assembly Line, Massachussets, Harvard University Press, 1952.

GURRIERI, Adolfo: "Consideraciones sobre los Sindicatos Chilenos", Aportes, Paris, julho de 1968.

GURRIERI, Adolfo: FALETTO, Enzo e RODRIGUES, Leôncio Martins: "Estudo Comparativo do Comportamento Operário no Brasil e no Chile", Sociologia, São Paulo, junho-outubro de 1966.

HARBINSON, Frederick H.: "Egito" in Walter Galenson (ed.) La Clase Obrera y el Desarrollo Económico, México, Editorial Limusa-Wiley, 1964.

HARTMAN. G.: Le Patronat, les Salariés et l'État face à l'Automation, Neuchatel, Ed. de la Baconniere, 1956.

HIRSH-WEBER, Wolfgang: Los Sindicatos en la Política, Madri, Ed. Tecnos, 1964.

HOBSBAWM, E. J.: Labouring Men, Studies in the History of Labour, Nova York, Basic Books, 1964.

HOBSBAWM, E. J.: Rebeldes Primitivos, Rio, Zahar, 1970. 
HUNTINGTON, Samuel: El Ordem Político en las Sociedades en Cambio, Buenos Aires, Paidos, 1972.

IANNI, Octávio: Estado e Planejamento Econômico no Brasil (1930-1970), Rio, Civilização Brasileira, 1971.

ISCARO, Rubens: Origen y Desarrollo del Movimiento Sindical Argentino, Buenos Aires, Ed. Anteo, 1958.

JABET, Julio Cesar: Recabarren, los Origenes del Movimiento Obrero y del Socialismo Chileno, Santiago, Prensa Latinoamericana, 1955.

JONES, G. P.: Workers Abroad, Londres, Thomas Nelson and Sons, 1939.

KERR, Clark e SIEGEL, Abrahan: "The Interindustry Propensity do Strike - An Internacional Comparison" in: R. Dubin; A. Kornhauser e A. Ross (eds.) Industrial Conflict, Nova York, McGraw Hill, 1954.

KERR, C.; DUNLOP. J.; HARBINSON, R e MYERS, Ch.: Industrialismo e Sociedade Industrial, Rio, Fundo de Cultura, 1963.

KNOWLES, K. G. C. J.: Strikes, a Study in Industrial Conflict, Nova York, Philosophical Library, 1952.

LANDSBERGER, Henry: "La Elite Obrera de América Latina y la Revolución" in S. M. Lipset e A. Solari (ecis.): Elites y Desarrollo en América Latina, Buenos Aires, Paidos, 1967.

LAPALOMBARA, Joseph: The Italian Labor Movement: Problems and Prospects, Ithaca, Nova York, Cornel University Press, 1957.

La Situación Sindical en Suecia. Relatório da Organização Internacional do Trabalho, Genebra, 1961.

La Situación Sindical en el Reino Unido. Relatório da Organização Internacional do Trabalho, Genebra, 1961.

LAUBIER, Patrick: "Esquisse d'une Théorie du Syndicalisme", Sociologie du Travail, Paris, outubro-dezembro de 1968.

LESTER, Richard A.: As Union Mature, Nova Jersey, Princeton University Press, 1966 (M ed.).
LILLEY, S.: Automatización y Progreso Social, Madrid, Taurus Ediciones, 1959.

LIPSET, Seymour M. e GORDON, Joan: "Mobility and Trade Union Membership" in: R. Bendix e S. M. Lipset (eds.): Class, Status and Power. The Free Press of Glencoe, 1961, $5^{\mathrm{a}}$ ed.).

LIPSET, Seymour M.: El Hombre Político, Buenos Aires, Eudeba, 1963.

LIPSET, Seymour M.: The First New Nation, Nova York, Anchor Books, 1967, $2^{\mathrm{a}}$ ed.

LOPES, Juarez Rubens Brandão: Sociedade Industrial no Brasil, São Paulo, Difusão Européia do Livro, 1964.

LOPES, Juarez Rubens Brandão: Crise do Brasil Arcaico, São Paulo, Difusão Européia do Livro, 1967.

LOPES, João do Carmo e PASTORE, José: A Mão de obra Especializada na Indústria, São Paulo, IPE, 1971 (mim.).

LOYOLA, Andréia: O Trabalhador Têxtil: Atitudes e Expectativas (Um Estudo de Caso em Minas Gerais), 1972 (dat.).

LOUIS, Paul: Histoire du Socialisme en France (1789-1945), Paris, Marcel Riviere, 1946, (4a ed.).

LUTZ, Burkart: "Les Syndicats Allemands au Début des Années 60", Sociologie du Travail, janeiro-março de 1964. (Tradução brasileira in: Leôncio Martins Rodrigues (org.): Sindicalismo e Sociedade, São Paulo, Difusão Européia do Livro, 1968.

MAGRI, Lúcio: "Le Modele de Développement Capitaliste et le Probleme de l'Alternative Prolétarienne", Les Temps Modernes, n9 196-197, 1962. (Tradução brasileira in: Leôncio Martins Rodrigues (org.): Sindicalismo e Sociedade. São Paulo, Difusão Européia do Livro, 1968).

MALLET, Serge: "Socialism and the New Working Class", International Socialist Journal, ano 2, número 8, abril de 1965.

MALLET, Serge: La Nouvelle Classe Ouvrière, Paris, Seuil, 1969 (2 ${ }^{\mathrm{a}}$ ed.). 
MANDEL, E.: La Réponse Socialiste au Défi Américain, Paris, François Maspero, 1970.

MANN, F. C. e HOFFMAN, L. R.: Automation and the Worker, Nova York, Henry Hold and Co., 1960.

MARCONDES, Freitas: Radiografia da Liderança Sindical Paulista, São Paulo, Instituto Cultural do Trabalho, 1964.

MARJOLIN, Robert: L'Évolution du Syndicalisme aux États-Unis, Paris, Librairie Felix Alcan, 1936.

MARSHALL, T. H.: Cidadania, Classe Social e Status, Rio, Zahar, 1967.

MARTINS, Carlos Estevan: "Integración Social y Mobilización Política en la Clase Baja Urbana del Brasil",Revista Latinoamericana de Ciencia Política, Santiago, abril de 1971.

MARTINS, Luciano: Industrialização, Burguesia Nacional e Desenvolvimento, Rio, Editora Saga, 1968.

MARX, Karl: O 18 Brumário de Luís Bonaparte, Rio, Ed. Vitória, 1956.

MAYNAUD, Jean e SALAH-BEY, Anisse: El Sindicalismo Africano, Madrid, Ed. Tecnos, 1965.

MICELLI, Sérgio: A Noite da Madrinha (Ensaio sobre a Indústria Cultural no Brasil), São Paulo, Ed. Perspectiva, 1972.

MIGLIOLI, Jorge: Como São Feitas as Greves no Brasil, Rio, Civilização Brasileira, 1963.

MILLS, Wright: A Elite do Poder, Rio, Zahar, 1962.

MOMIGLIANO, Franco: Sindicatos, Progreso Técnico, Planificación Económica, Barcelona, Ediciones Península, 1969.

MONTREUIL, Jean: Histoire du Mouvement Ouvrier en France, Paris,. Aubier, 1946.

MORAES FILHO, Evaristo de: O Sindicato Único no Brasil, Rio, Editora "A Noite", 1962.

MOORE, Barrington: Social Origins of Dictatorship and Democracy, Boston, Beacon Press, 1966.
MOTHÉ, Daniel: Militant chez Renault, Paris, Seuil, 1965.

MURMIS, Miguel e PORTANTIERO, Juan Carlos: Estudios sobre los Origenes del Peronismo, Buenos Aires, Siglo XXI Argentina Editores, 1971.

MYERNIK, William A.: Trade-Unions in the Age of Affluence, Nova York, Randon House, 1962, $2^{\mathrm{a}}$ ed.).

NAVILLE, P.: "La Structure de l'Emploi et l'Automation”, Conséquences Sociales de l'Automation, Bulletin International des Sciences Sociales, UNESCO, vol. X., $\mathrm{n}^{\circ} 1,1958$.

NAVILLE, P. e ROLLE, P.: "La Evolución Técnica y sus Repercusiones en la Vida Social" in: G. Friedmann e P. Naville (eds.): Tratado de Sociologia del Trabajo, México, Fondo de Cultura Económica, 1963.

NECOCHEA, Hernan Ramirez: Historia del Movimiento Obrero en Chile, Santiago, Austral.

NEFFA, Julio Cesar: La Participación Interna de los Sindicatos en Argentina, Genebra, International Institute for Labor Studies, s.d. (mim.).

OLIVEIRA, Francisco: A Economia Brasileira: Notas para uma Revista Teórica, São Paulo, Cebrap, 1972 (mim.).

Operário Industrial na Bahia, Salvador, Secretaria do Trabalho e BemEstar Social, 1971.

PARODI, Jeanne: "Les Doutrines Economiques Socialistes et l'Action Syndicale dans le Mouvement Ouvrier Allemand d'Aujourd'hui", Sociologie du Travail, julho-setembro de 1964.

PEREIRA, Luiz: Trabalho e Desenvolvimento no Brasil, São Paulo, Difusão Européia do Livro, 1965.

PELLING, Henry: El Sindicalismo Norteamericano, Madrid, Tecnos, 1961.

PELLING, Henry: A Short History of the Labour Party, Londres, MacMillan 1968, ed.).

PERLMAN, Selig: A Theory of the Labor Movement, Nova York, August M. Kelley, 1949 (1 ${ }^{\mathrm{a}}$ ed.: 1928). 
PETERSON, Florence: Sindicatos Operários Norte-Americanos, Rio, Agir, 1953.

PHILIP, André: Trade Unionisme et Syndicalisme, Paris, Fermand Aubier, 1936.

POLLOCK, F.: La Automación: sus Consecuencias Econômicas y Sociales, Buenos Aires, Sudamérica, 1959.

PRADO JR., Caio: A Revolução Brasileira, São Paulo, Ed. Brasiliense, 1970.

RABELlO, Ophélia: A Rede Sindical Paulista, Instituto Cultural do Trabalho, 1965.

RAFFAELE, Joseph: Labor Leadership in Italy and Denmark, Madinson, The University of Wisconsin Press, 1962.

RANGEL FILHO, Cassiano Marcondes e TAVARES, Maria Herminia: Nacionalismo e Greve, São Paulo, s. d. (dat.).

RATTNER, Heinrich: Localização da Indústria e Concentração Econômica em São Paulo, Faculdade de Filosofia, Ciências e Letras (USP), 1968 (mim.).

RAYBACK, Joseph: A History of American Labor, Nova York, The MacMillan, 1959.

REYNOLDS, Lloyd: Economia Laboral y Relaciones de Trabajo, México, Fondo de Cultura Económica, 1964.

RODRIGUES, José Albertino: Sindicato e Desenvolvimento no Brasil, São Paulo, Difusão Européia do Livro, 1968.

RODRIGUES, Leôncio Martins: Conflito Industrial e Sindicalismo no Brasil, São Paulo, Difusão Européia do Livro, 1966.

RODRIGUES Leôncio Martins (org.): Sindicalismo e Sociedade, São Paulo, Difusão Européia do Livro, 1968.

RODRIGUES, Leôncio Martins: Industrialização e Atitudes Operárias, São Paulo Ed. Brasiliense, 1970.
RODRIGUES, Leôncio Martins: "O Sindicalismo e os Trabalhadores Industriais no Brasil: Notas para um esquema explicativo". Cadernos, $\mathrm{n}^{\mathrm{o}}$ 4. Centro de Estudos Rurais e Urbanos, São Paulo, 1971.

ROSS, Arthur: "Les Relations Professionnelles aux États-Unis dans les Dix Années a Venir", Sociologie du Travail, Paris, abril-junho de 1962.

ROSTOW, Walt: Etapas do Desenvolvimento Econômico, Rio, Zahar, 1961.

SAVILLE, John: "Trade Unions and Free Labour: The Background to the Taft Vale Decision", in: Asa Briggs e John Saville (eds.): Essays in Labour History. Londres, MacMillan, 1967 (2ªd.).

SCHMITTER, Philip: Interest Conflict and Political Change in Brazil, Stanford University Press, 1971.

SHONFIELD, Andrew: Capitalismo Moderno, Rio, Zahar, 1968.

SIMÃO, Azis: “O Voto Operário em São Paulo”, Anais do 1 Congresso Brasileiro de Sociologia, São Paulo, Sociedade Brasileira de Sociologia, 1955.

SIMÃO, Azis: "Industrialisation et Syndicalisme au Brésil", Ouvriers et Syndicats d'Amérique Latine, número especial da revista Sociologie du Travail, Paris, n. ${ }^{\circ} 4,1961$.

SIMÃO, Azis: Sindicato e Estado, São Paulo, Dominus Editora, 1966.

SINGER, Paul: Força de Trabalho e Emprego no Brasil: 1920-1969, São Paulo, Cadernos Cebrap n ${ }^{\circ}$ 3, 1971.

SINGER, Paul: O “Milagre Brasileiro”: Causas e Conseqüências, São Paulo, Cebrap, 1972 (mim.).

SOARES, Gláucio Dillon: “Classes Sociais e Eleições Presidenciais de 1960” Sociologia, São Paulo, setembro de 1961.

SOARES, Gláucio Dillon: “Alianças e Coligações Eleitorais”, Revista Brasileira de Estudos Políticos, Belo Horizonte, julho de 1964.

SOARES, Gláucio D.: “A Nova Industrialização e o Sistema Político Brasileiro”, Dados, no 2/3, 1967. 
STURMTHAL, Adolf: The Tragedy of European Labor (1918-1939), Londres, Victor Gollancz, 1944.

STURMTHAL, Adolf (ed.): White-Collar Trade-Unions, Chicago, University of Illinois, 1967.

TAFT, Philip: A Federação Americana do Trabalho, Rio, Distribuidora Record, 1965, II vol.

TAYLOR, Frederic W.: Princípios de Administração Científica, São Paulo, Atlas, 1966 (1.9 ed.: 1911).

THOMPSON, E. P.: The Making of the English Working Class, Londres, Pelican Books, 1968.

TOURAINE, Alain e RAGAZZI, Orietta: Ouvriers d'Origine Agricole, Paris, Seuil, 1961

TOURAINE, Alain: "Industrialisation et Conscience Ouvriere à São Paulo", Ouvriers et Syndicats d'Amerique Latine, número especial da Sociologie du Travail, Paris, n. ${ }^{\circ} 4,1961$.

TOURAINE, Alain e MOTTEZ, Bernard: "Clase Obrera y Sociedad Global" in: G. Friedmann e P. Naville (eds.): Tratado de Sociologia del Trabajo, México, Fondo de Cultura Económica, 1963, II vol. (Tradução brasileira in: Leôncio Martins Rodrigues (org.): Sindicalismo e Sociedade, São Paulo, Difusão Européia do Livro, 1968.

TOURAINE, Alain: "La Organización Profesional de la Empresa" in: G. Friedmann e P. Naville (eds.): Tratado de Sociologia del Trabajo, México, Fondo de Cultura Económica, 1963, II vols.

TOURAINE, Alain: La Conscience Ouvrière, Paris, Seuil, 1966.

TOURAINE, Alain: La Société Post-Industrielle, Paris, 1969.

TRÉATON, Jean René: "Los Conflictos del Trabajo" in: G. Friedmann e P. Naville (eds.): Tratado de Sociologia del Trabajo, México, Fondo de Cultura Económica, 1963.
TRENTIN, Bruno: "Tendances Actuelles de La Lutte de Classes et Problemes du Mouvement Syndical", Les Temps Modernes, Paris, fevereiro de 1967.

TRENTIN, Bruno: "Les Syndicats Italiens et le Progrés Technique", Sociologie du Travail, Paris, abril-junho de 1962 (Tradução brasileira in: Leôncio Martins Rodrigues (org.): Sindicalismo e Sociedade, São Paulo, Difusão Européia do Livro, 1968).

VIANNA, Oliveira: Problemas do Direito Corporativo, São Paulo, José Olympio, 1938.

VIANNA, Oliveira: Problemas do Direito Sindical, Rio, Ed. Max Limonad, 1943.

VIANNA, Oliveira: Direito do Trabalho e Democracia Social, São Paulo, José Olympio, 1951.

WALINE, Pierre: Les Syndicats aux États-Unis, Paris, Armand Colin, 1951.

WEBB, Sidney e Beatrice: The History of Trade Unionism, Londres, Longmans Green and Co., 1950 (1 $1^{\mathrm{a}}$ ed.: 1894).

WEFFORT, Francisco C.: "Estado y Masas en el Brasil", Revista Latinoamericana de Sociologia, Buenos Aires, março de 1965.

WEFFORT, Francisco C.: "Raízes Sociais do Populismo em São Paulo", Revista Civilização Brasileira, Rio, maio de 1965.

WEFFORT, Francisco C.: Classes Populares e Políticas (Contribuição ao Estudo do Populismo), São Paulo, Faculdade de Filosofia, Ciências e Letras, 1968 (mim.).

WEFFORT, Francisco C.: Participação e Conflito Industrial: Contagem e Osasco - 1968, São Paulo, Cadernos Cebrap n ${ }^{\circ}$ 5, 1972.

ZAPATA, Francisco: Federaciones Centrales en el Sindicalismo Chileno, Genebra. Internacional Institute for Labor Studies, s. d. (mim.). 